Cochrane Database of Systematic Reviews

\title{
Black cohosh (Cimicifuga spp.) for menopausal symptoms (Review)
}

Leach MJ, Moore V

Leach MJ, Moore V.

Black cohosh (Cimicifuga spp.) for menopausal symptoms.

Cochrane Database of Systematic Reviews 2012, Issue 9. Art. No.: CD007244.

DOI: 10.1002/14651858.CD007244.pub2.

www.cochranelibrary.com 
TABLE OF CONTENTS

HEADER

ABSTRACT

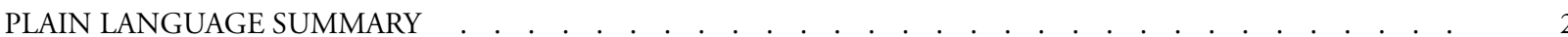

SUMMARY OF FINDINGS FOR THE MAIN COMPARISON . . . . . . . . . . . . . . . . . . . 3

BACKGROUND . . . . . . . . . . . . . . . . . . . . . . . . . . . . . . . . . . . 6

OBJECTIVES . . . . . . . . . . . . . . . . . . . . . . . . . . . . . . . . . . . 7

METHODS . . . . . . . . . . . . . . . . . . . . . . . . . . . . . 7

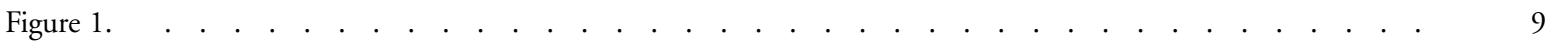

RESULTS . . . . . . . . . . . . . . . . . . . . . . . . . . 11

Figure 2. . . . . . . . . . . . . . . . . . . . . . . . . . . . . . . . . . . . . . 13

Figure 3. . . . . . . . . . . . . . . . . . . . . . . . . . . . . . . . . . . . . . 14

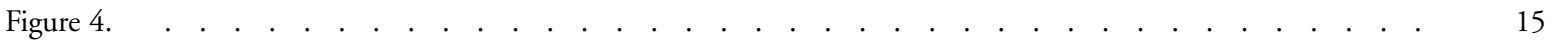

Figure 5. . . . . . . . . . . . . . . . . . . . . . . . . 16

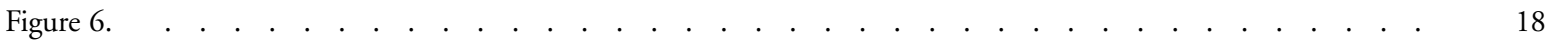

DISCUSSION . . . . . . . . . . . . . . . . . . . . . . . . . . 20

AUTHORS' CONCLUSIONS . . . . . . . . . . . . . . . . . . . . . . . . . . . . . . . 21

ACKNOWLEDGEMENTS . . . . . . . . . . . . . . . . . . . . . . . . . . . . . . . . 21

REFERENCES . . . . . . . . . . . . . . . . . . . . . . . . . 22

CHARACTERISTICS OF STUDIES . . . . . . . . . . . . . . . . . . . . . . . . . . . . . . . . . . . . . . 24

DATA AND ANALYSES . . . . . . . . . . . . . . . . . . . . . . . . . . . . . . . . . . . . . . . . . . 55

Analysis 1.1. Comparison 1 Black cohosh versus placebo, Outcome 1 Vasomotor symptoms: daily hot flush frequency. $\quad 56$

Analysis 1.2. Comparison 1 Black cohosh versus placebo, Outcome 2 Vasomotor symptoms: weekly hot flush frequency. 57

Analysis 1.3. Comparison 1 Black cohosh versus placebo, Outcome 3 Vasomotor symptoms: hot flush intensity. . . $\quad 58$

Analysis 1.4. Comparison 1 Black cohosh versus placebo, Outcome 4 Vasomotor symptoms: night sweats. . . . . . 58

Analysis 1.5. Comparison 1 Black cohosh versus placebo, Outcome 5 Menopausal Symptom Score. . . . . . . . 59

Analysis 1.6. Comparison 1 Black cohosh versus placebo, Outcome 6 Adverse events. . . . . . . . . . . . . . 60

Analysis 2.1. Comparison 2 Black cohosh versus hormone therapy, Outcome 1 Vasomotor symptoms: daily hot flush frequency.

Analysis 2.2. Comparison 2 Black cohosh versus hormone therapy, Outcome 2 Vasomotor symptoms: weekly hot flush frequency.

Analysis 2.3. Comparison 2 Black cohosh versus hormone therapy, Outcome 3 Vasomotor symptoms: hot flush intensity. Analysis 2.4. Comparison 2 Black cohosh versus hormone therapy, Outcome 4 Vasomotor symptoms: night sweats. . Analysis 2.5. Comparison 2 Black cohosh versus hormone therapy, Outcome 5 Menopausal Symptom Score. . . . Analysis 2.6. Comparison 2 Black cohosh versus hormone therapy, Outcome 6 Adverse events. . . . . . . . . . . Analysis 3.1. Comparison 3 Black cohosh versus red clover, Outcome 1 Vasomotor symptoms: hot flush frequency. Analysis 3.2. Comparison 3 Black cohosh versus red clover, Outcome 2 Vasomotor symptoms: hot flush intensity. Analysis 3.3. Comparison 3 Black cohosh versus red clover, Outcome 3 Menopausal score. Analysis 4.1. Comparison 4 Black cohosh versus fluoxetine, Outcome 1 Vasomotor symptoms: night sweats. . . . . 66 Analysis 4.2. Comparison 4 Black cohosh versus fluoxetine, Outcome 2 Menopausal score. . . . . . . . . . . . 66

ADDITIONAL TABLES . . . . . . . . . . . . . . . . . . . . . . . . . . . . . . . . . . . . 66

APPENDICES . . . . . . . . . . . . . . . . . . . . . . . . . . . . . . . . . . . . . . . 88

HISTORY . . . . . . . . . . . . . . . . . . . . . . . . . . . . . . . . . . . . . . . 99

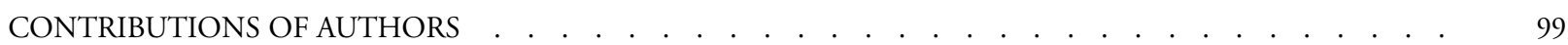

DECLARATIONS OF INTEREST ．．．．．．．．．．．．．．．．．．．．．．．．．．．．．．． . 999

SOURCES OF SUPPORT ．．．．．．．．．．．．．．．．．．．．．．．．．．．．．．．．．．．． . 999

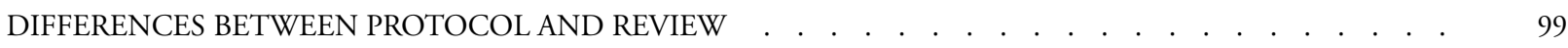

INDEX TERMS . . . . . . . . . . . . . . . . . . . . . . . . . . . . . . . . . . . . . . . 99

Black cohosh (Cimicifuga spp.) for menopausal symptoms (Review)

Copyright ( 2012 The Cochrane Collaboration. Published by John Wiley \& Sons, Ltd. 
[Intervention Review]

\title{
Black cohosh (Cimicifuga spp.) for menopausal symptoms
}

\author{
Matthew J Leach ${ }^{1}$, Vivienne Moore ${ }^{2}$ \\ ${ }^{1}$ School of Nursing \& Midwifery, University of South Australia, Adelaide, Australia. ${ }^{2}$ Department of Public Health, University of \\ Adelaide, Adelaide, Australia
}

Contact address: Matthew J Leach, School of Nursing \& Midwifery, University of South Australia, North Terrace, Adelaide, South Australia, 5000, Australia. Matthew.leach@unisa.edu.au.

Editorial group: Cochrane Gynaecology and Fertility Group.

Publication status and date: Edited (no change to conclusions), published in Issue 10, 2012.

Citation: Leach MJ, Moore V. Black cohosh (Cimicifuga spp.) for menopausal symptoms. Cochrane Database of Systematic Reviews 2012, Issue 9. Art. No.: CD007244. DOI: 10.1002/14651858.CD007244.pub2.

Copyright (C) 2012 The Cochrane Collaboration. Published by John Wiley \& Sons, Ltd.

\begin{abstract}
A B S T R A C T
Background

Menopause can be a distressing and disruptive time for many women, with many experiencing hot flushes, night sweats, vaginal atrophy and dryness. Postmenopausal women are also at increased risk of osteoporosis. Interventions that decrease the severity and frequency of these menopausal symptoms are likely to improve a woman's well-being and quality of life. Hormone therapy has been shown to be effective in controlling the symptoms of menopause; however, many potentially serious adverse effects have been associated with this treatment. Evidence from experimental studies suggests that black cohosh may be a biologically plausible alternative treatment for menopause; even so, findings from studies investigating the clinical effectiveness of black cohosh have, to date, been inconsistent.
\end{abstract}

\section{Objectives}

To evaluate the clinical effectiveness and safety of black cohosh (Cimicifuga racemosa or Actaea racemosa) for treating menopausal symptoms in perimenopausal and postmenopausal women.

\section{Search methods}

Relevant studies were identified through AARP Ageline, AMED, AMI, BioMed Central gateway, CAM on PubMed, CINAHL, CENTRAL, EMBASE, Health Source Nursing/Academic edition, International Pharmaceutical Abstracts, MEDLINE, Natural medicines comprehensive database, PsycINFO, TRIP database, clinical trial registers and the reference lists of included trials; up to March 2012. Content experts and manufacturers of black cohosh extracts were also contacted.

\section{Selection criteria}

All randomised controlled trials comparing orally administered monopreparations of black cohosh to placebo or active medication in perimenopausal and postmenopausal women.

\section{Data collection and analysis}

Two review authors independently selected trials, extracted data and completed the 'Risk of bias' assessment. Study authors were contacted for missing information.

Black cohosh (Cimicifuga spp.) for menopausal symptoms (Review)

Copyright ( 2012 The Cochrane Collaboration. Published by John Wiley \& Sons, Ltd. 


\section{Main results}

Sixteen randomised controlled trials, recruiting a total of 2027 perimenopausal or postmenopausal women, were identified. All studies used oral monopreparations of black cohosh at a median daily dose of $40 \mathrm{mg}$, for a mean duration of 23 weeks. Comparator interventions included placebo, hormone therapy, red clover and fluoxetine. Reported outcomes included vasomotor symptoms, vulvovaginal symptoms, menopausal symptom scores and adverse effects. There was no significant difference between black cohosh and placebo in the frequency of hot flushes (mean difference (MD) 0.07 flushes per day; $95 \%$ confidence interval (CI) -0.43 to 0.56 flushes per day; $\mathrm{P}=0.79$; 393 women; three trials; moderate heterogeneity: $\mathrm{I}^{2}=47 \%$ ) or in menopausal symptom scores (standardised mean difference (SMD) $-0.10 ; 95 \%$ CI -0.32 to $0.11 ; \mathrm{P}=0.34 ; 357$ women; four trials; low heterogeneity: $\mathrm{I}^{2}=21 \%$ ). Compared to black cohosh, hormone therapy significantly reduced daily hot flush frequency (three trials; data not pooled) and menopausal symptom scores (SMD 0.32; $95 \%$ CI 0.13 to $0.51 ; \mathrm{P}=0.0009 ; 468$ women; five trials; substantial heterogeneity: $\mathrm{I}^{2}=69 \%$ ). These findings should be interpreted with caution given the heterogeneity between studies. Comparisons of the effectiveness of black cohosh and other interventions were either inconclusive (because of considerable heterogeneity or an insufficient number of studies) or not statistically significant. Similarly, evidence on the safety of black cohosh was inconclusive, owing to poor reporting. There were insufficient data to pool results for healthrelated quality of life, sexuality, bone health, vulvovaginal atrophic symptoms and night sweats. No trials reported cost-effectiveness data. The quality of included trials was generally unclear, owing to inadequate reporting.

\section{Authors' conclusions}

There is currently insufficient evidence to support the use of black cohosh for menopausal symptoms. However, there is adequate justification for conducting further studies in this area. The uncertain quality of identified trials highlights the need for improved reporting of study methods, particularly with regards to allocation concealment and the handling of incomplete outcome data. The effect of black cohosh on other important outcomes, such as health-related quality of life, sexuality, bone health, night sweats and costeffectiveness also warrants further investigation.

\section{PLAIN LANGUAGESUMMARY}

\section{Black cohosh (Cimicifuga spp.) for menopausal symptoms}

Menopause is the period of time in a woman's life when menstruation ceases. These changes in menstruation are often accompanied by troublesome symptoms, including hot flushes, vaginal dryness and night sweats. Interventions that decrease the severity and frequency of these menopausal symptoms are likely to improve a person's well-being and quality of life. The herb black cohosh was traditionally used by Native Americans to treat menstrual irregularity, with many experimental studies indicating a possible use for black cohosh in menopause. This review set out to evaluate the effectiveness of black cohosh for controlling the symptoms of menopause. The review of 16 studies (involving 2027 women) found insufficient evidence to support the use of black cohosh for menopausal symptoms. Given the uncertain quality of most studies included in the review, further research investigating the effectiveness of black cohosh for menopausal symptoms is warranted. Such trials need to give greater consideration to the use of other important outcomes (such as quality of life, bone health, night sweats and cost-effectiveness), stringent study design and the quality reporting of study methods.

Black cohosh (Cimicifuga spp.) for menopausal symptoms (Review) 


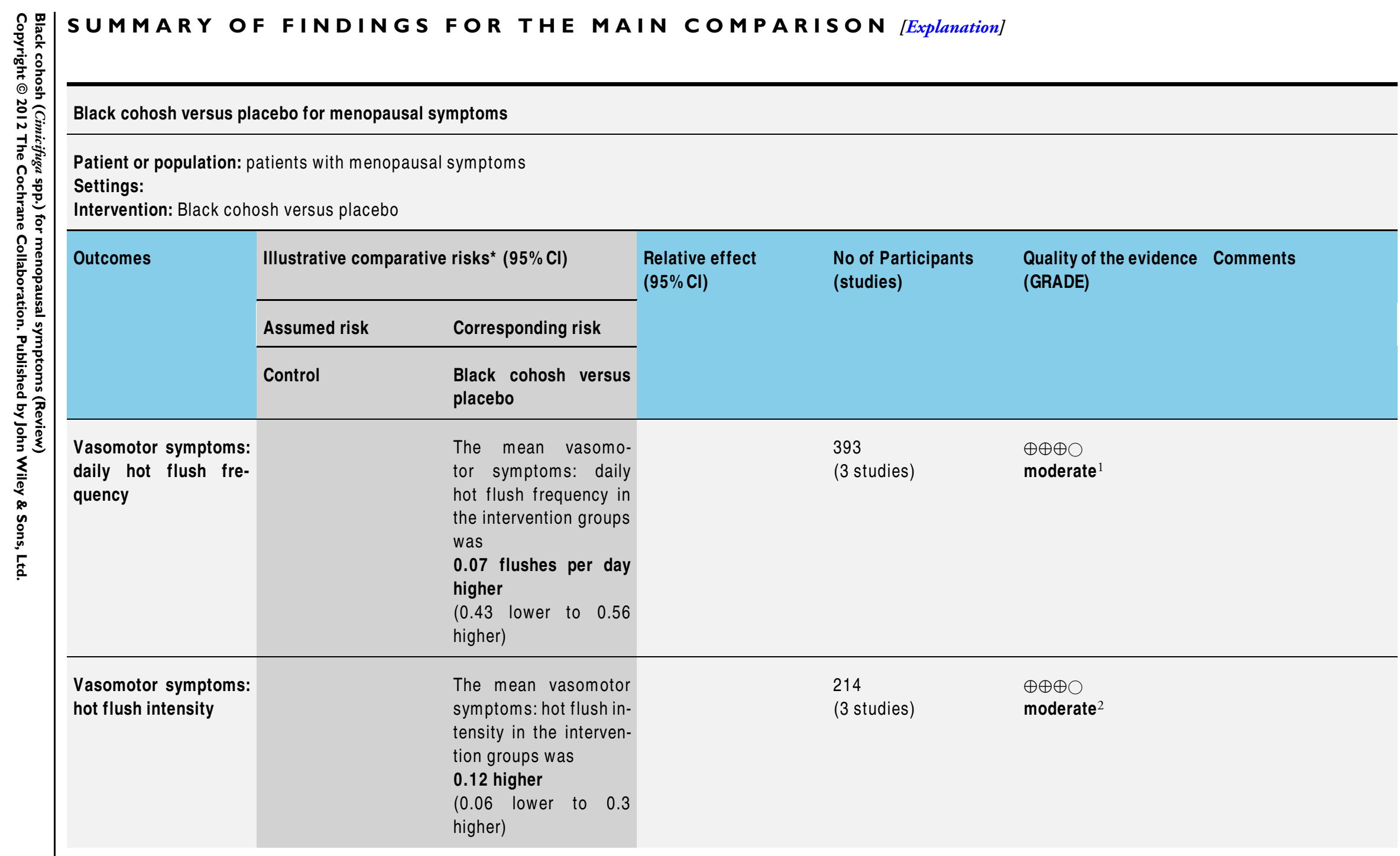




\begin{tabular}{|c|c|c|c|c|c|c|}
\hline $\begin{array}{l}\text { Vasomotor symptoms: } \\
\text { night sweats }\end{array}$ & & $\begin{array}{l}\text { The mean vasomo- } \\
\text { tor symptoms: night } \\
\text { sweats in the interven- } \\
\text { tion groups was } \\
0.27 \text { sweats per night } \\
\text { higher } \\
(0.16 \text { lower to } 0.7 \\
\text { higher) }\end{array}$ & & $\begin{array}{l}164 \\
\text { (1 study) }\end{array}$ & $\begin{array}{l}\oplus \oplus \oplus \bigcirc \\
\text { moderate }^{3}\end{array}$ & \\
\hline $\begin{array}{l}\text { Menopausal Symptom } \\
\text { Score }\end{array}$ & & $\begin{array}{l}\text { The mean menopausal } \\
\text { symptom score in } \\
\text { the intervention groups } \\
\text { was } \\
0.1 \text { standard devia- } \\
\text { tions lower } \\
\text { ( } 0.32 \text { lower to } 0.11 \\
\text { higher) }\end{array}$ & & $\begin{array}{l}357 \\
\text { (4 studies) }\end{array}$ & $\begin{array}{l}\oplus \oplus \oplus \bigcirc \\
\text { moderate }^{4}\end{array}$ & SMD $-0.1(-0.32$ to 0.11$)$ \\
\hline Adverse events & 427 per 1000 & $\begin{array}{l}444 \text { events per } 1000 \\
\text { women } \\
(350 \text { to } 564)\end{array}$ & $\begin{array}{l}\text { RR } 1.04 \\
\text { (0.82 to } 1.32)\end{array}$ & $\begin{array}{l}344 \\
\text { (2 studies) }\end{array}$ & $\begin{array}{l}\oplus \oplus \bigcirc \bigcirc \\
\text { low }^{4,5}\end{array}$ & \\
\hline
\end{tabular}

*The basis for the assumed risk (e.g. the median control group risk across studies) is provided in footnotes. The corresponding risk (and its $95 \%$ confidence interval) is based on the assumed risk in the comparison group and the relative effect of the intervention (and its $95 \% \mathrm{Cl}$ ).

Cl: Confidence interval; RR: Risk ratio;

GRADE Working Group grades of evidence

High quality: Further research is very unlikely to change our confidence in the estimate of effect.

Moderate quality: Further research is likely to have an important impact on our confidence in the estimate of effect and may change the estimate.

Low quality: Further research is very likely to have an important impact on our confidence in the estimate of effect and is likely to change the estimate.

Very low quality: We are very uncertain about the estimate.

${ }^{1}$ Two of the three trials did not provide sufficient details for randomisation and allocation concealment and two trials did not

provide details for reasons for losses to follow up in each group

${ }^{2}$ All three trials lacked some methodological detail

${ }^{3}$ Evidence is based on a single trial 


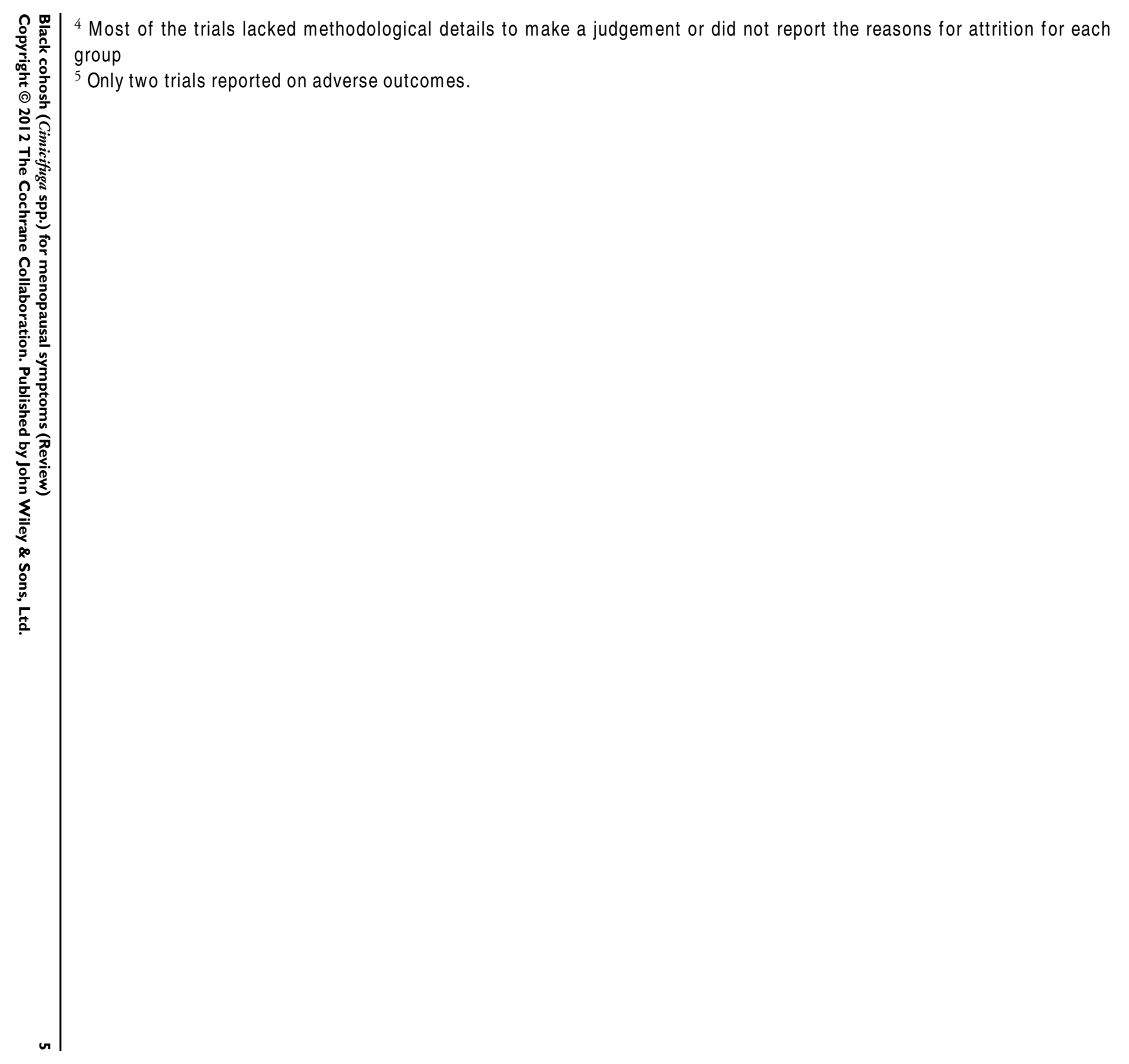




\section{B A C K G R O U N D}

\section{Description of the condition}

Menopause represents the cessation of menstruation and the end of the reproductive period; this typically occurs around 51 years of age (Porter 2011). Perimenopause is the period of transition to menopause, defined by irregular menstruation within the previous 12 months. Postmenopause is defined as the absence of menstruation for more than 12 months (Porter 2011). The events leading to menopause are attributed to a reduction in ovarian activity, which may stem from a physiological or iatrogenic (medically induced) cause. Physiological menopause occurs when the ageing ovaries become less responsive to follicle-stimulating hormone (FSH) and luteinising hormone (LH), resulting in fewer ovulations and decreasing amounts of circulating progesterone and oestrogen. Iatrogenic menopause results from medical intervention, such as oophorectomy (removal of the ovaries), chemotherapy and pelvic irradiation (Porter 2011). While the severity of symptoms of iatrogenic menopause is somewhat greater than physiological menopause, the types of symptoms reported are similar, with the most common manifestations including vasomotor symptoms (i.e. hot flushes and sweating), vulvovaginal atrophic symptoms (i.e. vaginal atrophy, vaginal dryness) and impaired sexual function (Corwin 2008). The average duration of these symptoms is 3.5 years (McKinlay 1992), although symptom duration can range anywhere from five months to 10 years, with the severity of these manifestations varying from mild to severe. Postmenopausal women are also at increased risk of osteoporosis (Corwin 2008), with the risk escalating with increasing age. This perimenopausal period may be also associated with a decline in quality of life (Blumel 2000). In fact, perimenopausal women report a significant decline $(\mathrm{P}=0.009)$ in perceived physical health and a marginally significant decline $(\mathrm{P}=0.05)$ in psychosomatic domains (i.e. nervous and emotional state, self confidence, work life, ability to make decisions and ability to concentrate) when compared to premenopausal women (Mishra 2006).

\section{Description of the intervention}

Black cohosh (Cimicifuga racemosa or Actaea racemosa), also known as bugbane, black snakeroot, rattle weed and wanzenkraut, is a tallstemmed plant with white (filiform) flowers extending from a wide base of serrated green foliage (Keville 1991). Belonging to the Ranunculaceae family, the plant is native to Canada and eastern US, and was traditionally used by Native Americans to treat malaria, impaired kidney function, sore throat, rheumatism, malaise, menstrual irregularities and childbirth (Blumenthal 2003). More recently, studies have focused their attention on examining the effectiveness of black cohosh in the treatment of menopausal symptoms and migraine, using extracts of the characteristic dark brownblack rhizome or underground stem of the plant.

\section{How the intervention might work}

The rhizome of black cohosh contains a number of biologically active constituents (including the triterpene glycosides actein and cimicifugoside, as well as fatty acids, resins, caffeic acids, isoferulic acids and isoflavones) (Mills 2000). Opinions vary regarding the physiological action of the plant. One explanation is that the isoflavone formononectin may directly stimulate oestrogen receptors (Borrelli 2003). However, the lack of a consistent effect on uterine weight in animals has shifted opinion, with many researchers now believing that black cohosh exerts its effect through a more central (brain-related) action. Many studies have demonstrated that black cohosh, particularly the triterpene glycosides, reduce circulating levels of LH (Borrelli 2003), which may in turn reduce some of the unpleasant symptoms of menopause. Experimentally, black cohosh has also demonstrated a capacity to stimulate dopaminergic-2 (D2) receptors (Borrelli 2003). This dopaminergic effect may not only oppose prolactin, which may improve libido, but may also improve bone mineral density by increasing osteoblast activity and hence, reduce bone metabolism and bone loss. These skeletal effects are not dissimilar to those induced by oestrogen (Borrelli 2003).

\section{How safe is the intervention}

A systematic review of the safety of black cohosh, used for a variety of menstrual and menopausal conditions, was published in 2008 (Borrelli 2008b) (after the study protocol was published). Twenty-eight studies were reviewed (13 clinical trials, three postmarketing surveillance trials, four case series and eight single case reports) involving 4232 women. The review found that adverse events associated with black cohosh when administered under trial conditions in doses ranging from $6.5 \mathrm{mg}$ to $160 \mathrm{mg}$ for a period lasting from one to 12 months were rare, mild and reversible. The most common side effects were gastrointestinal, musculoskeletal and connective tissue complaints (Borrelli 2008b). Isolated cases of hepatitis, hepatic failure, faciooral oedema and cutaneous vasculitis have also been reported in adverse event reporting programmes across the world, although there is insufficient evidence of a causal relationship between these side effects and black cohosh (Borrelli 2008b). A more recent review of the safety of herbal medicines corroborates this finding (Roberts 2010).

\section{Why it is important to do this review}

Interventions that decrease the severity and frequency of menopausal symptoms are likely to improve an individual's wellbeing and quality of life. The Australian Drug Evaluation Committee (ADEC) (ADEC 2004) advises that hormone therapy (HT) is an effective short-term treatment for controlling symptoms of menopause. To illustrate, women receiving HT for at least one year report a significant improvement in perceived physical health 
$(P=0.02)$ and a marginally significant improvement in psychosomatic domains $(\mathrm{P}=0.06)$ (Mishra 2006). These improvements in quality of life are not surprising, given that HT has been shown in a number of reviews to be effective at improving vasomotor (MacLennan 2004) and vulvovaginal atrophic symptoms (Peeyananjarassri 2005). However, HT is not without risk. Awareness of these risks was highlighted by the publication of the Women's Health Initiative study findings in 2002 (Rossouw 2002). As summarised in several Cochrane reviews, HT is associated with an increased incidence of venous thromboembolic events, pulmonary embolus, stroke (Gabriel-Sánchez 2005) and gallbladder disease (Farquhar 2005), while combined HT is associated with an increased risk of breast cancer (Farquhar 2005). Given the potential severity of these risks, it is important that treatments for menopausal symptoms, which are safer and less costly than HT, but comparatively effective, are identified so that the impact of climacteric symptoms on perimenopausal women can be attenuated and quality of life improved.

\section{O B J E C T I V E S}

To evaluate the clinical effectiveness and safety of black cohosh for treating menopausal symptoms in perimenopausal and postmenopausal women.

The specific review questions addressed were:

- how effective is black cohosh at reducing the frequency or intensity of menopausal symptoms in perimenopausal and postmenopausal women?

- how safe is black cohosh in perimenopausal and postmenopausal women when taken to alleviate the symptoms of menopause?

\section{METHODS}

\section{Criteria for considering studies for this review}

\section{Types of studies}

The review considered any published or unpublished randomised controlled trials (RCTs) that had evaluated the effectiveness of black cohosh in menopause, without restriction on language or trial duration. Other research designs, such as observational studies and case studies, were excluded.

\section{Types of participants}

Participants were limited to women 18 years of age or older with surgical or spontaneous menopause, experiencing climacteric symptoms in the perimenopausal or postmenopausal period and recruited from any setting. Perimenopausal women were defined as women with spontaneous menopause who have experienced irregular menstruation within the previous 12 months. Postmenopausal women were defined as women with surgical or spontaneous menopause and amenorrhoea for more than 12 months (Porter 2011). All women, regardless of any prior or existing morbidity, were included.

\section{Types of interventions}

The main intervention included any orally administered monopreparation of black cohosh of any dose, form and duration. Combination preparations of black cohosh were excluded. The comparator group could include the use of placebo, active medication such as HT, or other herbal and nutritional preparations.

\section{Types of outcome measures}

\section{Primary outcomes}

1. Change in frequency or intensity of vasomotor symptoms (i.e. hot flushes, night sweats).

i) Hot flushes:

a) frequency of hot flushes;

b) intensity of hot flushes.

ii) Night sweats:

a) frequency of night sweats;

b) intensity of night sweats.

2. Change in frequency or intensity of vulvovaginal atrophic symptoms (i.e. vaginal dryness).

3. Change in menopausal symptom scores that derive numerical results from a combination of menopausal symptoms (i.e. Kupperman Index (KI), Greene Climacteric Scale (GCS), Menopause Rating Scale (MRS)).

4. Incidence and type of adverse effects.

\section{Secondary outcomes}

1. Health-related quality of life (HRQoL).

2. Sexuality (i.e. measures of sexual desire, libido).

3. Bone health (i.e. bone density, fracture rate).

4. Cost effectiveness.

\section{Search methods for identification of studies}

See: CochraneMenstrualDisordersandSubfertilityGroup methods used in reviews. 


\section{Electronic searches}

The authors searched the following electronic sources from inception to March 2012 for the identification of trials:

- AARP Ageline;

- Allied \& Complementary Medicine (AMED);

- Australasian Medical Index (AMI);

- BioMed Central gateway;

- CAM on PubMed;

- CINAHL;

- Cochrane Central Register of Controlled Trials

(CENTRAL) (The Cochrane library);

- Cochrane Menstrual Disorders and Subfertility group Trials Register;

- EMBASE;

- Health Source Nursing/Academic edition;

- International Pharmaceutical Abstracts;

- MEDLINE;

- Natural medicines comprehensive database;

- PsycINFO;

- Turning Research Into Practice (TRIP) database.

The authors also searched databases of ongoing trials ( www.controlled-trials.com/ and www.clinicaltrialsregister.eu/). For a description of the search strategies, see Appendix 1, Appendix
2, Appendix 3, Appendix 4, Appendix 5, Appendix 6, Appendix 7, Appendix 8, Appendix 9, Appendix 10, Appendix 11, Appendix 12, Appendix 13, Appendix 14 and Appendix 15.

\section{Searching other resources}

Additional studies were sought by searching the reference lists of included trials and (systematic) reviews, meta-analyses and Health Technology Assessment reports.

Content experts and manufacturers of black cohosh extracts were contacted in order to obtain additional references, as well as details of unpublished trials and ongoing trials. The grey literature was also searched for unpublished studies using 'Dissertations Abstracts International' and 'Proceedings First'.

\section{Data collection and analysis}

\section{Selection of studies}

Two independent review authors critically appraised each study (ML, VM), one of whom was a content expert (ML). Disagreement was resolved by discussion. A PRISMA (Preferred Reporting Items for Systematic Reviews and Meta-Analyses) flow chart was compiled to summarise the study selection process (Figure 1). 
Figure I. Study flow diagram.

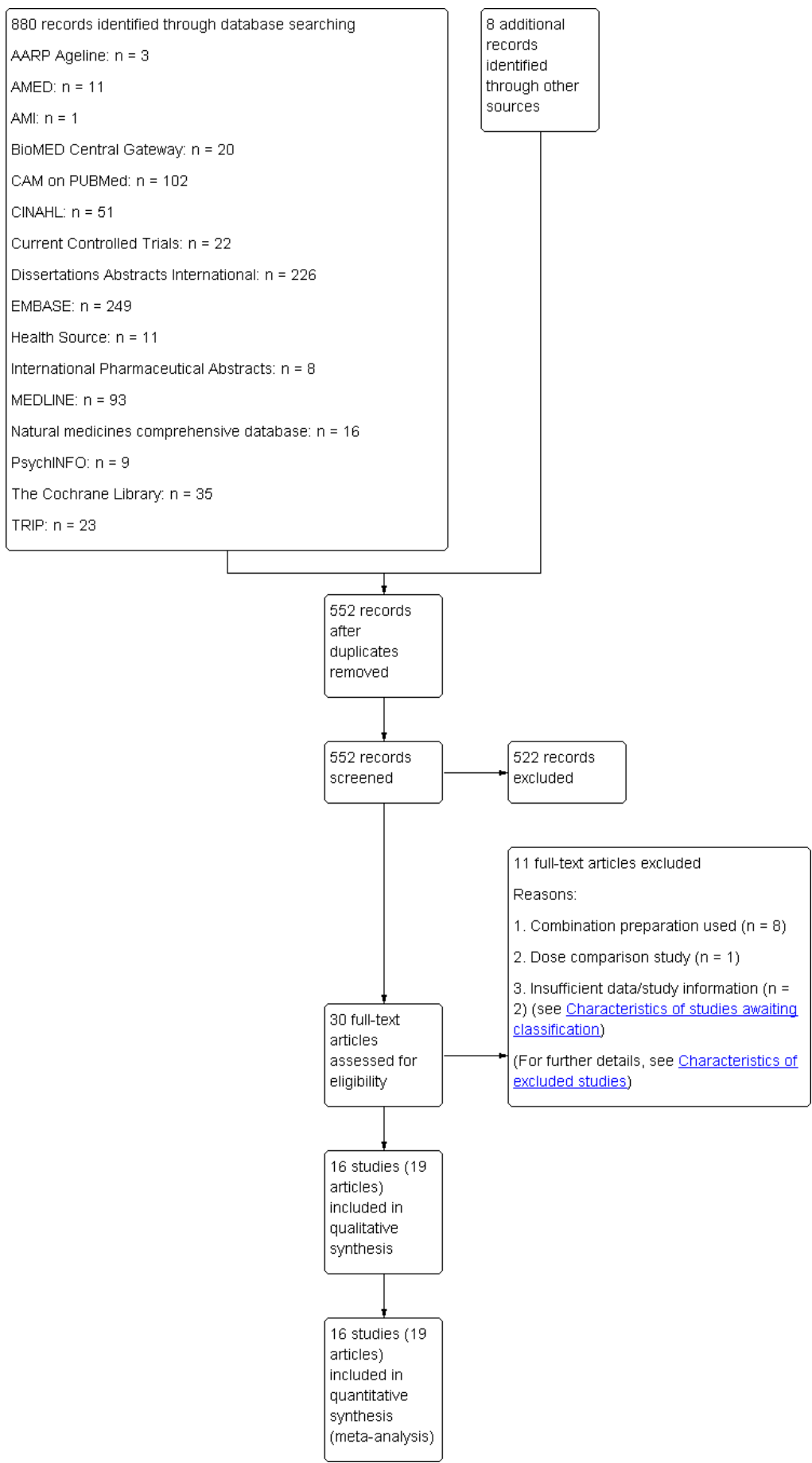

Black cohosh (Cimicifuga spp.) for menopausal symptoms (Review) 


\section{Data extraction and management}

Two review authors (ML, VM) independently extracted data and reported it in the Characteristics of included studies and Characteristics of ongoing studies tables. Disagreement was resolved by discussion.

\section{Assessment of risk of bias in included studies}

The review authors used 'The Cochrane Collaboration tool for assessing risk of bias' to critically appraise each study (Higgins 2011) and report them in the 'Risk of bias' table. The Cochrane tool (Table 1) consists of six domains, including selection bias (sequence generation and allocation concealment), performance bias (blinding of participants and personnel), detection bias (blinding of outcome assessors), attrition bias (incomplete outcome data), within-trial selective reporting and other sources of bias. Judgements are 'low risk of bias', 'high risk of bias' and 'unclear risk of bias'.

\section{Measures of treatment effect}

To analyse the size of the effects of the interventions, mean differences (MD) and 95\% confidence intervals (CI) were calculated for continuous data; except where different scales were used (i.e. menopausal symptom scores, frequency of hot flushes per day or week), in which case, standardised mean differences (SMD) and 95\% CIs were calculated. For dichotomous data, effect sizes were expressed as risk ratios (RR) with $95 \%$ CIs. To control for potential carry-over effects in cross-over studies (Pockaj 2006), only the first arm of the study was considered in the analysis.

\section{Unit of analysis issues}

The unit of analysis was the woman randomised to treatment.

\section{Dealing with missing data}

Data were analysed on an intention-to-treat (ITT) basis as far as possible, and attempts were made to obtain missing data or other clarification from the original study authors. No imputations were made where data were missing.

\section{Assessment of heterogeneity}

The review authors considered whether the clinical and methodological characteristics of the included studies were sufficiently similar for meta-analysis to provide a clinically meaningful summary. Heterogeneity was identified by visual inspection of the forest plots, by using a standard $\mathrm{Chi}^{2}$ test and an $\alpha$ significance level of 0.1 in view of the low power of such tests. Heterogeneity was specifically examined with $I^{2}$ (Higgins 2002), where $I^{2}$ values of $50 \%$ or more indicated a substantial level of heterogeneity (Higgins 2011). The review authors explored the causes of heterogeneity by conducting subgroup and sensitivity analyses, using a random-effects model, if heterogeneity was found.

\section{Assessment of reporting biases}

A comprehensive search for trials was undertaken without restriction on publication status. Several of the studies included in this review have a number of associated publications. For this review, we planned a priori to select only studies that reported the primary and secondary outcomes of interest.

\section{Data synthesis}

If two or more eligible studies were comparable in terms of extract dose and formulation, participant demographics and disease activity, data (final value scores only) were pooled in a meta-analysis with Review Manager (RevMan) 5 software (RevMan 2011), using a fixed-effect model. Data were pooled separately depending on whether a placebo or active intervention was used.

\section{Subgroup analysis and investigation of heterogeneity}

In the presence of significant heterogeneity, the review authors performed pre-specified subgroup analyses to examine the causes of the heterogeneity (if there were sufficient studies). In any other case, subgroup analyses were clearly marked as a hypothesis-generating exercise. The following subgroup analyses were performed:

1. effect of black cohosh dosage (i.e. low-dose $(<40 \mathrm{mg})$, moderate-dose ( 40 to $80 \mathrm{mg}$ ) and high-dose $(>80 \mathrm{mg})$ ) on primary outcome measures;

2. effect of treatment duration (i.e. short-term ( $\leq 12$ weeks), moderate-term (13 to 36 weeks) and long-term ( 37 to 52 weeks)) on primary outcome measures.

\section{Sensitivity analysis}

Sensitivity analyses were planned a priori to explore the influence of the following factors on effect size (where there were sufficient studies to make this possible):

1. repeating the analysis excluding low-quality studies, in particular, studies with inadequate random sequence generation, treatment concealment and double blinding (i.e. studies were defined as low quality if any of the first three items of the 'Risk of bias' table were rated as unclear or high risk); 
2. repeating the analysis excluding any very long (i.e. $\geq 52$ weeks) or large studies (i.e. $\geq 200$ women) to establish how much they dominate the results.

During the review it became apparent that subgroup and sensitivity analyses were not meaningful when there were few studies available. Subgroup and sensitivity analyses were therefore only performed when five or more studies were available for the subgroup or factor.

\section{Summary of Findings Table}

The overall quality of the body of evidence comparing black cohosh versus placebo was summarised using GRADE criteria, which evaluate study limitations (i.e. risk of bias), consistency of effect, imprecision, indirectness and publication bias.

\section{R E S U L T S}

\section{Description of studies}

For a detailed description of studies, see Characteristics of included studies, Characteristics of excluded studies and Characteristics of ongoing studies.

\section{Results of the search}

The initial search identified 888 records. From these, 30 records were identified for further examination. The other records were excluded on the basis of their abstracts because they did not fulfil the inclusion criteria $(n=522)$ or duplicated records already located ( $\mathrm{n}=336$ ) (see Figure 1 for the PRISMA flow chart). After screening the full text of selected papers, 11 articles were excluded as they used a combination preparation, were a dose comparison study, or provided insufficient data or study information. Sixteen studies (19 articles) met the inclusion criteria, of which 14 were published in English, and two in German (Lehmann-Willenbrock 1988; Stoll 1987).

\section{Included studies}

Additional data were sought from the authors of 11 studies (Amsterdam 2009; Bai 2007; Frei-Kleiner 2005; Geller 2009; Jacobson 2001; Kronenberg 2009; Nappi 2005; Newton 2006; Osmers 2005; Pockaj 2006; Wuttke 2003). Nine authors responded to these requests (Amsterdam 2009; Bai 2007; FreiKleiner 2005; Geller 2009; Jacobson 2001; Kronenberg 2009; Nappi 2005; Newton 2006; Pockaj 2006). A detailed description of the characteristics of included studies is presented elsewhere (see Characteristics of included studies). The following is a brief overview.

\section{Study design}

All studies were RCTs. Thirteen of the 16 studies were doubleblind (Amsterdam 2009; Bai 2007; Bebenek 2010; Carlisle 2008; Frei-Kleiner 2005; Geller 2009; Jacobson 2001; Kronenberg 2009; Newton 2006; Osmers 2005; Pockaj 2006; Stoll 1987; Wuttke 2003). Fifteen studies employed a parallel-group design, and one study employed a cross-over design (Pockaj 2006). A runin period, ranging from one to two weeks (mean 1.8 weeks), was implemented in four studies (Frei-Kleiner 2005; Newton 2006; Pockaj 2006; Wuttke 2003) and a follow-up period of 24 weeks was implemented in one study (Lehmann-Willenbrock 1988). Study duration ranged between eight and 54 weeks, with a mean duration of 22.8 weeks.

\section{Participants}

A total of 2027 female participants were randomised in the 16 trials. The sample size ranged from 23 to 351, with a median size of 93 women. The mean age of women in the trials ranged from 50.5 to 56.4 years. All studies included perimenopausal and postmenopausal women, except for four studies (Bebenek 2010; Carlisle 2008; Kronenberg 2009; Oktem 2007), which recruited postmenopausal women only. The mean body mass index (BMI) of women exceeded $25.0 \mathrm{~kg} / \mathrm{m}^{2}$ in six of eight studies that recorded BMI (Carlisle 2008; Geller 2009; Kronenberg 2009; Newton 2006; Oktem 2007; Osmers 2005). Additional baseline data are presented in Table 2, Table 3 and Table 4. Criteria for entry into the individual studies are outlined in the Characteristics of included studies.

\section{Interventions}

All studies used oral monopreparations of Cimicifuga racemosa as the active intervention; six studies used an ethanolic extract (Amsterdam 2009; Frei-Kleiner 2005; Geller 2009; Kronenberg 2009; Newton 2006; Wuttke 2003), six used an isopropanolic extract (Bai 2007; Jacobson 2001; Lehmann-Willenbrock 1988; Nappi 2005; Osmers 2005; Stoll 1987) and in four studies (Bebenek 2010; Carlisle 2008; Oktem 2007; Pockaj 2006), the solvent was not defined. Seven studies specifically identified the root/rhizome of C. racemosa as the part used (Bai 2007; Geller 2009; Kronenberg 2009; Newton 2006; Osmers 2005; Pockaj 2006; Wuttke 2003). Six studies used the proprietary formulation Remifemin ${ }^{\circledR}$ (Bai 2007; Jacobson 2001; Lehmann-Willenbrock 1988; Nappi 2005; Osmers 2005; Stoll 1987), and two studies used CimiPure ${ }^{\circledR}$ (Kronenberg 2009; Newton 2006). The daily dose of $C$. racemosa extract varied between 8 and $160 \mathrm{mg}$, with a median daily dose of $40 \mathrm{mg}$. In six studies, C. racemosa extracts were standardised to $2.5 \%$ to $5.68 \%$ triterpene glycosides (mean 3.96\%) (Amsterdam 2009; Carlisle 2008; Geller 2009; Kronenberg 2009; Newton 2006; Pockaj 2006). In terms of control interventions, 11 studies used placebo controls (Amsterdam 
2009; Bebenek 2010; Carlisle 2008; Frei-Kleiner 2005; Geller 2009; Jacobson 2001; Kronenberg 2009; Newton 2006; Osmers 2005; Pockaj 2006; Stoll 1987), and eight used active controls (Bai 2007; Geller 2009; Lehmann-Willenbrock 1988; Nappi 2005; Newton 2006; Oktem 2007; Stoll 1987; Wuttke 2003). The active controls included oestrogen therapy (Lehmann-Willenbrock 1988; Stoll 1987; Wuttke 2003), combined oestrogen/progesterone therapy (Geller 2009; Lehmann-Willenbrock 1988; Nappi 2005; Newton 2006), tibolone (Bai 2007), Trifolium pratense (Geller 2009), fluoxetine (Oktem 2007), multi-botanical (Newton 2006) and soy dietary counselling (Newton 2006). Treatment duration across all studies ranged from four to 52 weeks, with a mean duration of 23.4 weeks.

\section{Outcomes}

The number or intensity, or both, of vasomotor symptoms (e.g. hot flushes, night sweats) were reported in 13 studies (Amsterdam 2009; Bai 2007; Frei-Kleiner 2005; Geller 2009; Jacobson 2001; Kronenberg 2009; Nappi 2005; Newton 2006; Oktem 2007; Osmers 2005; Pockaj 2006; Stoll 1987; Wuttke 2003). Three studies presented data on sexual dysfunction (Frei-Kleiner 2005; Geller 2009; Stoll 1987) and four measured vulvovaginal symptoms (Geller 2009; Newton 2006; Stoll 1987; Wuttke 2003). Bone health (e.g. bone metabolism, bone density) was measured in five trials (Bebenek 2010; Carlisle 2008; Geller 2009; Kronenberg 2009; Wuttke 2003) and quality of life assessed in four (Geller 2009; Kronenberg 2009; Oktem 2007; Pockaj 2006). All but one study (Carlisle 2008) reported menopausal symptom scores using standardised scales or indices (i.e. scores deriving numerical results from a combination of menopausal symptoms). Adverse events were explicitly reported in 10 studies (Amsterdam 2009; Bai 2007; Frei-Kleiner 2005; Jacobson 2001; Kronenberg 2009; Nappi 2005; Newton 2006; Oktem 2007; Osmers 2005; Wuttke
2003).

\section{Settings}

Seven of the 16 studies were implemented across multiple centres (Bai 2007; Frei-Kleiner 2005; Geller 2009; Newton 2006; Osmers 2005; Pockaj 2006; Wuttke 2003) and four within single centres (Kronenberg 2009; Lehmann-Willenbrock 1988; Nappi 2005; Oktem 2007). Five studies did not define the number of centres involved (Amsterdam 2009; Bebenek 2010; Carlisle 2008; Jacobson 2001; Stoll 1987). The number of centres in multicentre trials ranged from two to 24, with an average of 12 centres. Seven studies were conducted in the US (Amsterdam 2009; Carlisle 2008; Geller 2009; Jacobson 2001; Kronenberg 2009; Newton 2006; Pockaj 2006), four in Germany (Bebenek 2010; Lehmann-Willenbrock 1988; Osmers 2005; Stoll 1987), and one each in China (Bai 2007), Switzerland (Frei-Kleiner 2005), Italy (Nappi 2005), Turkey (Oktem 2007) and Czech Republic (Wuttke 2003).

For further details, see Characteristics of included studies.

\section{Excluded studies}

Nine studies had to be excluded after careful evaluation of the full publication. Main reasons for exclusion were inappropriate comparator group (Liske 2002), and use of combination preparation (Blohmer 2007; Chung 2007; Myoung 2008; Park 2006; Rotem 2007; Sammartino 2006; Uebelhack 2006; Verhoeven 2005). For further details, see Characteristics of excluded studies.

\section{Risk of bias in included studies}

The methodological quality of the included studies is summarised in Figure 2 and Figure 3. 
Figure 2. Risk of bias summary: review authors' judgements about each risk of bias item for each included study.

\begin{tabular}{|c|c|c|c|c|c|c|}
\hline & 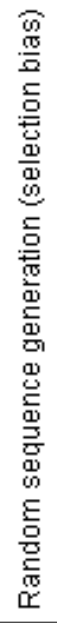 & 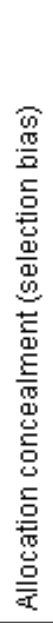 & 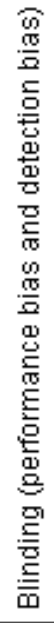 & 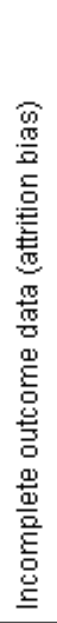 & 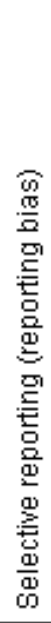 & 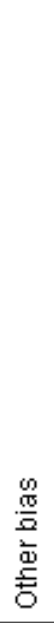 \\
\hline Amsterdam 2009 & + & $?$ & $?$ & + & ? & $?$ \\
\hline Bai 2007 & $?$ & $?$ & + & & $?$ & + \\
\hline Bebenek 2010 & + & $?$ & + & & $?$ & + \\
\hline Carlisle 2008 & + & $?$ & + & & $?$ & $?$ \\
\hline Frei-Kleiner 2005 & $?$ & $?$ & + & & & $?$ \\
\hline Geller 2009 & + & $?$ & + & & $?$ & $?$ \\
\hline Jacobson 2001 & + & ? & $?$ & 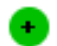 & $?$ & $?$ \\
\hline Kronenberg 2009 & $?$ & $?$ & $?$ & 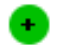 & & + \\
\hline Lehmann-Willenbrock 1988 & $?$ & $?$ & $?$ & & $?$ & $?$ \\
\hline Nappi 2005 & + & ? & & & ? & + \\
\hline Newton 2006 & + & + & + & + & ? & ? \\
\hline oktem 2007 & $?$ & ? & $?$ & & ? & + \\
\hline Osmers 2005 & $?$ & $?$ & $?$ & + & $?$ & + \\
\hline Pockaj 2006 & $?$ & $?$ & + & & & + \\
\hline Stoll 1987 & $?$ & $?$ & + & & $?$ & $?$ \\
\hline Wuttke 2003 & $?$ & $?$ & + & & & $?$ \\
\hline
\end{tabular}


Figure 3. Risk of bias graph: review authors' judgements about each 'Risk of bias' item presented as percentages across all included studies.

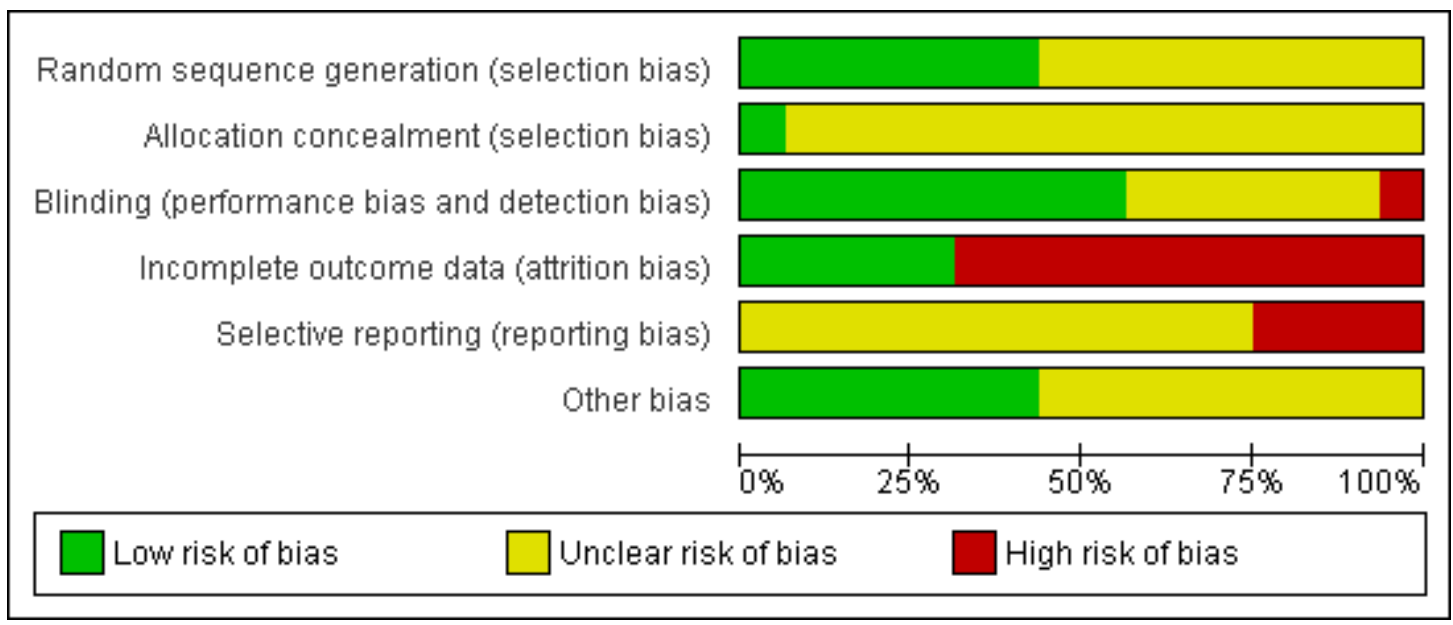

\section{Allocation}

All trials were reported as randomised. Only seven studies explicitly described the method of randomisation and were assessed to be at low risk of selection bias; four of these studies used block randomisation (Amsterdam 2009; Bebenek 2010; Geller 2009; Newton 2006) and three used computer-generated lists (Carlisle 2008; Jacobson 2001; Nappi 2005). Allocation concealment was reported in only one study (Newton 2006); this was the only study rated as having low risk of bias for this domain; all other studies were rated as unclear risk.

\section{Blinding}

Thirteen studies were described as double-blind, but only nine trials (Bai 2007; Bebenek 2010; Carlisle 2008; Frei-Kleiner 2005; Geller 2009; Newton 2006; Pockaj 2006; Stoll 1987; Wuttke 2003) provided an adequate description of blinding, including assurance that interventions and controls were identical. These nine trials were rated as having low risk of performance and detection bias. Five trials failed to identify who was blinded or whether interventions were identical, or both (Amsterdam 2009; Jacobson 2001; Kronenberg 2009; Nappi 2005; Osmers 2005), and two studies did not mention blinding (Lehmann-Willenbrock 1988; Oktem 2007). Of these seven trials, one was assessed to be at high risk of bias for this domain (Nappi 2005) and the remaining six at unclear risk.

\section{Incomplete outcome data}

Analysis was reported to be by ITT in five trials (Amsterdam 2009; Jacobson 2001; Kronenberg 2009; Newton 2006; Osmers 2005). These trials were assessed to be at low risk of attrition bias. All remaining studies were determined to be at high risk of bias for this domain. Of these, one trial (Geller 2009) did not use true ITT analysis, and five studies (Bai 2007; Bebenek 2010; Carlisle 2008; Frei-Kleiner 2005; Wuttke 2003) appeared to be analysed by perprotocol (PP) analysis. In five trials (Lehmann-Willenbrock 1988; Nappi 2005; Oktem 2007; Pockaj 2006; Stoll 1987), neither ITT nor PP analysis was reported.

Seven studies (Frei-Kleiner 2005; Kronenberg 2009; LehmannWillenbrock 1988; Newton 2006; Oktem 2007; Pockaj 2006; Wuttke 2003) failed to provide detailed descriptions of subject withdrawals or reasons for withdrawal, or both. Differences between groups in the number or reasons for withdrawal were evident in five trials (Bai 2007; Bebenek 2010; Carlisle 2008; Geller 2009; Stoll 1987).

\section{Selective reporting}

Twelve trials (Amsterdam 2009; Bai 2007; Bebenek 2010; Carlisle 2008; Geller 2009; Jacobson 2001; Lehmann-Willenbrock 1988; Nappi 2005; Newton 2006; Oktem 2007; Osmers 2005; Stoll 1987) reported all primary and secondary outcomes; however, no studies published or lodged a trial protocol. These trials were

Black cohosh (Cimicifuga spp.) for menopausal symptoms (Review) 
assessed to be at unclear risk of reporting bias. Four studies (FreiKleiner 2005; Kronenberg 2009; Pockaj 2006; Wuttke 2003) did not report all secondary outcomes, and were determined to be at high risk of bias for this domain.

\section{Other potential sources of bias}

There were other potential sources of bias among included trials. Baseline differences between groups were observed in eight studies (Amsterdam 2009; Carlisle 2008; Frei-Kleiner 2005; Geller 2009; Jacobson 2001; Newton 2006; Stoll 1987; Wuttke 2003). One study did not report participant characteristics at baseline (Lehmann-Willenbrock 1988). Seven trials (Bai 2007; Bebenek 2010; Kronenberg 2009; Nappi 2005; Oktem 2007; Osmers 2005; Pockaj 2006) were considered low risk in terms of other potential sources of bias; all remaining studies were determined to be at unclear risk of bias for this domain.

\section{Effects of interventions}

See: Summary of findings for the main comparison Black cohosh versus placebo for menopausal symptoms Results are reported below by comparison, as follows:

- black cohosh versus placebo;

- black cohosh versus HT;
- black cohosh versus red clover;

- black cohosh versus fluoxetine.

\section{Black cohosh versus placebo}

\section{Primary outcomes}

1. Change in frequency or intensity of vasomotor symptoms

\subsection{Hot flushes}

\subsubsection{Frequency of hot flushes}

Five trials were suitable for analysis; they reported hot flush frequency per day (Frei-Kleiner 2005; Newton 2006; Pockaj 2006) or per week (Geller 2009; Kronenberg 2009).

There was no statistically significant difference in the mean number of hot flushes per day between the black cohosh and placebo groups (MD 0.07; 95\% CI -0.43 to 0.56 ; $\mathrm{P}=0.79$; 393 women; three trials; Analysis 1.1; Figure 4), with moderate heterogeneity $\left(\mathrm{I}^{2}=47 \%\right)$. This evidence was rated as moderate quality using GRADE criteria. See Summary of findings for the main comparison.

Figure 4. Forest plot of comparison: I Black cohosh versus placebo, outcome: I.I Vasomotor symptoms: daily hot flush frequency.

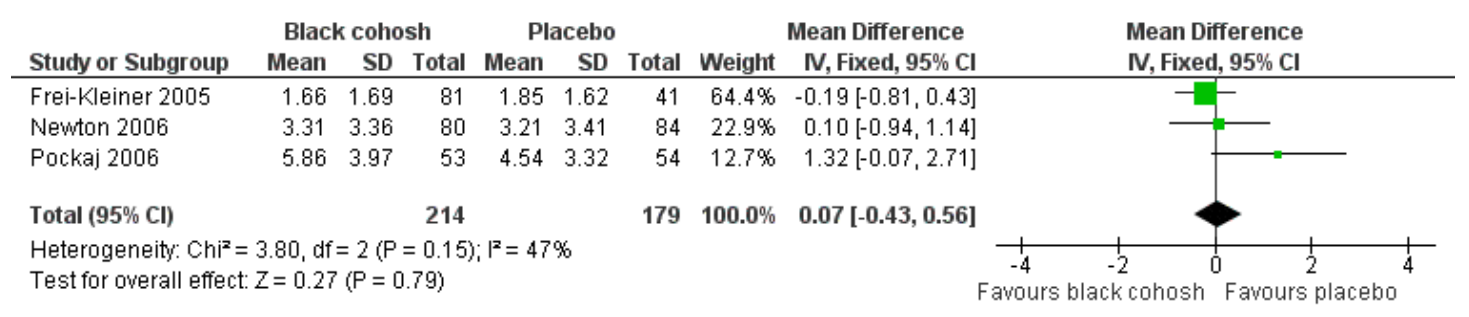

The two trials reporting hot flushes per week were unsuitable for pooling owing to high heterogeneity between them $\left(\mathrm{I}^{2}=91 \%\right)$, for which there was no clear explanation. One of these trials ( Kronenberg 2009) found no significant difference between the groups $(-2.90 ; 95 \%$ CI -12.89 to $7.09 ; 65$ women), while the second (Geller 2009) reported significantly fewer hot flushes in the placebo group (17.89; 95\% CI 9.57 to 26.21) (Analysis 1.2). 1.1.2 Intensity of hot flushes

Three trials (Geller 2009; Kronenberg 2009; Pockaj 2006) were suitable for analysis. The difference in the mean intensity of hot flushes between treatment groups was not statistically significant (MD 0.12; 95\% CI -0.06 to $0.30 ; \mathrm{P}=0.19 ; 214$ women; three trials; Analysis 1.3). There was moderate heterogeneity $\left(\mathrm{I}^{2}=42 \%\right)$ between studies. This evidence was rated as moderate quality using GRADE criteria. See Summary of findings for the main comparison.

\subsection{Night sweats}

1.2.1 Frequency of night sweats 
One trial (Newton 2006) assessed the frequency of night sweats. The difference in the mean number of night sweats per day between the black cohosh and placebo groups was not statistically significant (MD 0.27; 95\% CI -0.16 to $0.70 ; \mathrm{P}=0.21 ; 164$ women one trial; Analysis 1.4). This evidence was rated as moderate quality: see Summary of findings for the main comparison.

1.2.2 Intensity of night sweats

No trials compared black cohosh versus placebo for intensity of night sweats.

\section{Change in frequency or intensity of vulvovaginal symptoms}

Vulvovaginal symptoms were assessed in four trials of black cohosh versus placebo (Geller 2009; Newton 2006; Stoll 1987; Wuttke 2003). Two trials assessed vaginal dryness (Geller 2009; Newton 2006), two measured vaginal bleeding (Newton 2006; Wuttke 2003) and one reported vaginal pruritus (Stoll 1987). However, data were insufficient for analysis.

\section{Menopausal symptom score}

Five studies were suitable for pooling. Two used the KI (FreiKleiner 2005; Geller 2009), two used the GCS (Amsterdam 2009; Geller 2009), one used the MRS (Frei-Kleiner 2005) and one used the Wiklund Menopause Symptom Score (Newton 2006).

Pooling data for all studies showed no statistically significant difference in menopausal symptom scores between black cohosh and placebo (SMD - $0.10 ; 95 \%$ CI -0.32 to $0.11 ; \mathrm{P}=0.34 ; 357$ women; four trials; Analysis 1.5; Figure 5), with low heterogeneity $\left(\mathrm{I}^{2}=\right.$ 21\%). Note that two trials (Frei-Kleiner 2005; Geller 2009) each reported results for two scales. For this analysis, only results for one scale were used; the overall effect changed little regardless of the scale selected for inclusion (four possible combinations). This evidence was rated as moderate quality: see Summary of findings for the main comparison.

Figure 5. Forest plot of comparison: I Black cohosh versus placebo, outcome: I.5 Menopausal Symptom Score.

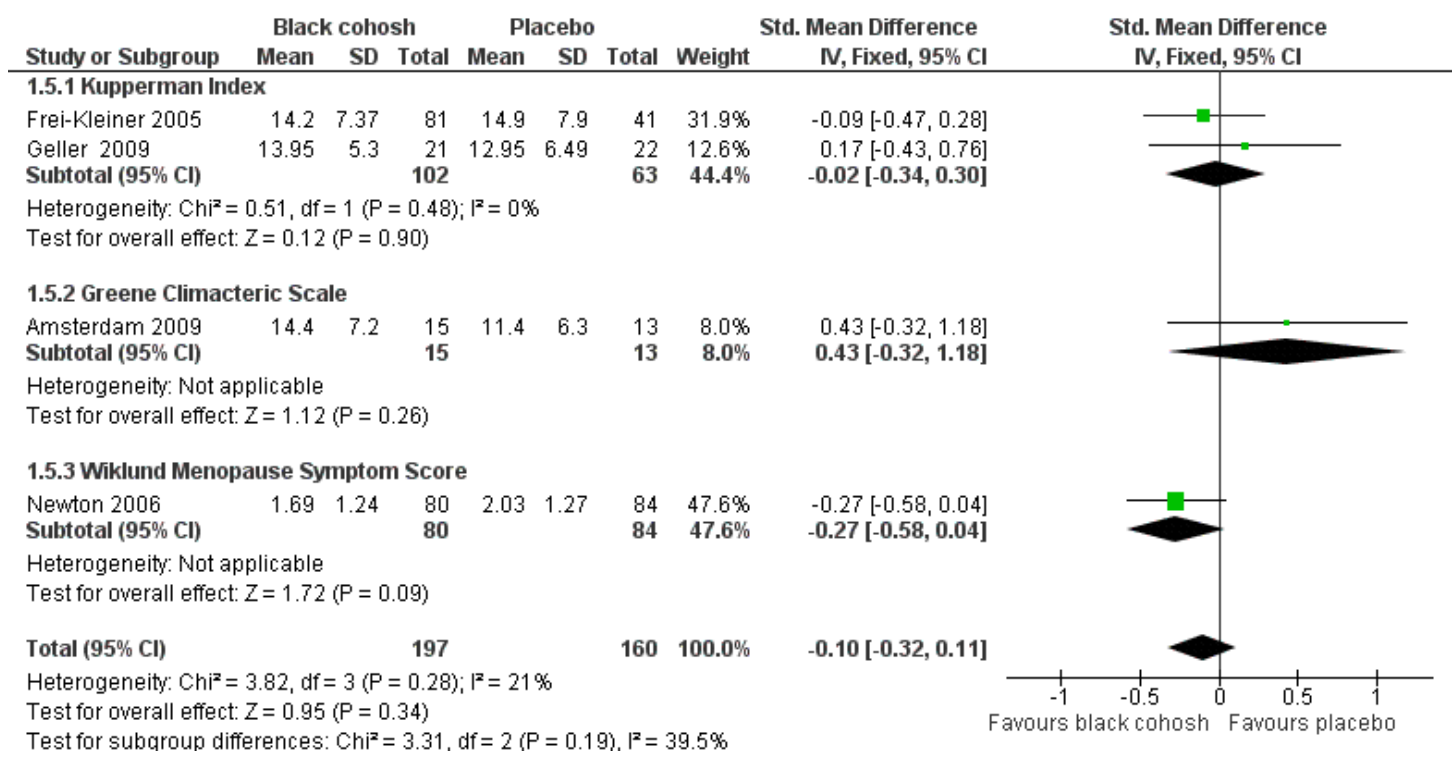

Other studies reported no data suitable for meta-analysis (Bebenek 2010; Jacobson 2001; Kronenberg 2009; Osmers 2005; Pockaj 2006; Stoll 1987; Wuttke 2003).

\section{Adverse effects}

Seven trials reported adverse effects (Amsterdam 2009; FreiKleiner 2005; Jacobson 2001; Kronenberg 2009; Newton 2006;
Osmers 2005; Wuttke 2003). A total of 194 adverse events were reported in 430 women ( 0.45 events/person) assigned to black cohosh and 195 events in 392 women (0.50 events/person) assigned to placebo.

The number of women experiencing adverse events (as opposed to the total number of events recorded) was reported in two trials

Black cohosh (Cimicifuga spp.) for menopausal symptoms (Review) 
(Osmers 2005; Wuttke 2003); a total of 53 women reported adverse events among 173 women randomised to black cohosh, compared to 50 in 171 women randomised to placebo. The difference between groups was not statistically significant (RR 1.04; 95\% CI 0.82 to $1.32 ; \mathrm{P}=0.74 ; 344$ women; two trials; Analysis 1.6 ). This evidence was rated as low quality: see Summary of findings for the main comparison.

\section{Secondary outcomes}

\section{Health-related quality of life}

HRQoL was assessed in three trials (Geller 2009; Kronenberg 2009; Pockaj 2006), but none reported extractable data.

\section{Sexuality}

Sexual dysfunction was measured in four trials (Frei-Kleiner 2005; Geller 2009; Newton 2006; Stoll 1987), though data were reported in only one (Stoll 1987). However, these data were incomplete and the outcome was not defined. The data were also not suitable for narrative synthesis as differences in the severity of sexual complaints between the black cohosh, HT and placebo groups were not tested.

\section{Bone health}

Five studies assessed bone health. However, data were insufficient for analysis. Of the three studies measuring bone mineral density (Bebenek 2010; Geller 2009; Kronenberg 2009), one reported no data (Kronenberg 2009), and two $(\mathrm{n}=129)$ found no statistically significant difference between the black cohosh and control groups in the bone density of the lumbar spine and femoral head on completion of the trial (Bebenek 2010; Geller 2009). The one trial $(n=62)$ measuring alkaline phosphatase (ALP) and telopeptides of type 1 collagen (Wuttke 2003) reported a statistically significant increase in serum ALP after black cohosh treatment when compared with placebo, but no difference between black cohosh and controls in the levels of telopeptides of type 1 collagen. Another trial measuring serum osteocalcin and C-terminal telopeptide (Carlisle 2008) reported no statistically significant difference between black cohosh and placebo in either outcome at 12 weeks.

\section{Cost-effectiveness}

No trial examined cost-effectiveness as an endpoint.

\section{Black cohosh versus hormone therapy}

Primary outcomes

\section{Change in frequency or intensity of vasomotor symptoms}

\subsection{Hot flushes}

\subsubsection{Frequency of hot flushes}

Three trials were suitable for analysis; they reported hot flush frequency per day (Nappi 2005; Newton 2006) or per week (Geller 2009). These trials were not pooled owing to high heterogeneity $\left(\mathrm{I}^{2}=83 \%\right)$ between the two trials measuring hot flushes per day, for which there was no clear explanation.

All three trials reported significantly fewer hot flushes per day in the HT group than in the black cohosh group (Nappi 2005: MD 0.95 flushes per day; $95 \%$ CI 0.29 to 1.61 flushes per day; 42 women; Newton 2006: MD 2.35 flushes per day; 95\% CI 1.45 to 3.25 flushes per day; 112 women; Geller 2009: MD 26.42 flushes per week; 95\% CI 18.59 to 34.25 flushes per week; P < 0.00001 ; 44 women) (Analysis 2.1; Analysis 2.2).

1.1.2 Intensity of hot flushes

Pooled data for the two trials comparing the intensity of hot flushes for black cohosh and HT (Bai 2007; Geller 2009) were not presented as heterogeneity was high $\left(\mathrm{I}^{2}=98 \%\right)$. In one trial (Geller 2009), the difference in the mean intensity of hot flushes between treatment groups was statistically significant (MD 1.50; 95\% CI 1.05 to 1.95 ; $\mathrm{P}<0.00001$; 44 women), in favour of HT. In the other much larger trial (Bai 2007), there was no statistically significant difference between treatment groups for this outcome (MD $0.07 ; 95 \%$ CI -0.10 to $0.24 ; \mathrm{P}=0.41 ; 238$ women) (Analysis 2.3 ).

\subsection{Night sweats}

\subsubsection{Frequency of night sweats}

One trial (Newton 2006) compared black cohosh to HT; the difference in the mean number of night sweats per day between treatment groups was statistically significant (MD 0.93; 95\% CI 0.47 to $1.39 ; \mathrm{P}<0.0001 ; 112$ women; one trial) (Analysis 2.4), in favour of HT.

1.2.2 Intensity of night sweats

No study reported intensity of night sweats.

\section{Change in frequency or intensity of vulvovaginal symptoms}

Vulvovaginal symptoms were assessed in two trials of black cohosh versus HT (Stoll 1987; Wuttke 2003). One reported vaginal bleeding (Wuttke 2003) and one reported vaginal pruritus (Stoll 1987). However, data were insufficient for analysis.

\section{Menopausal symptom score}

Five studies reported data suitable for meta-analysis. Three studies used the KI (Bai 2007; Geller 2009; Lehmann-Willenbrock 1988), 
two used the GCS (Geller 2009; Nappi 2005), and one used the Wiklund Menopause Symptom Score (Newton 2006). Pooling data for all studies showed a statistically significant difference in menopausal symptom scores between black cohosh and HT, in favour of HT (SMD 0.32; 95\% CI 0.13 to $0.51 ; \mathrm{P}=0.0009 ; 468$ women; five trials) (Analysis 2.5; Figure 6).

Figure 6. Forest plot of comparison: 2 Black cohosh versus hormone therapy, outcome: 2.5 Menopausal Symptom Score.

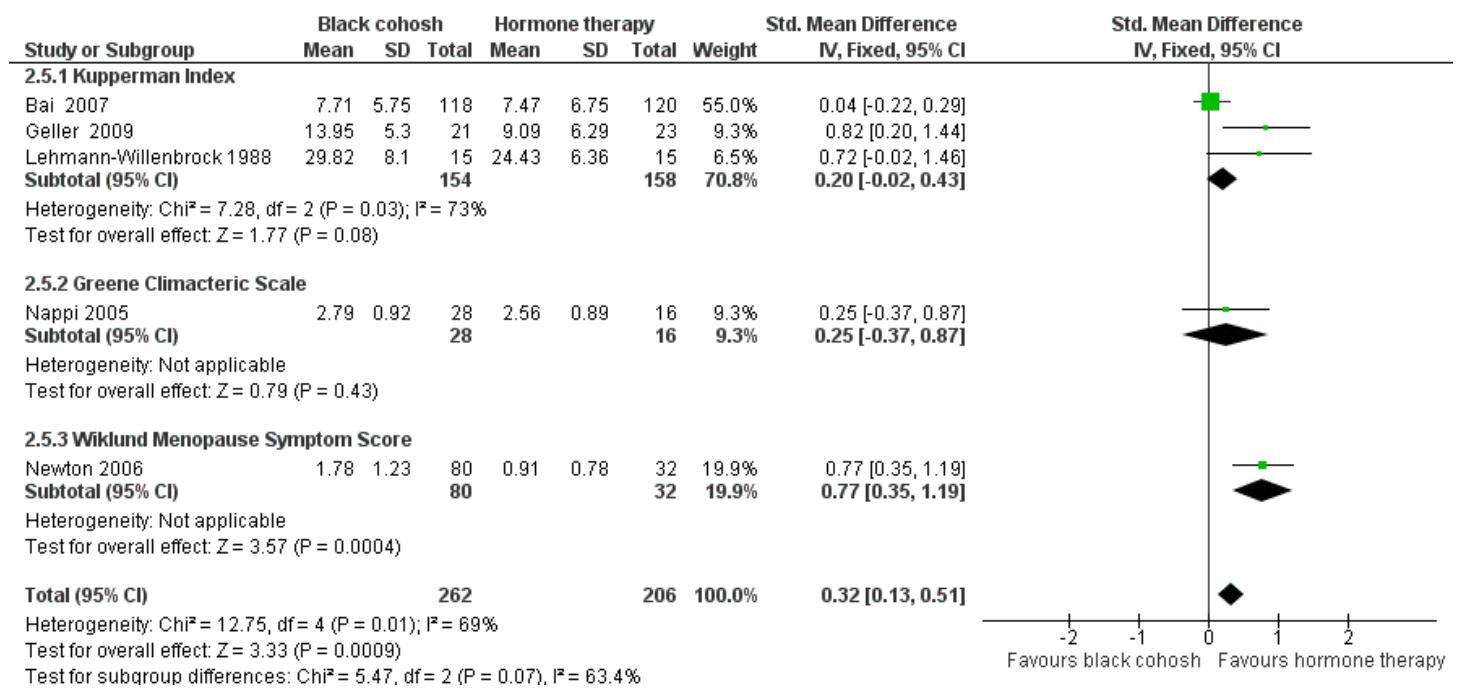

Note that one trial (Geller 2009) reported results for two scales. For this analysis, results for only one scale were used at a time; when GCS scores were used instead of KI scores, the overall effect was marginally reduced (SMD $0.22 ; 95 \%$ CI 0.03 to $0.41 ; \mathrm{P}=$ 0.02; 468 women; five trials).

While the direction of effects across studies were consistent, and the CIs overlapped, there was substantial heterogeneity between studies $\left(\mathrm{I}^{2}=69 \%\right)$. Using a random-effects model, the difference between groups remained statistically significant and the overall effect was marginally increased (SMD $0.48 ; 95 \%$ CI 0.09 to 0.87 ; $\mathrm{P}=0.02$; 468 women; five trials). One factor that might account for the heterogeneity was that each menopausal symptom score measured slightly different symptoms. It was not possible to explore the causes of the heterogeneity any further as there were insufficient data to conduct meaningful subgroup analyses.

Two studies reported data that were not suitable for meta-analysis (Stoll 1987; Wuttke 2003).

\section{Adverse effects}

Four trials (461 women) compared black cohosh to HT (Bai 2007; Nappi 2005; Newton 2006; Wuttke 2003). A total of 202 adverse events were reported in 253 women ( 0.80 events/person) assigned to black cohosh and 304 events in 208 women (1.46 events/person) assigned to HT. One trial reported on the number of women experiencing adverse events (Wuttke 2003); three women reported adverse events among 20 women randomised to black cohosh, compared to four in 22 women randomised to HT. The difference between groups was not statistically significant (RR 0.82; 95\% CI 0.21 to 3.24; $\mathrm{P}=0.78$; 42 women; one trial) (Analysis 2.6).

\section{Secondary outcomes}

\section{Health-related quality of life}

No studies of black cohosh versus HT reported HRQoL.

\section{Sexuality}

One trial reported on sexuality (Stoll 1987) but these data were incomplete and the outcome was not defined. 


\section{Bone health}

One trial (62 women) measuring ALP and telopeptides of type 1 collagen (Wuttke 2003) reported a statistically significant increase in serum ALP after black cohosh treatment when compared with oestrogen, but no difference between black cohosh and controls in the levels of telopeptides of type 1 collagen.

\section{Cost-effectiveness}

No studies of black cohosh versus HT reported cost-effectiveness.

\section{Black cohosh versus red clover (trifolium pratense)}

\section{Primary outcomes}

\section{Change in frequency or intensity of vasomotor symptoms}

\subsection{Hot flushes}

\subsubsection{Frequency of hot flushes}

One trial reported the frequency of hot flushes (Geller 2009); the difference in the mean number of hot flushes per week between the black cohosh and red clover groups was not statistically significant (MD 9.38; 95\% CI -1.04 to $19.80 ; \mathrm{P}=0.08 ; 49$ women; one trial) (Analysis 3.1)

1.1.2 Intensity of hot flushes

One trial reported the intensity of hot flushes (Geller 2009); the difference in the mean intensity of hot flushes between the black cohosh and red clover groups was not statistically significant (MD 0.42 ; $95 \%$ CI -0.08 to $0.92 ; \mathrm{P}=0.10 ; 50$ women; one trial) (Analysis 3.2).

\subsection{Night sweats}

No trials reported on night sweats.

\section{Change in frequency or intensity of vulvovaginal symptoms}

One trial reported vulvovaginal symptoms (Geller 2009) and assessed vaginal dryness. However, data were insufficient for analysis.

\section{Menopausal symptom score}

One trial compared black cohosh to red clover using KI (Geller 2009). The difference in mean KI scores between treatment groups was not statistically significant (MD -1.28; $95 \% \mathrm{CI}-5.48$ to 2.92; $\mathrm{P}=0.55$; 51 women; one trial) (Analysis 3.3).

\section{Adverse effects}

No studies reported adverse effects.

\section{Secondary outcomes}

No trials of black cohosh versus red clover reported on HRQoL, sexuality, bone health or cost-effectiveness as endpoints.

\section{Black cohosh versus fluoxetine}

\section{Primary outcomes}

1. Change in frequency or intensity of vasomotor symptoms

\subsection{Hot flushes}

No studies reported hot flushes.

\subsection{Night sweats}

One trial (Oktem 2007) demonstrated a statistically significant difference in monthly night sweat score (frequency x severity) between black cohosh and fluoxetine groups (MD -85.00; 95\% CI -132.50 to $-37.50 ; \mathrm{P}=0.0005 ; 80$ women; one trial) (Analysis 4.1 ), in favour of black cohosh.

\section{Change in frequency or intensity of vulvovaginal symptoms}

No studies reported vulvovaginal symptoms.

\section{Menopausal symptom score}

One trial compared black cohosh to fluoxetine using KI (Oktem 2007); the difference in mean KI scores between treatment groups was statistically significant (MD $-5.50 ; 95 \%$ CI -8.86 to -2.14 ; P $=0.001 ; 80$ women; one trial) (Analysis 4.2), in favour of black cohosh.

\section{Adverse effects}

One trial (80 women) compared black cohosh to fluoxetine (Oktem 2007). Seven adverse events were reported in 40 women ( 0.2 events/person) assigned to black cohosh, and 13 events in 40 women ( 0.3 events/person) assigned to fluoxetine. The number of women experiencing adverse events (as opposed to the total number of events recorded) was not reported. 


\section{Secondary outcomes}

No trials of black cohosh versus fluoxetine reported on HRQoL, sexuality, bone health or cost-effectiveness as endpoints.

\section{Subgroup and sensitivity analyses}

There were too few studies to perform any of the planned subgroup and sensitivity analyses.

\section{ISCUSSIO N}

\section{Summary of main results}

This systematic review of black cohosh for menopausal symptoms collated information from 16 RCTs, involving a total of 2027 perimenopausal and postmenopausal women. All trials administered oral monopreparations of black cohosh (C. racemosa) in either tablet or capsule form, at a median daily dose of $40 \mathrm{mg}$, for a mean duration of 23.4 weeks. Eleven studies compared black cohosh to placebo, and eight studies compared black cohosh to an active control (e.g. HT, other herbal medicine, other pharmaceutical agent).

While most trials assessed the effect of black cohosh on vasomotor symptoms, the outcome measures used to assess changes in the frequency and intensity of vasomotor symptoms were diverse and often not suitable for statistical pooling. The high level of heterogeneity between studies also does not allow any conclusions to be made about the effectiveness of black cohosh for vasomotor symptoms of menopause. In most cases the causes of the heterogeneity could not be explained; possible factors contributing to the heterogeneity may become apparent when the results of future/ongoing trials become available.

A number of different standardised menopausal symptom scores/ scales/indices (i.e. scores deriving numerical results from a combination of menopausal symptoms) were used in included trials. Few studies shared the same outcome measure. Meta-analysis of pooled menopausal symptom scores did not find black cohosh to be any more effective than placebo. Analysis did indicate that black cohosh may be less effective than HT in reducing menopausal symptom scores and frequency of hot flushes, though this should be interpreted with caution given the substantial heterogeneity between studies. Causes of the heterogeneity could not be explained. There were insufficient data to determine the effects of black cohosh on vulvovaginal atrophic symptoms, HRQoL, sexual dysfunction and bone health. This was primarily because of incomplete reporting. The cost-effectiveness of black cohosh treatment also remains unclear as no study performed an economic evaluation of the treatment.

Ten trials reported any adverse events for 1263 women ( Amsterdam 2009; Bai 2007; Frei-Kleiner 2005; Jacobson 2001;
Kronenberg 2009; Nappi 2005; Newton 2006; Oktem 2007; Osmers 2005; Wuttke 2003). A total of 852 adverse events were reported; 340 events in 623 women treated with black cohosh $(0.55$ events/person), 304 events in 208 women treated with HT (1.46 events/person), 195 events in 392 women treated with placebo ( 0.50 events/person) and 114 events in 195 women treated with other agents ( 0.59 events/person). Adverse effects most frequently reported for black cohosh were breast pain/enlargement, infection, vaginal bleeding/spotting, musculoskeletal complaints and gastrointestinal upset. Women receiving HT were most likely to report breast pain/enlargement, vaginal bleeding/spotting, leucorrhoea, abdominal pain, gastrointestinal upset and menstrual disorders. Adverse effects associated with placebo treatment included infection, gastrointestinal upset, menstrual disorders, musculoskeletal complaints and headache (see Table 5 and Table 6). The incidence of adverse events experienced by women treated with black cohosh ( 0.6 events/person) was similar to that reported by women receiving placebo ( 0.5 events/person), while HT was associated with more than twice the rate of adverse events (1.5 events/person) than black cohosh ( 0.8 events/person). While this could indicate that black cohosh is relatively safe, this finding should be interpreted with caution as event/person data can be potentially skewed by individuals reporting multiple events. Analyses of the number of women experiencing adverse events in each group found no significant difference between groups; although, few studies reported this outcome.

In summary, there is insufficient evidence to either support or oppose the use of black cohosh for menopausal symptoms.

\section{Overall completeness and applicability of evidence}

The objective of this review was to evaluate the effects of black cohosh in perimenopausal and postmenopausal women. Important clinical outcomes typically assessed in menopause research include frequency and intensity of vasomotor symptoms (e.g. hot flushes, night sweats), vulvovaginal symptoms, menopausal symptom scores, sexuality, bone health and adverse effects of treatment. Few trials in this review reported all of these outcomes. Equally important measures such as HRQoL and costs were measured in four and zero studies, respectively. The range of dosages (i.e. 8 to $160 \mathrm{mg}$ daily) and wide range of intervention periods (i.e. four to 52 weeks) also made comparisons difficult. Further, many of the studies reporting to have measured the aforementioned outcomes either did not report the data, or provided data that was insufficient for meta-analysis. In terms of applicability, the studies included in this review have limited external validity owing to the extensive exclusion criteria used in most trials; however, the evidence does suggest that the intervention is probably safe and feasible to implement in clinical practice. 


\section{Quality of the evidence}

Conclusions about the quality of the evidence for black cohosh for menopausal symptoms are constrained by inadequate reporting of study methods. Figure 3 details the review authors' judgments of the methodological quality of the trials included in this review. In the majority of included trials, there was a lack of detail with regard to random sequence generation, allocation concealment, handling of incomplete outcome data, reporting of outcomes and participant withdrawals. Thus, for most studies, the presence of selection bias, reporting bias and attrition bias cannot be excluded. The quality of the evidence is also impacted by the unexplained high level of heterogeneity between studies, and the paucity of data on the number of women experiencing adverse events. Using GRADE criteria, the quality of the body of evidence for comparison of black cohosh versus placebo was rated as moderate for effectiveness outcomes and low for safety outcomes. See Summary of findings for the main comparison

\section{Potential biases in the review process}

There are several limitations to this review that should be noted. Firstly, while the search strategy was comprehensive, and no limits were placed on language of publication, it is possible that pertinent unpublished reports or studies published in languages other than English could have been missed, unintentionally. Thus, language and publication bias cannot be excluded entirely. Secondly, the degree of rigour with which the studies were conducted is not clear; because, even though the risk of bias of most included studies was rated moderate, much of this risk was attributed to inadequate reporting, including the lack of detailed information on allocation concealment, randomisation and participant withdrawals.

\section{Agreements and disagreements with other studies or reviews}

While several reviews of black cohosh have been conducted previously (Borrelli 2008a; Dog 2005), this is the most comprehensive systematic review and meta-analysis investigating the effectiveness of black cohosh monopreparations for menopausal symptoms. The main results of this review reciprocate the findings of previous reviews limited to monopreparations of black cohosh, including concerns about the lack of consistent findings across studies, variations in herbal preparations and dosage, heterogeneity across studies, and methodological shortcomings. In terms of the relative safety of black cohosh, findings from this review are in concordance with the conclusions of earlier reviews. So, even with the inclusion of additional studies, we are still unable to formulate any firm conclusions about the efficacy of black cohosh for menopausal symptoms.

\section{AUTHORS' CONCLUSIONS}

\section{Implications for practice}

This review is unable to draw any conclusions about the effect of orally administered monopreparations of black cohosh ( $C$. racemosa; at doses ranging from 8 to $160 \mathrm{mg}$ daily, for periods varying between four and 52 weeks) on the frequency and intensity of vasomotor symptoms, or global changes in menopausal symptom scores. The effect of black cohosh on vulvovaginal atrophic symptoms, HRQoL, sexuality and bone health is inconclusive also. No evidence was found that black cohosh was associated with more risk of harm than placebo, but there was insufficient good evidence to reach a firm conclusion on safety. Thus, the continued use of black cohosh for the management of menopausal symptoms is not supported by the best available evidence. What is unclear is whether the effect of black cohosh on menopausal symptoms is likely to be any different using other routes of administration or types of preparation.

\section{Implications for research}

In view of the heterogeneity across studies, inadequate reporting of study methods and the wide range of outcome measures used, there is sufficient justification for conducting further research on black cohosh for menopausal symptoms. Such studies need to give adequate attention to the minimum reporting requirements for RCTs (as outlined in the CONSORT statement), particularly with regards to allocation concealment, randomisation and participant withdrawals. Future studies might also want to consider examining the effects of black cohosh on other important outcomes, such as HRQoL, sexuality and bone health, as well as the costeffectiveness of black cohosh treatment. Given that reporting of adverse event/person data can be potentially misleading, it is also important that future studies report the number of women experiencing adverse events. What is also warranted is greater consistency in outcome measures used, with increasing preference for standardised measures.

\section{ACKNOWLEDGEMENTS}

None. 


\section{R E F E R E NCES}

\section{References to studies included in this review}

Amsterdam 2009 \{published and unpublished data\}

* Amsterdam JD, Yao Y, Mao JJ, Soeller I, Rockwell K, Shults J. Randomised, double-blind, placebo-controlled trial of Cimicifuga racemosa (black cohosh) in women with anxiety disorder due to menopause. Journal of Clinical Psychopharmacology 2009;29(5):478-83.

Bai 2007 \{published and unpublished data\}

Bai W, Henneicke-von Zepelin HH, Wang S, Zheng S, Liu J, Zhang Z, et al. Efficacy and tolerability of a medicinal product containing an isopropanolic black cohosh extract in Chinese women with menopausal symptoms: a randomized, double blind, parallel-controlled study versus tibolone. Maturitas 2007;58(1):31-41.

Bebenek 2010 \{published data only\}

Bebenek M, Kemmler W, von Stengel S, Engelke K, Kalender WA. Effect of exercise and Cimicifuga racemosa (CR BNO 1055) on bone mineral density, 10-year coronary heart disease risk, and menopausal complaints: the randomized controlled Training and Cimicifuga racemosa Erlangen (TRACE) study. Menopause 2010;17(4):791-800.

Carlisle 2008 \{published data only\}

Carlisle A, Jessup JV. Effect of black cohosh on biochemical markers of bone remodeling in postmenopausal women. Dissertation, University of Florida, USA, 2008.

Frei-Kleiner 2005 \{published and unpublished data\} Frei-Kleiner S, Schaffner W, Rahlfs VW, Bodmer CH, Birkhauser M. Cimicifuga racemosa dried ethanolic extract in menopausal disorders: a double-blind placebo-controlled clinical trial. Maturitas 2005;51(4):397-404.

Geller 2009 \{published and unpublished data\}

Geller SE, Shulman LP, van Breemen RB, Banuvar S, Zhou Y, Epstein G, et al. Safety and efficacy of black cohosh and red clover for the management of vasomotor symptoms: a randomised controlled trial. Menopause 2009;16(6): 1156-66.

Jacobson 2001 \{published and unpublished data\} Jacobson JS, Troxel AB, Evans J, Klaus L, Vahdat L, Kinne $\mathrm{D}$, et al. Randomized trial of black cohosh for the treatment of hot flashes among women with a history of breast cancer. Journal of Clinical Oncology 2001;19(10):2739-45.

Kronenberg 2009 \{published and unpublished data\} Kronenberg F, Warren M, Coleton M, Jin Z, McMahon DJ, Sauberli W. Effect of black cohosh extract on hot flashes and other menopausal symptoms. Poster presentation, 20th Annual Meeting, North American Menopause Society, San Diego, CA 2009.

Lehmann-Willenbrock 1988 \{published data only\} Lehmann-Willenbrock WE, Riedel HH. Clinical and endocrinologic examinations about therapy of climacteric symptoms following hysterectomy with remaining ovaries [Klinische und endokronologische untersuchungen zur therapie ovarieller ausfallserscheinungen nach hysterektomie unter belassung der adnexe]. Zentralblatt für Gynäkologie 1988;110(10):611-8.

Nappi 2005 \{published and unpublished data\} Nappi RE, Malavasi B, Brundu B, Facchinetti F. Efficacy of Cimicifuga racemosa on climacteric complaints: a randomized study versus low-dose transdermal estradiol. Gynecological Endocrinology 2005;20(1):30-5.

Newton 2006 \{published and unpublished data\} Newton KM, Reed SD, LaCroix AZ, Grothaus LC, Ehrlich K, Guiltinan J. Treatment of vasomotor symptoms of menopause with black cohosh, multibotanicals, soy, hormone therapy, or placebo: a randomized trial. Annals of Internal Medicine 2006;145(12):869-79.

Reed SD, Newton KM, LaCroix AZ, Grothaus LC, Grieco VS, Ehrlich K. Vaginal, endometrial, and reproductive hormone findings: randomized, placebo-controlled trial of black cohosh, multibotanical herbs, and dietary soy for vasomotor symptoms: the Herbal Alternatives for Menopause (HALT) Study. Menopause 2008;15(1):51-8.

Oktem 2007 \{published data only\} Oktem M, Eroglu D, Karahan HB, Taskintuna N, Kuscu E, Zeyneloglu HB. Black cohosh and fluoxetine in the treatment of postmenopausal symptoms: a prospective, randomized trial. Advances in Therapy 2007;24(2):448-61.

Osmers 2005 \{published data only\}

Osmers R, Friede M, Liske E, Schnitker J, Freudenstein J, Henneicke-von, et al. Efficacy and safety of isopropanolic black cohosh extract for climacteric symptoms. Obstetrics \& Gynecology 2005;105(5):1074-83

Pockaj 2006 \{published and unpublished data\} Pockaj BA, Gallagher JG, Loprinzi CL, Stella PJ, Barton DL, Sloan JA, et al. Phase III double-blind, randomized, placebo-controlled crossover trial of black cohosh in the management of hot flashes: NCCTG Trial N01CC1. Journal of Clinical Oncology 2006;24(18):2836-41.

Stoll 1987 \{published data only\}

Stoll W. Phytopharmacon influences atrophic vaginal epithelium: double blind study: cimicifuga vs. estrogenic substances [Phytotherapeutikum beeinfluBt atrophisches vaginalepithel: doppelblindversuch cimicifuga vs ostrogenpraparat]. Therapeutikum 1987;1:23-31.

Wuttke 2003 \{published data only\}

Wuttke W, Gorkow C, Seidlová-Wuttke D. Effects of black cohosh (Cimicifuga racemosa) on bone turnover, vaginal mucosa, and various blood parameters in postmenopausal women: a double-blind, placebo-controlled, and conjugated estrogens-controlled study. Menopause 2006a;13(2): $185-96$.

Wuttke W, Raus K, Gorkow C. Efficacy and tolerability of the Black cohosh (Actaea racemosa) ethanolic extract BNO 1055 on climacteric complaints: a double-blind, placebo- 
and conjugated estrogens-controlled study. Maturitas 2006b;55(Suppl 1):S83-91.

Wuttke W, Seidlova-Wuttke D, Gorkow C. The Cimicifuga preparation BNO 1055 vs. conjugated estrogens in a double-blind placebo-controlled study: effects on menopause symptoms and bone markers. Maturitas 2003; 44(Suppl 1):S67-77.

\section{References to studies excluded from this review}

Blohmer 2007 \{published data only\}

Blohmer JU, Graubaum HJ, Busch R, Grunwald J, Wernecke KD, Uebelhack R. Cimicifuga and Hypericum as a fixed combination against climacteric complaints. A randomised controlled trial. Zeitschrift fur Phytotherapie 2007;28(2):67-70.

Chung 2007 \{published data only\} Chung DJ, Kim HY, Park KH, Jeong KA, Lee SK, Le YI, et al. Black cohosh and St. John's wort (GYNO-Plus) for climacteric symptoms. Yonsei Medical Journal 2007;48(2): 289-94.

Liske 2002 \{published data only\}

Liske E, Hanggi W, Henneicke-von Zepelin HH, Boblitz N, Wustenberg P, Rahlfs VW. Physiological investigation of a unique extract of black cohosh (Cimicifugae racemosae rhizome): a 6-month clinical study demonstrates no systemic estrogenic effect. Journal of Women's Health \& Gender-Based Medicine 2002;11(2):163-74.

Myoung 2008 \{published data only\}

Myoung-Suk N, Young-Lim O, Heung-Yeol K, WanKyo E, Hong-Bae K. The effects of black cohosh root extract on the vasomotor symptom and bone metabolism of postmenopausal women. Korean Journal of Bone Metabolism 2008;15(2):155-62.

Park 2006 \{published data only\}

Park HM, Kim JG, Yoon BK, Lee BI, Choi H, Seo SH. The effect of black cohosh with St. John's wort (Feramin-Q) on climacteric symptoms: multicenter randomised doubleblind placebo-controlled trial. Korean Journal of Obstetrics \& Gynecology 2006;48(10):2403-13.

Rotem 2007 \{published data only\}

Rotem C, Kaplan B. Phyto-Female Complex for the relief of hot flushes, night sweats and quality of sleep: randomised, controlled, double-blind pilot study. Gynecological Endocrinology 2007;23(2):117-22.

Sammartino 2006 \{published data only\} Sammartino A, Tommaselli GA, Gargano V, di Carlo C, Attianese W, Nappi C. Short term effects of a combination of isoflavones, lignans and Cimicifuga racemosa on climacteric-related symptoms in postmenopausal women: a double-blind, randomised, placebo-controlled trial. Gynecological Endocrinology 2006;22(11):646-50.

Uebelhack 2006 \{published data only\} Uebelhack R, Blohmer JU, Graubaum HJ, Busch R, Gruenwald J, Wernecke KD. Black cohosh and St. John's wort for climacteric complaints: a randomised trial. Obstetrics \& Gynecology 2006;107(2 Pt 1):247-55.
Verhoeven 2005 \{published data only\}

Verhoeven MO, van der Mooren MJ, van de Weijer PH, Verdegem PJ, van der Burgt LM, Kenemans P. Effect of a combination of isoflavones and Actaea racemosa Linnaeus on climacteric symptoms in healthy symptomatic perimenopausal women: a 12-week randomised, placebocontrolled, double-blind study. Menopause 2005;12(4): 412-20.

\section{References to studies awaiting assessment}

\section{Aly 2009 \{published data only\}}

Aly M. Use of black cohosh (Cimicifuga racemosa) in postmenopausal women: a randomized controlled study. International Journal of Gynecology and Obstetrics 2009;107 (Suppl 2):S646.

\section{Kim 2009 \{published data only\}}

Kim HY, Choi H, Park HM, Lee BS, Kang BM, Yoon $\mathrm{BK}$, et al. The effects of black cohosh root extract on the vasomotor symptom and bone metabolism of menopausal women. Maturitas 2009;63(Suppl 1):S75.

\section{References to ongoing studies}

Vichinsartvichai 2012 \{published data only\}

Black Cohosh Extract for the Management of Moderate to Severe Menopausal Symptoms in Thai Women. Ongoing study December 2011.

\section{Additional references}

\section{ADEC 2004}

Australian Drug Evaluation Committee (ADEC). ADEC Summary Statement on HRT. Canberra: Therapeutic Goods Administration, 2004.

\section{Blumel 2000}

Blumel JE, Castelo-Branco C, Binfa L, Gramegna G, Tacla $\mathrm{X}$, Aracena B, et al. Quality of life after the menopause: a population study. Maturitas 2000;34(1):17-23.

Blumenthal 2003

Blumenthal M. The ABC Clinical Guide to Herbs. Austin: American Botanical Council, 2003.

\section{Borrelli 2003}

Borrelli F, Izzo AA, Ernst E. Pharmacological effects of Cimicifuga racemosa. Life Sciences 2003;73(10):1215-29.

\section{Borrelli 2008a}

Borrelli F, Ernst E. Black cohosh (Cimicifuga racemosa) for menopausal symptoms: a systematic review of its efficacy. Pharmacological Research 2008;58(1):8-14.

\section{Borrelli 2008b}

Borrelli F, Ernst E. Black cohosh (Cimicifuga racemosa): a systematic review of adverse events. American Journal of Obstetrics \& Gynecology 2008;199(5):455-66.

\section{Corwin 2008}

Corwin EJ. Handbook of Pathophysiology. Philadelphia: Lippincott, Williams \& Wilkins, 2008. 
Dog 2005

Dog TL. Menopause: a review of botanical dietary supplements. The American Journal of Medicine 2005;118 (Suppl 2):98S-108S.

\section{Farquhar 2005}

Farquhar CM, Marjoribanks J, Lethaby A, Lamberts Q, Suckling JA, Cochrane HT Study Group. Long term hormone therapy for perimenopausal and postmenopausal women. Cochrane Database of Systematic Reviews 2005, Issue 3. DOI: 10.1002/14651858.CD004143.pub3

\section{Gabriel-Sánchez 2005}

Gabriel-Sánchez R, Carmona L, Roque M, SánchezGómez LM, Bonfill X. Hormone replacement therapy for preventing cardiovascular disease in post-menopausal women. Cochrane Database of Systematic Reviews 2005, Issue 2. DOI: 10.1002/14651858.CD002229.pub2

\section{Higgins 2002}

Higgins JPT, Thompson SG. Quantifying heterogeneity in a meta-analysis. Statistics in Medicine 2002;21:1539-58.

\section{Higgins 2011}

Higgins JPT, Green S (editors). Cochrane Handbook for Systematic Reviews of Interventions Version 5.1.0 [updated March 2011]. The Cochrane Collaboration, 2011. Available from www.cochrane-handbook.org.

\section{Keville 1991}

Keville K. The Illustrated Herb Encyclopedia. East Roseville: Simon \& Shuster Australia, 1991.

\section{MacLennan 2004}

MacLennan AH, Broadbent JL, Lester S, Moore V. Oral oestrogen and combined oestrogen/progestogen therapy versus placebo for hot flushes. Cochrane Database of Systematic Reviews 2004, Issue 4. DOI: 10.1002/ 14651858.CD002978.pub2

\section{McKinlay 1992}

McKinlay SM, Brambilla DJ, Posner JG. The normal menopause transition. American Journal of Human Biology 1992;4(1):37-46.

\section{Mills 2000}

Mills S, Bone K. Principles and Practice of Phytotherapy: Modern Herbal Medicine. Edinburgh: Churchill Livingstone, 2000.

\section{Mishra 2006}

Mishra G, Kuh D. Perceived change in quality of life during the menopause. Social Science \& Medicine 2006;62(1): 93-102.

\section{Peeyananjarassri 2005}

Peeyananjarassri K, Baber R. Effects of low-dose hormone therapy on menopausal symptoms, bone mineral density, endometrium, and the cardiovascular system: a review of randomized clinical trials. Climacteric 2005;8(1):13-23.

\section{Porter 2011}

Porter RS, Kaplan JL. The Merck Manual Online. Whitehouse Station, New Jersey: Merck Research Laboratories, 2011.

\section{RevMan 2011 [Computer program]}

The Nordic Cochrane Centre, The Cochrane Collaboration. Review Manager (RevMan). Version 5.1. Copenhagen: The Nordic Cochrane Centre, The Cochrane Collaboration, 2011.

\section{Roberts 2010}

Roberts H. Safety of herbal medicinal products in women with breast cancer. Maturitas 2010;66(4):363-369.

\section{Rossouw 2002}

Rossouw JE, Anderson GL, Prentice RL, LaCroix AZ, Kooperberg C, Stefanick ML, et al. Risks and benefits of estrogen plus progestin in healthy postmenopausal women. Journal of the American Medical Association 2002;288(3): 321-33.

* Indicates the major publication for the study 


\title{
CHARACTERISTICSOF STUDIES
}

\section{Characteristics of included studies [ordered by study ID]}

\author{
Amsterdam 2009
}

Methods

Design: randomised, double-blind, placebo-controlled, parallel group trial

Randomisation ratio: not stated

Study duration: 3.5 years (from January 2006 to June 2008)

Participants

Participant characteristics: 34 women enrolled, 28 were randomised (black cohosh $=15$, placebo $=13)$ and $7(25 \%)$ dropped out. Mean age (black cohosh $=56.7 \pm 6.5$ years, placebo $=50.8 \pm 3.2$ years). Duration of menopause not stated

Inclusion criteria: female, aged $\geq 40$ years, postmenopausal for $\geq 12$ months or perimenopausal (amenorrhoea lasting 2 to 11 months in the preceding year). Onset of anxiety symptoms occurred within 3 years of onset of menopause or perimenopause or < 5 years after cessation of menstruation. Women with prior hysterectomy and uncertain menopausal status required a serum $\mathrm{FSH} \geq 40 \mathrm{mIU} / \mathrm{mL}$

Exclusion criteria: major depressive disorder, bipolar disorder, panic disorder, phobic disorder, obsessive-compulsive disorder, post-traumatic stress disorder, acute stress disorder, substance-induced anxiety disorder, schizophrenia, dementia, substance abuse or dependence disorder within the past 3 months; unstable medical condition, hepatic or renal disease, malignancy, serum thyrotropin level $\geq 5 \mu \mathrm{IU} / \mathrm{mL}$, abnormal breast examination or mammogram result, history of endometrial hyperplasia or endometrial cancer, rapidly growing uterine leiomyomata, undiagnosed abnormal uterine bleeding, abnormal gynaecological examination result precluding use of black cohosh, known sensitivity to black cohosh; and concurrent use of prescribed anxiolytics, antidepressants, mood stabilisers, sedatives, complementary medicines (e.g. St. John's Wort), oral oestrogen, oestrogen cream, and phyto-oestrogen preparations

Diagnostic criteria: DSM-IV Axis I diagnosis of anxiety disorder owing to menopause

Co-morbidities: not stated

Co-medications: not stated

Interventions

Number of study centres: not stated

Country/location: Philadelphia, Pennsylvania, US

Setting: not stated

Intervention (route, total, dose/day, frequency): oral ethanolic extract of Cimicifuga racemosa 32 to $128 \mathrm{mg}$ ( $32 \mathrm{mg}$, standardised to $5.6 \%$ triterpene glycosides), 1 to 4 capsules daily

Control (route, total, dose/day, frequency): oral rice flour, 1 to 4 capsules daily

Duration of intervention: 12 weeks

Duration of follow-up: not applicable

Run-in period: not applicable

Treatment before study: not stated

Titration period: treatment began at 2 capsules daily for 2 weeks. Dose was increased to 4 capsules daily by study week 4 in women with $\leq 50 \%$ reduction in total Hamilton Anxiety Rating Scale Score 


\section{Risk of bias}

\begin{tabular}{|c|c|c|}
\hline Bias & Authors' judgement & Support for judgement \\
\hline $\begin{array}{l}\text { Random sequence generation (selection } \\
\text { bias) }\end{array}$ & Low risk & $\begin{array}{l}\text { Quote: "Randomisation was performed us- } \\
\text { ing blocked randomisation with varying } \\
\text { block sizes" } \\
\text { Comment: probably done }\end{array}$ \\
\hline Allocation concealment (selection bias) & Unclear risk & $\begin{array}{l}\text { Method of allocation concealment not de- } \\
\text { scribed } \\
\text { Comment: probably not done }\end{array}$ \\
\hline $\begin{array}{l}\text { Blinding (performance bias and detection } \\
\text { bias) } \\
\text { All outcomes }\end{array}$ & Unclear risk & $\begin{array}{l}\text { Quote: "All study subjects and outcome } \\
\text { raters were blinded as to treatment condi- } \\
\text { tion, and all results were analysed under } \\
\text { blinded conditions..."; though there was no } \\
\text { assurance that interventions matched in ap- } \\
\text { pearance, taste or odour } \\
\text { Comment: probably done }\end{array}$ \\
\hline $\begin{array}{l}\text { Incomplete outcome data (attrition bias) } \\
\text { All outcomes }\end{array}$ & Low risk & $\begin{array}{l}\text { "Intention-to-treat" (which assumed that } \\
\text { those who withdrew were non-responders) }\end{array}$ \\
\hline Selective reporting (reporting bias) & Unclear risk & $\begin{array}{l}\text { All primary and secondary outcomes listed } \\
\text { were reported, though no study protocol } \\
\text { was published or lodged }\end{array}$ \\
\hline Other bias & Unclear risk & $\begin{array}{l}\text { Baseline differences in age and duration of } \\
\text { illness were evident }\end{array}$ \\
\hline
\end{tabular}

Bai 2007

Methods

Participants
Design: randomised, double-blind, active-controlled, double-dummy, multicentre, parallel group trial

Randomisation ratio: 1:1

Study duration: 9 months (from September 2004 to May 2005)

Participant characteristics: 244 women enrolled, 244 were randomised (black cohosh = 122 , tibolone $=122)$ and $26(10.7 \%)$ dropped out. Mean age (black cohosh $=51.8 \pm 3$. 7 years, tibolone $=51.5 \pm 3.5$ years). Duration of amenorrhoea (black cohosh $=32.2 \pm$ 24.6 months, tibolone $=35.4 \pm 25.3$ months)

Inclusion criteria: female, aged between 40 and 60 years, history of menopausal com- 
plaints for at least 4 weeks, spontaneous amenorrhoeic interval $\geq 5$ months since last regular menstruation, baseline $\mathrm{E} 2 \leq 30 \mathrm{pg} / \mathrm{mL}$ if amenorrhoeic $<12$ months, $\mathrm{KI} \geq 15$ Exclusion criteria: HT within the last 4 weeks, psychoactive drugs, BMI $>28 \mathrm{~kg} / \mathrm{m}^{2}$, endometrial thickness $\geq 5 \mathrm{~mm}$ if amenorrhoea $\geq 12$ months or $\geq 15 \mathrm{~mm}$ if $<12$ months, irregular gynaecological bleeding within the last 4 weeks, hysterectomy, amenorrhoea $>8$ years, abnormal cervical smear examination, contraindication of tibolone, cancer, severe or current disease that could interfere with climacteric manifestations or treatment, drug abuse, alcohol addiction, participation in a Phase I or II trial in the last 180 days or a Phase III or IV trial within the last 90 days, and any drug, food, traditional Chinese medicine or nutritional supplement used for climacteric symptoms

Diagnostic criteria: not stated

Co-morbidities: not stated

Co-medications: not stated

Interventions

Number of study centres: 5

Country/location: China

Setting: hospital research centres

Intervention (route, total, dose/day, frequency): oral isopropanolic extract of Cimicifuga racemosa (Remifemin, equivalent to $2.5 \mathrm{mg}$ dry extract or $20 \mathrm{mg}$ C. racemosa root) 2 tablet twice a day, and 2 tibolone-matching placebo tablet daily

Control (route, total, dose/day, frequency): oral tibolone $2.5 \mathrm{mg}$ tablet daily, and $2 \mathrm{C}$. racemosa-matching placebo tablets daily

Duration of intervention: 12 weeks

Duration of follow-up: not applicable

Run-in period: not applicable

Treatment before study: not stated

Titration period: not applicable

Outcomes

Primary outcomes: benefit (i.e. change in KI) to risk (i.e. number of adverse events) balance

Secondary outcomes: total KI score, KI subscale scores, KI responder rate, Clinical Global Impression items, subject's global efficacy of effectiveness

Additional outcomes: vital signs, body weight, concomitant disease, adverse events, endometrial thickness, liver function test, complete blood picture

\section{Risk of bias}

\section{Bias}

Random sequence generation (selection Unclear risk bias)

\section{Authors' judgement}

\section{Support for judgement}

Quote: "All eligible subjects were randomly allocated to the two treatment groups" (method not described)

Comment: probably not done

Method of allocation concealment not described

Comment: probably not done 
Blinding (performance bias and detection Low risk bias)

All outcomes
Quote: “double-blind”; “double dummy"; "patients received two Remifemin ${ }^{\circledR}$ tablets (1-0-1) and one tibolone-matching placebo...the tibolonegroup applied two Remifemin ${ }^{\circledR}$ - matching placebos and one tibolone tablet"

Comment: probably done.

ITT was not mentioned, but the term 'full analysis set' was used; however, "six subjects were excluded from the full analysis set... for discontinuing the trial for any reason" A similar proportion of women withdrew from each group, though the reasons differed

Selective reporting (reporting bias) Unclear risk

All primary and secondary outcomes listed were reported, although no study protocol was published or lodged

\begin{tabular}{ll} 
Other bias $\quad$ Low risk \\
\hline
\end{tabular}

Bebenek 2010

Methods

Design: randomised, double-blind, placebo-controlled, parallel group trial

Randomisation ratio: not stated

Study duration: not stated

Participants
Participant characteristics: 128 women were randomised (exercise + black cohosh $=43$, exercise only $=43$, wellness control $=42)$, and $25(19.5 \%)$ dropped out. Mean age (exercise + black cohosh $=51.8 \pm 2.7$ years, exercise only $=52.3 \pm 2.3$ years, wellness control $=52.4 \pm 2.7$ years). Duration of menopause not stated

Inclusion criteria: female, aged between 48 and 55 years, living in Erlangen-Nuremberg (Germany), 1 to 3 years postmenopausal, Caucasian

Exclusion criteria: thrombosis, embolism, history of profound CHD, lumbar spine or hip fracture, secondary osteoporosis, hyperparathyroidism, medication or diseases that impact on muscle or bone, inflammatory disease, athletic history in the past decade, weight reduction $>5 \mathrm{~kg}$ in the last 6 months

Diagnostic criteria: menopause was defined as self-reported lack of a menstrual cycle for more than 12 months or a LH:FSH ratio $<1.0$

Co-morbidities: not stated

Co-medications: calcium (1.5 g/day) and cholecalciferol supplementation (500 IE/day) was provided to all women 
Bebenek 2010 (Continued)

$\begin{array}{ll}\text { Interventions } & \text { Number of study centres: not stated } \\ \text { Country/location: Erlangen, Germany } \\ \text { Setting: not stated } \\ \text { Intervention (route, total, dose/day, frequency): exercise ( } 60 \text { minutes, weekly; comprising } \\ 6 \text { weeks of high-intensity-resistance/high-impact exercise dedicated to bone parameters, } \\ \text { interspersed by blocks of } 10 \text { weeks of moderate intensity exercise focusing on parameters } \\ \text { related to CHD) + Cimicifuga racemosa ( } 40 \text { mg daily; } 3 \text { months on then } 3 \text { months off) } \\ \text {; exercise ( } 60 \text { minutes, weekly; comprising } 6 \text { weeks of high-intensity-resistance/high- } \\ \text { impact exercise dedicated to bone parameters, interspersed by blocks of } 10 \text { weeks of } \\ \text { moderate-intensity exercise focusing on parameters related to CHD) + placebo (daily; } 3 \\ \text { months on then } 3 \text { months off) } \\ \text { Control (route, total, dose/day, frequency): wellness control (60 minutes, weekly; com- } \\ \text { prising a low-intensity exercise programme for a period of } 10 \text { weeks, interspersed with } \\ 10 \text {-week blocks without exercise) + placebo (daily; } 3 \text { months on then } 3 \text { months off) } \\ \text { Duration of intervention: } 12 \text { months ( } 52 \text { weeks) } \\ \text { Duration of follow-up: not stated } \\ \text { Run-in period: not stated } \\ \text { Treatment before study: not stated } \\ \text { Titration period: not stated }\end{array}$

Outcomes

Primary outcomes: bone mineral density (lumbar spine, proximal hip), 10-year CHD risk

Secondary outcomes: body composition (total and regional), MRS, aerobic capacity Additional outcomes: not stated

This study reported both final value scores and change-from-baseline scores

\section{Risk of bias}

\section{Bias}

Random sequence generation (selection Low risk bias)

\section{Support for judgement}

Quote: "women were finally assigned by computer-generated block randomisation stratified for menopause age to three subgroups"

Comment: probably done

Allocation concealment (selection bias) Unclear risk

Method of allocation concealment not described

Comment: probably not done

Blinding (performance bias and detection Low risk bias)

All outcomes
Quote: "the study was blinded for research assistants and participants"; "Blinding of the participants was successful in view of the fact that $77 \%$ of the participants in the CG [control group] considered that they were in the primary intervention group"

Comment: probably done 
Bebenek 2010 (Continued)

Incomplete outcome data (attrition bias) High risk All outcomes "intention-to-treat" was quoted, but the final analysis excluded women $(\mathrm{n}=25)$ lost to follow-up

A greater number of women were lost to follow-up in the wellness group when compared to the 2 exercise groups, primarily because women lost interest in the intervention. Other reasons for withdrawal were similar across treatment groups

All primary and secondary outcomes listed were reported, although no study protocol was published or lodged

Other bias Low risk

Design: randomised, double-blind, placebo-controlled, parallel group trial

Randomisation ratio: not stated

Study duration: not stated

Participants

Participant characteristics: 48 women were randomised (black cohosh $=24$, placebo $=$ $24)$, and $2(4.2 \%)$ dropped out. Mean age (black cohosh $=54.1 \pm 5.0$ years, placebo $=$ $52.8 \pm 4.4$ years). Time postmenopausal (black cohosh $=3.7 \pm 1.5$ months, placebo $=$ $2.8 \pm 1.7$ months)

Inclusion criteria: female, Caucasian, aged between 35 and 60 years, had natural or surgical menopausal for at least 1 year but not more than 6 years, able to give voluntary consent, not taking any hormone replacement therapy or SERMs for the past 3 months, had not been diagnosed with osteoporosis or an osteoporosis-related bone fracture, were sedentary and not involved in a regular exercise programme, and had not taken black cohosh for the past 3 months

Exclusion criteria: smoker, lactose intolerant, history of taking bisphosphonates at any time in their life, history of kidney or liver disease, diabetes, parathyroid disease or documented osteoporosis with DEXA scan, failed to take study medication as directed, became ill or were diagnosed with osteoporosis or fracture during the study, changed their mind about being included in the study

Diagnostic criteria: not stated

Co-morbidities: not stated

Co-medications: not stated

Interventions
Number of study centres: not stated

Country/location: North Central Florida, US

Setting: not stated

Intervention (route, total, dose/day, frequency): oral Cimicifuga racemosa (40 mg, standardised to $2.5 \%$ triterpene glycosides) 1 capsule daily; plus calcium carbonate and vi- 
tamin D supplement, 1 caplet twice daily (dosage not described)

Control (route, total, dose/day, frequency): oral placebo (lactose), 1 capsule daily; plus calcium carbonate and vitamin D supplement, 1 caplet twice daily (dosage not described) Duration of intervention: 12 weeks

Duration of follow-up: not applicable

Run-in period: not applicable

Treatment before study: not stated

Titration period: not stated

Primary outcomes: serum C-terminal telopeptide, serum osteocalcin

Secondary outcomes: weight, height, BMI, blood pressure

Additional outcomes: not stated

\section{Notes}

The type of data reported was not clear

\section{Risk of bias}

\section{Bias}

Random sequence generation (selection Low risk bias)

\section{Authors' judgement}

\begin{tabular}{l|l} 
& \\
\hline Allocation concealment (selection bias) & Unclear risk \\
\hline $\begin{array}{l}\text { Blinding (performance bias and detection } \\
\text { bias) }\end{array}$ & Low risk \\
\hline \begin{tabular}{l} 
All outcomes \\
\hline
\end{tabular}
\end{tabular}

All outcomes

\section{Support for judgement}

Quote: “the participant was...randomized into either the experimental or the control group using a computer generated randomization table"

Comment: probably done

Method of allocation concealment not described

Comment: probably not done

Quote: "double-blind"; "the placebo group took an identical appearing placebo capsule"

Comment: probably done

Incomplete outcome data (attrition bias) High risk All outcomes

Unclear risk

All primary and secondary outcomes listed were reported, although no study protocol was published or lodged

Other bias

Unclear risk

ITT was not mentioned

2 women withdrew from the study (1 in each arm) - the reasons for withdrawal differed between groups. Both women were excluded from the analysis by researchers

Selective reporting (reporting bias) Unclear risk

Baseline differences in years postmenopausal was observed 
Frei-Kleiner 2005

Methods

Design: randomised, double-blind, placebo-controlled, multicentre, parallel group trial Randomisation ratio: 2:1 (active:placebo)

Study duration: not stated

Participants

Participant characteristics: 129 women were randomised (black cohosh $=84$, placebo $=$ $45)$, and $20(15.5 \%)$ dropped out. Mean age (black cohosh $=52.5 \pm 3.7$ years, placebo $=52.2 \pm 3.5$ years). Duration of amenorrhoea (black cohosh $=38.7 \pm 50.5$ months, placebo $=37.3 \pm 51.4$ months)

Inclusion criteria: female, early or perimenopause with climacteric disorders, aged between 45 and 60 years, $\geq 3$ hot flushes daily (corresponding to $\geq 42$ hot flushes during the run-in period), $\geq 1$ functioning ovary, normal gynaecological examination

Exclusion criteria: history of breast or endometrial carcinoma, medication affecting menopausal complaints, hormone replacement therapy within the last month, alcohol abuse, drug abuse, serious conditions interfering with study objectives

Diagnostic criteria: not stated

Co-morbidities: not stated

Co-medications: not stated

Interventions

Number of study centres: 14

Country/location: Switzerland

Setting: private gynaecological practices $(\mathrm{n}=12)$ and university menopause centres $(\mathrm{n}=$ 2)

Intervention (route, total, dose/day, frequency): oral ethanolic extract of Cimicifuga racemosa (6.5 mg dry extract or $42 \mathrm{mg}$ crude drug), 1 capsule daily

Control (route, total, dose/day, frequency): oral placebo (excipients only), 1 capsule daily

Duration of intervention: 12 weeks

Duration of follow-up: not applicable

Run-in period: 2 weeks

Treatment before study: not stated

Titration period: not applicable

Outcomes

Primary outcomes: hot flushes (weekly weighted score), KI

Secondary outcomes: MRS, urogenital symptoms, ophthalmic symptoms, serum FSH, karyopyknotic index

Additional outcomes: clinical global impression of efficacy

Notes

This study reported final value scores

\section{Risk of bias}

\section{Bias}

Random sequence generation (selection Unclear risk bias)

Allocation concealment (selection bias)

Unclear risk

\section{Support for judgement}

Quote: "patients were randomized in the ratio of 2:1" (method not described)

Comment: probably done

Method of allocation concealment not described

Comment: probably not done 
Frei-Kleiner 2005 (Continued)

Blinding (performance bias and detection Low risk bias)

All outcomes
Quote: “double-blind”; “one group received capsules of Cimicifuga racemosa extract...and the other group identically appearing placebo capsules"

Comment: probably done
Incomplete outcome data (attrition bias) High risk All outcomes
Used the expression ITT, but "five patients were excluded from the intention-to-treat population because of serious protocol violations or a posteriori detected exclusion criteria"

15 women discontinued the study; however, the number and reasons for withdrawal were not given for each group separately

High risk

While no study protocol was published or lodged, there was limited discussion of many secondary outcome measures

Baseline differences in menopausal status and level of FSH were observed

Geller 2009

Methods

Design: randomised, double-blind, placebo-controlled, multicentre, parallel group trial Randomisation ratio: not stated

Study duration: 50 months (from February 2003 to December 2007)

Participants

Participant characteristics: 89 women were randomised (black cohosh $=22$, red clover $=22, \mathrm{CEO} / \mathrm{MPA}=23$, placebo $=22)$, and $9(10.1 \%)$ dropped out. Mean age (black cohosh $=54.4 \pm 3.9$ years, red clover $=52.4 \pm 4.6$ years, $\mathrm{CEO} / \mathrm{MPA}=53.3 \pm 4.0$ years, placebo $=52.0 \pm 4.2$ years). Duration of amenorrhoea (black cohosh $=3.4 \pm 2.6$ years, red clover $=4.1 \pm 2.8$ years, $\mathrm{CEO} / \mathrm{MPA}=3.6 \pm 2.9$ years, placebo $=2.8 \pm 2.9$ years $)$

Inclusion criteria: female, perimenopausal or postmenopausal with intact uterus, experiencing $\geq 35$ vasomotor symptoms (hot flushes and night sweats) per week, amenorrhoea $>6$ months and $<10$ years' duration, $\mathrm{FSH}>40 \mathrm{mIU} / \mathrm{mL}$, HT not contraindicated Exclusion criteria: hysterectomy, abnormal vaginal bleeding of undetermined aetiology, abnormal transvaginal ultrasound ( $>7 \mathrm{~mm}$ thickness), abnormal endometrial biopsy or mammogram, diabetes, positive pregnancy test, breastfeeding, history of endometrial hyperplasia/neoplasia, breast cancer or cancer of the reproductive tract, history of myocardial infarction, stroke, severe varicose veins, sickle cell anaemia, deep vein thrombosis, thrombophlebitis or thromboembolic disorder, untreated or uncontrolled hypertension (systolic blood pressure $>165 \mathrm{mmHg}$ or diastolic blood pressure $>95 \mathrm{mmHg}$ ) , history of severe recurrent depression, severe psychiatric disturbance, alcohol abuse or drug abuse, concurrent use of medication containing oestrogen, progestin, SERM, St. John's Wort, biphosphonates or dietary phyto-oestrogens, history of migraine associated with hormone use, smoker, vegan diet, participation in another clinical trial within 30

Black cohosh (Cimicifuga spp.) for menopausal symptoms (Review) 
days of enrolment,

Diagnostic criteria: not stated

Co-morbidities: not stated

Co-medications: not stated

\section{Interventions}

Number of study centres: 2

Country/location: Chicago, Illinois, US

Setting: University of Illinois Medical Centre outpatient facility, and University Feinberg School of Medicine

Intervention (route, total, dose/day, frequency): oral ethanolic extract of Cimicifuga racemosa below-ground parts (64 mg, standardised to $5.68 \%$ triterpene glycosides) 2 capsules daily; oral ethanolic extract of Trifolium pratense above-ground parts (189 mg) 2 capsules daily

Control (route, total, dose/day, frequency): oral CEO $(0.625 \mathrm{mg}) 1$ capsule daily and oral MDP $(2.5 \mathrm{mg}) 1$ capsule daily; oral placebo (not described) 2 capsules daily

Duration of intervention: 12 months (52 weeks)

Duration of follow-up: not applicable

Run-in period: not applicable

Treatment before study: 1 -month washout period for women using transdermal hormone preparations or oral botanical supplements, and 2-month washout period for women using oral $\mathrm{HT}$

Titration period: not applicable tigue), mood changes (e.g. depression, anxiety), sexual dysfunction (e.g. vaginal dryness, dyspareunia, libido, difficulty achieving orgasm), HRQoL, KI, GCS, Pittsburgh Sleep Quality Index, Positive and Negative Affect Schedule

Additional outcomes: complete blood count, urinalysis, serum chemistry, lipid analysis, serum oestradiol, serum FSH, serum LH, serum oestrone, serum testosterone, serum thyroid-stimulating hormone, serum sex hormone binding globulin, liver function test, prothrombin time, body weight, height, bone density, adverse events request

\section{Risk of bias}

Bias Authors' judgement

Support for judgement

Random sequence generation (selection Low risk bias)

Quote: "a random, computer- generated code assigned two women in each cluster to each of the four treatment arms. There were 11 clusters with eight women in each cluster"

Comment: probably done 
Geller 2009 (Continued)

\begin{tabular}{|c|c|c|}
\hline Allocation concealment (selection bias) & Unclear risk & $\begin{array}{l}\text { Method of allocation concealment not de- } \\
\text { scribed } \\
\text { Comment: probably not done }\end{array}$ \\
\hline $\begin{array}{l}\text { Blinding (performance bias and detection } \\
\text { bias) } \\
\text { All outcomes }\end{array}$ & Low risk & $\begin{array}{l}\text { Quote: "Double blinded"; "the study cap- } \\
\text { sules were identical in appearance, and } \\
\text { there was no detectable odor for any of the } \\
\text { preparations" } \\
\text { Comment: probably done }\end{array}$ \\
\hline $\begin{array}{l}\text { Incomplete outcome data (attrition bias) } \\
\text { All outcomes }\end{array}$ & High risk & $\begin{array}{l}\text { "intention-to-treat" was quoted, but the } \\
\text { analysis consisted only of "randomised } \\
\text { women who had been in the study for at } \\
\text { least } 3 \text { month" } \\
9 \text { women withdrew from the study - the } \\
\text { number and reasons for withdrawal dif- } \\
\text { fered between groups }\end{array}$ \\
\hline Selective reporting (reporting bias) & Unclear risk & $\begin{array}{l}\text { All primary and secondary outcomes listed } \\
\text { were reported, although no study protocol } \\
\text { was published or lodged }\end{array}$ \\
\hline Other bias & Unclear risk & $\begin{array}{l}\text { Baseline differences in race and BMI were } \\
\text { evident, although all analyses controlled for } \\
\text { these variables }\end{array}$ \\
\hline
\end{tabular}

Jacobson 2001

Methods

Design: randomised, double-blind, placebo-controlled, parallel group trial

Randomisation ratio: not stated

Study duration: not stated

Participants

Participant characteristics: 85 women enrolled, 85 were randomised (black cohosh $=42$, placebo $=43)$ and $16(18.8 \%)$ dropped out. Mean age (black cohosh $=52 \%$ were aged between 50 to 59 years, placebo $=51 \%$ were aged between 50 to 59 years). Duration of menopause not stated

Inclusion criteria: female, aged $>18$ years, previously treated for breast cancer at the Columbia-Presbyterian Medical Centre or 1 of its affiliates, experienced hot flushes daily, had completed primary therapy (including chemotherapy and radiotherapy) for breast cancer at least 2 months prior to study enrolment

Exclusion criteria: using hormone replacement therapy for hot flushes, pregnant, history of major psychiatric illness, known to have recurrent or metastatic breast cancer

Diagnostic criteria: not stated

Co-morbidities: history of breast cancer

Co-medications: tamoxifen

Black cohosh (Cimicifuga spp.) for menopausal symptoms (Review) 


\begin{tabular}{ll} 
Interventions & Number of study centres: not stated \\
Country/location: New York, New York, US \\
Setting: not stated \\
Intervention (route, total, dose/day, frequency): oral isopropanolic extract of Cimicifuga \\
racemosa (Remifemin, $10 \mathrm{mg}$ ) 2 capsules daily with meals \\
Control (route, total, dose/day, frequency): oral placebo (not described) 2 capsules daily \\
with meals \\
Duration of intervention: 60 days ( 8.6 weeks) \\
Duration of follow-up: not applicable \\
Run-in period: not applicable \\
Treatment before study: not stated \\
Titration period: not applicable \\
\hline Primary outcomes: hot flushes (number and intensity) \\
Secondary outcomes: menopausal symptom index, global rating of health and well-being \\
Additional outcomes: serum FSH, serum LH \\
\hline
\end{tabular}

Notes

This study reported final value scores. Data had to be extrapolated from figures to be suitable for the pooling of results

\section{Risk of bias}

\section{Bias}

Random sequence generation (selection Low risk bias)

\section{Support for judgement}

Quote: "We used one randomization list developed using the RanCode Plus program...Study participants [had] 50\% probability of assignment to either group"

Comment: probably done

Method of allocation concealment not described

Comment: probably not done

Blinding (performance bias and detection Unclear risk bias)

All outcomes

Unclear risk

Quote: “double-masked”, though there was no mention of who was blinded, or any assurance that interventions matched in appearance, taste or odour

Comment: probably done

Incomplete outcome data (attrition bias) Low risk All outcomes
"Intention-to-treat"; "missing data were handled by including all available data in the primary analyses"

Number and reasons for withdrawal were similar between groups 
Jacobson 2001 (Continued)

Selective reporting (reporting bias) Unclear risk

All primary and secondary outcomes listed were reported, although no study protocol was published or lodged

Other bias $\quad$ Unclear risk

Baseline differences in age, race, years of education, employment status and marital status were observed

Kronenberg 2009

Methods

Design: randomised, double-blind, placebo-controlled, parallel group trial

Randomisation ratio: not stated

Study duration: 4 years (from May 2001 to May 2005)

Participants

Participant characteristics: 74 were randomised (black cohosh $=37$, placebo $=37$ ) and 9

$(12.2 \%)$ dropped out. Mean age (black cohosh $=55.12 \pm 4.08$ years, placebo $=54.18 \pm$

3.58 years). Duration of menopause not stated

Inclusion criteria: female, postmenopausal, aged between 45 and 70 years, resident of

New York Metro area, BMI $<33 \mathrm{~kg} / \mathrm{m}^{2}$, amenorrhoea $\geq 12$ months, serum oestradiol $<30 \mathrm{pg} / \mathrm{mL}, \geq 5$ hot flushes per day

Exclusion criteria: hormone replacement therapy within the past 60 days, abnormal mammogram or transvaginal ultrasound

Diagnostic criteria: not stated

Co-morbidities: not stated

Co-medications: women were advised to stop taking phyto-oestrogen-containing supplements (such as soy isoflavones genestein or daidzein) or any herb, dietary supplement or over-the-counter product targeted at menopausal women (such as evening primrose, Rejuvex, Promensil, progesterone creams, etc.) and to not take any nutritional supplements other than multivitamins (not megadoses) throughout the study

Interventions

Number of study centres: 1

Country/location: New York, US

Setting: Columbia University College of Physicians and Surgeons Center for Menopause, Hormonal Disorders and Women's Health

Intervention (route, total, dose/day, frequency): oral ethanolic extract of Cimicifuga racemosa rhizome (CimiPure, $40 \mathrm{mg}$, standardised to $2.5 \%$ triterpene glycosides) 1 capsule, twice daily

Control (route, total, dose/day, frequency): oral placebo (dosage and formulation not described)

Duration of intervention: 12 months (52 weeks)

Duration of follow-up: not stated

Run-in period: not stated

Treatment before study: not stated

Titration period: not stated

Outcomes

Primary outcomes: hot flushes (intensity and frequency)

Secondary outcomes: menopausal symptoms (GCS), quality of life, serum oestradiol, serum oestrone, serum LH, serum FSH, bone density

Black cohosh (Cimicifuga spp.) for menopausal symptoms (Review)

Copyright ( 2012 The Cochrane Collaboration. Published by John Wiley \& Sons, Ltd. 
Additional outcomes: physical/gynaecological examination, Papanicolaou smear, blood chemistry, coagulation profile, liver function test, vaginal maturation index, mammogram, electrocardiogram, endometrial thickness

\begin{tabular}{l|l} 
Notes & This study reported final value scores
\end{tabular}

\section{Risk of bias}

\begin{tabular}{|c|c|c|}
\hline Bias & Authors' judgement & Support for judgement \\
\hline $\begin{array}{l}\text { Random sequence generation (selection } \\
\text { bias) }\end{array}$ & Unclear risk & $\begin{array}{l}\text { Quote: "randomised" (method not de- } \\
\text { scribed) } \\
\text { Comment: probably done }\end{array}$ \\
\hline Allocation concealment (selection bias) & Unclear risk & $\begin{array}{l}\text { Method of allocation concealment not de- } \\
\text { scribed } \\
\text { Comment: probably not done }\end{array}$ \\
\hline $\begin{array}{l}\text { Blinding (performance bias and detection } \\
\text { bias) } \\
\text { All outcomes }\end{array}$ & Unclear risk & $\begin{array}{l}\text { Quote: "double-blind"; though there was } \\
\text { no mention of who was blinded, or any as- } \\
\text { surance that interventions matched in ap- } \\
\text { pearance, taste or odour } \\
\text { Comment: probably done }\end{array}$ \\
\hline $\begin{array}{l}\text { Incomplete outcome data (attrition bias) } \\
\text { All outcomes }\end{array}$ & Low risk & $\begin{array}{l}\text { "All [women] were included in the Inten- } \\
\text { tion-to-treat analysis" } \\
9 \text { women withdrew from the study; how- } \\
\text { ever, the number and reasons for with- } \\
\text { drawal were not given for each group sep- } \\
\text { arately }\end{array}$ \\
\hline Selective reporting (reporting bias) & High risk & $\begin{array}{l}\text { No study protocol was published or lodged. } \\
\text { Data were reported for the primary out- } \\
\text { comes, but not for all secondary outcomes }\end{array}$ \\
\hline Other bias & Low risk & $\begin{array}{l}\text { There were no significant differences in } \\
\text { participant characteristics between groups } \\
\text { at baseline }\end{array}$ \\
\hline
\end{tabular}

Lehmann-Willenbrock 1988

\begin{tabular}{ll} 
Methods & $\begin{array}{l}\text { Design: randomised, controlled, single-centre trial } \\
\text { Randomisation ratio: not stated } \\
\text { Study duration: not stated }\end{array}$ \\
\hline Participants & $\begin{array}{l}\text { Participant characteristics: } 60 \text { women were randomised (oestriol }=15, \text { oestrogen }=15, \\
\text { oestradiol/norethisterone }=15, \text { black cohosh }=15) \text {, and } 5(8.3 \%) \text { dropped out. Mean } \\
\text { age not stated. Duration of menopause not stated }\end{array}$
\end{tabular}


Inclusion criteria: female, hysterectomised, aged under 40 years, has at least 1 intact ovary, complaining of climacteric symptoms

Exclusion criteria: type I diabetes mellitus, chronic hepatitis, deep vein thrombosis, breast cancer, contraindication to HT

Diagnostic criteria: not stated

Co-morbidities: not stated

Co-medications: not stated

Interventions

Number of study centres: 1

Country/location: Kiel, Germany

Setting: university gynaecological hospital

Intervention (route, total, dose/day, frequency): oral isopropanolic extract of Cimicifuga racemosa (Remifemin, $2 \mathrm{mg}$ ) 2 tablets, twice daily

Control (route, total, dose/day, frequency): oral oestriol (Ovestin, $1 \mathrm{mg}$ ) 1 tablet daily; oral conjugated oestrogen (Presomen, $1.25 \mathrm{mg}$ ) 1 tablet daily; oral oestradiol/norethisterone acetate (Trisequens) 1 tablet, daily

Duration of intervention: not stated

Duration of follow-up: 24 weeks

Run-in period: not stated

Treatment before study: not stated

Titration period: not applicable

Outcomes

Primary outcomes: KI, serum FSH, serum LH

Secondary outcomes: not stated

Additional outcomes: not stated

\begin{tabular}{l|l} 
Notes This study reported final value scores \\
\hline
\end{tabular}

\section{Risk of bias}

\section{Bias}

Random sequence generation (selection Unclear risk bias)

\begin{tabular}{|c|c|}
\hline Allocation concealment (selection bias) & Unclear risk \\
\hline $\begin{array}{l}\text { Blinding (performance bias and detection } \\
\text { bias) } \\
\text { All outcomes }\end{array}$ & Unclear risk \\
\hline
\end{tabular}

Incomplete outcome data (attrition bias) High risk All outcomes

\section{Support for judgement}

Quote: "randomised" (method not described)

Comment: probably done

Method of allocation concealment not described

Comment: probably not done

There is no mention of blinding

Comment: probably not done
ITT was not mentioned

5 women withdrew from the study; however, the number and reasons for withdrawal were not given for each group separately 


\section{Lehmann-Willenbrock 1988 (Continued)}

Selective reporting (reporting bias) Unclear risk

Other bias

Unclear risk
Data for all primary outcomes were reported, although no study protocol was published or lodged

Participant characteristics at baseline were not reported

\section{Nappi 2005}

Methods

Participants

\begin{tabular}{ll} 
Methods & D \\
\hline Participants & S \\
& P \\
& o \\
& o \\
& I
\end{tabular}

Design: randomised, controlled, multicentre, parallel group trial

Randomisation ratio: not stated

Study duration: not stated

Participant characteristics: 64 women enrolled, 64 were randomised (black cohosh $=32$, oestradiol $=32)$, and $1(1.6 \%)$ dropped out. Mean age (black cohosh $=50.5 \pm 2.1$ years, oestradiol $=50.9 \pm 1.8$ years). Duration of menopause (black cohosh $=9.0 \pm 2.9$ months, oestradiol $=9.1 \pm 3.0$ months)

Inclusion criteria: spontaneous menopause of at least 6 months' duration, FSH $>30$ $\mathrm{mIU} / \mathrm{L}$, presence of at least 5 hot flushes daily, endometrial thickness $<5 \mathrm{~mm}$

Exclusion criteria: previous HT, contraindications to HT

Diagnostic criteria: not stated

Co-morbidities: not stated

Co-medications: not stated

Interventions

Number of study centres: 2

Country/location: Modena and Pavia, Italy

Setting: university departments of obstetrics and gynaecology

Intervention (route, total, dose/day, frequency): oral isopropanolic extract of Cimicifuga racemosa (Remifemin, $40 \mathrm{mg}$ ) 1 tablet daily

Control (route, total, dose/day, frequency): transdermal oestradiol (Estraderm, $25 \mathrm{uG)}$ every 7 days, plus dihydrogesterone (Dufaston, $10 \mathrm{mg}$ ) 1 tablet daily for the last 12 days of the 3-month oestradiol treatment

Duration of intervention: 3 months (12 weeks)

Duration of follow-up: not applicable

Run-in period: not applicable

Treatment before study: not stated

Titration period: not applicable

Outcomes

Primary outcomes: hot flushes (number)

Secondary outcomes: vasomotor and urogenital symptoms (GCS), anxiety and depression (Symptom Rating Test)

Additional outcomes: endometrial thickness, serum FSH, serum LH, serum $17 \beta$-oestra-

diol, serum prolactin, serum cortisol, lipid profile, liver function test
This study reported final value scores

\section{Risk of bias}




\begin{tabular}{|c|c|c|}
\hline Bias & Authors' judgement & Support for judgement \\
\hline $\begin{array}{l}\text { Random sequence generation (selection } \\
\text { bias) }\end{array}$ & Low risk & $\begin{array}{l}\text { Quote: "patients were randomly allocated } \\
\text { on the basis of a computer-generated num- } \\
\text { ber list" } \\
\text { Comment: probably done }\end{array}$ \\
\hline Allocation concealment (selection bias) & Unclear risk & $\begin{array}{l}\text { Method of allocation concealment not de- } \\
\text { scribed } \\
\text { Comment: probably not done }\end{array}$ \\
\hline $\begin{array}{l}\text { Blinding (performance bias and detection } \\
\text { bias) } \\
\text { All outcomes }\end{array}$ & High risk & $\begin{array}{l}\text { Women were not blinded to treatment as } \\
\text { the } 2 \text { interventions used different routes } \\
\text { of administration and different dosage reg- } \\
\text { imens. It is not clear if observers were } \\
\text { blinded to treatment } \\
\text { Comment: probably not done }\end{array}$ \\
\hline $\begin{array}{l}\text { Incomplete outcome data (attrition bias) } \\
\text { All outcomes }\end{array}$ & High risk & $\begin{array}{l}\text { ITT was not mentioned } \\
1 \text { woman withdrew from the intervention } \\
\text { group owing to nausea. A similar number } \\
\text { of women in each group "refused to provide } \\
\text { a blood sample at follow-up" }\end{array}$ \\
\hline Selective reporting (reporting bias) & Unclear risk & $\begin{array}{l}\text { All primary and secondary outcomes listed } \\
\text { were reported, although no study protocol } \\
\text { was published or lodged }\end{array}$ \\
\hline Other bias & Low risk & $\begin{array}{l}\text { There were no significant differences in } \\
\text { participant characteristics between groups } \\
\text { at baseline }\end{array}$ \\
\hline
\end{tabular}

Newton 2006

Methods

Participants
Design: randomised, double-blind, placebo-controlled, multicentre, parallel group trial Randomisation ratio: not stated

Study duration: 25 months (from May 2001 to August 2003)

Participant characteristics: 351 women were randomised (black cohosh $=80$, multibotanical $=76$, multi-botanical plus dietary soy $=79, \mathrm{CEO}$ and $\mathrm{MPA}=32$, placebo $=$ $84)$, and $45(12.8 \%)$ dropped out. Mean age (black cohosh $=52.0 \pm 2.2$ years, multibotanical $=52.2 \pm 2.5$ years, multi-botanical plus dietary soy $=52.5 \pm 2.5$ years, CEO and $\mathrm{MPA}=52.3 \pm 2.6$ years, placebo $=52.0 \pm 2.5$ years $)$. Duration of menopause not stated

Inclusion criteria: female, late menopausal transition ( $\geq 1$ skipped menses in the last 12 months) or postmenopausal (no bleeding in the last 12 months) or FSH > 20 IU/ $\mathrm{mL}$ (if participant had undergone hysterectomy without bilateral oophorectomy), aged between 45 and 55 years, and $\geq 2$ vasomotor symptoms daily over the past 2 weeks (with 
$\geq 6$ moderate to severe symptoms), negative mammogram in the last 2 years, normal thyroid stimulating hormone level

Exclusion criteria: contraindications to HT, use of HT or oral contraceptives within the last 3 months, use of herbal medicines for menopausal symptoms within the last month, allergy to soy, bilateral oophorectomy, history of breast cancer, non-adherence $(<80 \%$ of capsules administered) during the run-in period

Diagnostic criteria: not stated

Co-morbidities: not stated

Co-medications: not stated

Interventions

Number of study centres: not stated

Country/location: Washington state, US

Setting: group health (an integrated health plan)

Intervention (route, total, dose/day, frequency): oral ethanolic extract of Cimicifuga racemosa rhizome and root (CimiPure, $80 \mathrm{mg}$, standardised to $2.5 \%$ triterpene glycosides) 2 capsules daily; oral multi-botanical (ProGyne, incorporating $50 \mathrm{mg}$ C. racemosa extract) 4 capsules daily; multi-botanical (ProGyne, incorporating $50 \mathrm{mg}$ C. racemosa extract) 4 capsules daily plus soy diet counselling; oral CEO $(0.625 \mathrm{mg}) 1$ tablet daily, with (for women with a uterus) or without (for women with a uterus) MDP (2.5 mg) 1 tablet daily

Control (route, total, dose/day, frequency): oral placebo (dose and constitution is not described)

Duration of intervention: 12 months (52 weeks)

Duration of follow-up: not applicable

Run-in period: 2 weeks

Treatment before study: not applicable

Titration period: not applicable

Outcomes

Primary outcomes: mean Wiklund Vasomotor Symptom subscale score, hot flushes and night sweats (frequency and intensity), vaginal bleeding

Secondary outcomes: daytime hot flush rate, night-time sweat rate, total Wiklund Menopause Symptom Scale Score, vaginal dryness, menstrual cyclicly, vaginal cytology, serum FSH, serum LH, serum oestradiol, serum sex hormone binding globulin Additional outcomes: adverse events

Notes

Newton 2006 and Reed 2008 report the same study, but different outcomes. This study reported change-from-baseline scores; final value scores were provided on request. Standard errors had to be converted to standard deviations to be suitable for the pooling of results

\section{Risk of bias}

Bias

Random sequence generation (selection Low risk bias)

Authors' judgement bias)

\section{Support for judgement}

Quote: "participants were randomly assigned by using SAS software, stratified by previous HT and hysterectomy; block sizes within strata ranged from 5 to 25 "

Comment: probably done 
Newton 2006 (Continued)

\begin{tabular}{|c|c|c|}
\hline Allocation concealment (selection bias) & Low risk & $\begin{array}{l}\text { Quote: "the study nurse determined the } \\
\text { appropriate stratum, assigned the partici- } \\
\text { pant the next study number in that stratum } \\
\text { without knowledge of group assignment, } \\
\text { and distributed study medications" } \\
\text { Comment: probably done }\end{array}$ \\
\hline $\begin{array}{l}\text { Blinding (performance bias and detection } \\
\text { bias) } \\
\text { All outcomes }\end{array}$ & Low risk & $\begin{array}{l}\text { Quote: "double-blind"; "to facilitate blind- } \\
\text { ing, medications and lactose placebo were } \\
\text { encapsulated to provide } 2 \text { white and } 2 \text { blue } \\
\text { capsules to each woman" } \\
\text { Comment: probably done }\end{array}$ \\
\hline $\begin{array}{l}\text { Incomplete outcome data (attrition bias) } \\
\text { All outcomes }\end{array}$ & Low risk & $\begin{array}{l}\text { "mixed-model analysis allowed us to use a } \\
\text { true intention-to-treat approach" } \\
\text { Numbers of withdrawals were similar be- } \\
\text { tween groups, though reasons for with- } \\
\text { drawal differed. } 16 \text { women were un- } \\
\text { blinded; however, numbers were not given } \\
\text { for each group separately }\end{array}$ \\
\hline Selective reporting (reporting bias) & Unclear risk & $\begin{array}{l}\text { All primary and secondary outcomes listed } \\
\text { were reported, although no study protocol } \\
\text { was published or lodged }\end{array}$ \\
\hline Other bias & Unclear risk & Baseline differences in BMI were observed \\
\hline
\end{tabular}

Oktem 2007

\begin{tabular}{|c|c|}
\hline Methods & $\begin{array}{l}\text { Design: randomised, controlled, single centre, parallel group trial } \\
\text { Randomisation ratio: not stated } \\
\text { Study duration: not stated }\end{array}$ \\
\hline Participants & $\begin{array}{l}\text { Participant characteristics: } 120 \text { women were randomised (black cohosh }=60 \text {, fluoxetine = } \\
60) \text { and } 40(33.3 \%) \text { dropped out. Mean age (black cohosh }=53.1 \pm 5.6 \text { years, fluoxetine } \\
=52.7 \pm 6.4 \text { years). Duration of menopause not stated } \\
\text { Inclusion criteria: female, amenorrhoea for at least } 1 \text { year and serum FSH }>40 \text { mIU/ } \\
\mathrm{mL} \text {, had sought relief of menopausal symptoms } \\
\text { Exclusion criteria: HT, herbal products or health food in the last } 3 \text { months, mental } \\
\text { illness, psychiatric drug use, malignant disease, uncontrolled thyroid disease } \\
\text { Diagnostic criteria: not stated } \\
\text { Co-morbidities: not stated } \\
\text { Co-medications: not stated }\end{array}$ \\
\hline Interventions & $\begin{array}{l}\text { Number of study centres: } 1 \\
\text { Country/location: Ankara, Turkey } \\
\text { Setting: university menopause clinic } \\
\text { Intervention (route, total, dose/day, frequency): oral black cohosh extract (Remixin, } 40\end{array}$ \\
\hline
\end{tabular}

Black cohosh (Cimicifuga spp.) for menopausal symptoms (Review)

Copyright ( 2012 The Cochrane Collaboration. Published by John Wiley \& Sons, Ltd. 
Oktem 2007 (Continued)

\begin{tabular}{|c|c|c|}
\hline & \multicolumn{2}{|c|}{$\begin{array}{l}\text { mg) } 1 \text { tablet daily } \\
\text { Control (route, total, dose/day, frequency): oral fluoxetine (Prozac HCl, } 20 \mathrm{mg}) 1 \text { tablet } \\
\text { daily } \\
\text { Duration of intervention: } 6 \text { months ( } 24 \text { weeks) } \\
\text { Duration of follow-up: not applicable } \\
\text { Run-in period: not applicable } \\
\text { Treatment before study: not stated } \\
\text { Titration period: not applicable }\end{array}$} \\
\hline Outcomes & \multicolumn{2}{|c|}{$\begin{array}{l}\text { Primary outcomes: monthly hot flush and night sweat score, modified KI } \\
\text { Secondary outcomes: Beck's Depression Scale Score, RAND-36 quality of life score } \\
\text { Additional outcomes: adverse effects }\end{array}$} \\
\hline Notes & \multicolumn{2}{|c|}{ This study reported final value scores } \\
\hline \multicolumn{3}{|l|}{ Risk of bias } \\
\hline Bias & Authors' judgement & Support for judgement \\
\hline $\begin{array}{l}\text { Random sequence generation (selection } \\
\text { bias) }\end{array}$ & Unclear risk & $\begin{array}{l}\text { Quote: "The study population...was ran- } \\
\text { domly assigned to } 2 \text { groups" } \\
\text { Comment: probably done }\end{array}$ \\
\hline Allocation concealment (selection bias) & Unclear risk & $\begin{array}{l}\text { Method of allocation concealment not de- } \\
\text { scribed } \\
\text { Comment: probably not done }\end{array}$ \\
\hline $\begin{array}{l}\text { Blinding (performance bias and detection } \\
\text { bias) } \\
\text { All outcomes }\end{array}$ & Unclear risk & $\begin{array}{l}\text { There is no mention of blinding } \\
\text { Comment: probably not done }\end{array}$ \\
\hline $\begin{array}{l}\text { Incomplete outcome data (attrition bias) } \\
\text { All outcomes }\end{array}$ & High risk & $\begin{array}{l}\text { ITT was not mentioned } \\
\text { Number of withdrawals were similar be- } \\
\text { tween groups, though reasons for with- } \\
\text { drawals were not provided }\end{array}$ \\
\hline Selective reporting (reporting bias) & Unclear risk & $\begin{array}{l}\text { All primary and secondary outcomes listed } \\
\text { were reported, although no study protocol } \\
\text { was published or lodged }\end{array}$ \\
\hline Other bias & Low risk & $\begin{array}{l}\text { There were no significant differences in } \\
\text { participant characteristics between groups } \\
\text { at baseline }\end{array}$ \\
\hline
\end{tabular}

Black cohosh (Cimicifuga spp.) for menopausal symptoms (Review) 
Methods

Participants
Design: randomised, placebo-controlled, double-blind, multicentre, parallel group trial Randomisation ratio: 1:1

Study duration: not stated

\begin{tabular}{|c|c|}
\hline & $\begin{array}{l}\text { 153, placebo }=151) \text {, and } 36 \text { dropped out }(11.8 \%) \text {. Mean age (black cohosh }=54.0 \pm 6 \text {. } \\
0 \text { years, placebo }=55.0 \pm 6.0 \text { years). Median duration of climacteric complaints (black } \\
\text { cohosh }=4.4 \text { years, placebo }=5.1 \text { years) } \\
\text { Inclusion criteria: female, postmenopausal }(\geq 12 \text { months since last regular menstruation } \\
\text { or } \geq 6 \text { months since last regular menstruation plus } \mathrm{FSH} \geq 50 \mathrm{U} / \mathrm{L}), \geq 45 \text { years of age, } \\
\text { MRS } \geq 0.4 \text { in at least } 3 \text { items } \\
\text { Exclusion criteria: BMI }>35 \mathrm{~kg} / \mathrm{m}^{2} \text {, cancer, drug abuse, diseases interfering with the } \\
\text { assessment of climacteric symptoms, participation in another clinical trial within the last } \\
180 \text { days } \\
\text { Diagnostic criteria: not stated } \\
\text { Co-morbidities: not stated } \\
\text { Co-medications: not stated }\end{array}$ \\
\hline Interventions & $\begin{array}{l}\text { Number of study centres: } 24 \\
\text { Country/location: Germany } \\
\text { Setting: Gynaecological and gynaecologically experienced private practices } \\
\text { Intervention (route, total, dose/day, frequency): oral isopropanolic extract of Cimicifuga } \\
\text { racemosa (Remifemin, equivalent to } 2.5 \mathrm{mg} \text { extract or } 20 \mathrm{mg} \text { root stock) } 1 \text { tablet, twice } \\
\text { a day } \\
\text { Control (route, total, dose/day, frequency): oral placebo (excipients only) } 1 \text { tablet, twice } \\
\text { a day } \\
\text { Duration of intervention: } 12 \text { weeks } \\
\text { Duration of follow-up: not applicable } \\
\text { Run-in period: not applicable } \\
\text { Treatment before study: } 1 \text {-week washout period for those taking non-hormonal cli- } \\
\text { macteric drugs, supplements, antiepileptics, psycholeptics or psychoanaleptics. 4-week } \\
\text { washout period for those taking hormone replacement therapy } \\
\text { Titration period: not applicable }\end{array}$ \\
\hline
\end{tabular}

Outcomes

Primary outcomes: intensity of climacteric symptoms (MRS)

Secondary outcomes: MRS subscales (hot flushes, atrophy, psyche and soma)

Additional outcomes: adverse events, liver enzymes, BMI
This study reported change-from-baseline scores; final value scores were not made available on request

\section{Risk of bias}

\section{Bias}

Random sequence generation (selection Unclear risk bias)

\section{Support for judgement}

Quote: "each patient was randomly assigned to receive one blinded Remifemin tablet or matching placebo...medication was prenumbered using a 1:1 - randomiza- 


\begin{tabular}{|c|c|c|}
\hline Allocation concealment (selection bias) & Unclear risk & $\begin{array}{l}\text { Method of allocation concealment not de- } \\
\text { scribed } \\
\text { Comment: probably not done }\end{array}$ \\
\hline $\begin{array}{l}\text { Blinding (performance bias and detection } \\
\text { bias) } \\
\text { All outcomes }\end{array}$ & Unclear risk & $\begin{array}{l}\text { Quote: "double-blind", though there was } \\
\text { no mention of who was blinded, or any as- } \\
\text { surance that interventions matched in ap- } \\
\text { pearance, taste or odour } \\
\text { Comment: probably done }\end{array}$ \\
\hline $\begin{array}{l}\text { Incomplete outcome data (attrition bias) } \\
\text { All outcomes }\end{array}$ & Low risk & $\begin{array}{l}\text { "The primary efficacy analysis used the In- } \\
\text { tention-to-treat population" } \\
\text { Number and reasons for withdrawal were } \\
\text { similar between groups }\end{array}$ \\
\hline Selective reporting (reporting bias) & Unclear risk & $\begin{array}{l}\text { All primary and secondary outcomes listed } \\
\text { were reported, although no study protocol } \\
\text { was published or lodged }\end{array}$ \\
\hline Other bias & Low risk & $\begin{array}{l}\text { There were no significant differences in } \\
\text { participant characteristics between groups } \\
\text { at baseline }\end{array}$ \\
\hline
\end{tabular}

Pockaj 2006

Methods

Participants
Design: randomised, placebo-controlled, double-blind, multicentre, cross-over trial Randomisation ratio: not stated

Study duration: 4 months (from 31st October 2003 to 4th March 2004)

Participant characteristics: 132 women were enrolled, 131 were randomised (black cohosh $=66$, placebo $=65)$ and $32(24.4 \%)$ dropped out. Mean age (black cohosh $=56.0$ \pm 8.3 years, placebo $=56.7 \pm 8.9$ years $)$. Duration of menopause not stated

Inclusion criteria: female, history of breast cancer or a perceived increased risk of breast cancer or did not wish to take oestrogen owing to the increased risk of breast cancer, $\geq 14$ hot flushes per week for a period of at least 1 month for which therapeutic intervention was desired

Exclusion criteria: malignant disease, concomitant use of anti-neoplastic chemotherapy, androgens, oestrogens, oral herbal therapies, therapeutic herbal teas or tinctures, any prior use of black cohosh, use of antidepressants within the last 2 weeks (or planned use in the next 9 weeks), and current or planned use of other agents for treating hot flushes. Concomitant use of tamoxifen, raloxifene, aromatase inhibitors, vitamin E or soy were permitted if the participant had been on therapy for at least 1 month and were not anticipating a change in therapy/dosage during the study

Diagnostic criteria: not stated 
Pockaj 2006 (Continued)

Co-morbidities: history of breast cancer (black cohosh $=59 \%$, placebo $=69 \%$ )

Co-medications: tamoxifen (black cohosh $=40 \%$, placebo $=48 \%$ ), raloxifene (black cohosh $=2 \%$, placebo $=0 \%)$, aromatase inhibitor $($ black cohosh $=12 \%$, placebo $=10 \%)$ , not receiving HT (black cohosh $=40 \%$, placebo $=33 \%$ )

Number of study centres: not stated
Country/location: US
Setting: community clinics, hospitals and medical centres affiliated with the NCCTG
Intervention (route, total, dose/day, frequency): oral extract of Cimicifuga racemosa rhi-
zome $(20 \mathrm{mg}$, standardised to $5 \%$ triterpene glycosides) 1 tablet, twice a day
Control (route, total, dose/day, frequency): oral placebo (dosage and constitution not
described) 1 tablet, twice a day
Duration of intervention: 8 weeks (4 weeks' active treatment and 4 weeks' placebo
treatment)
Duration of follow-up: not applicable
Run-in period: 1 week
Treatment before study: 1 week run-in period consisting of no treatment
Titration period: not applicable

Outcomes

Primary outcomes: hot flushes (severity and frequency)

Secondary outcomes: GCS, quality of life, toxicity/adverse events

Additional outcomes: treatment preference

Notes

This study reported change-from-baseline scores; final value scores were provided on request

\section{Risk of bias}

Bias

Random sequence generation (selection Unclear risk bias)

\section{Authors' judgement}

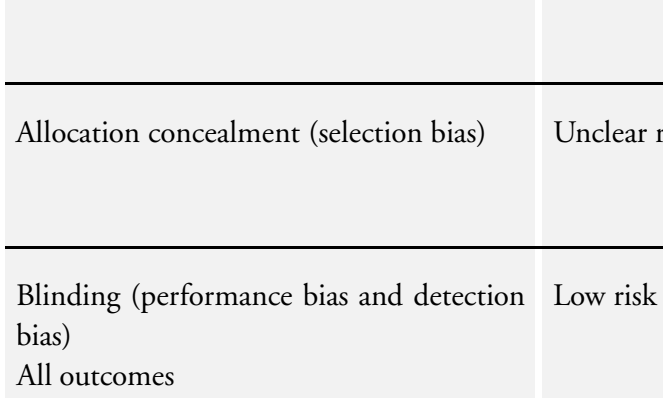

All outcomes

\section{Support for judgement}

Quote: "patients were randomly assigned" (method of sequence generation not described)

Comment: probably done

Method of allocation concealment not described

Comment: probably not done

Quote: "all treatments were doubleblinded"; "participants received...black cohosh or an identical appearing placebo" Comment: probably done

ITT was not mentioned.

16 women failed to provide hot flush data after baseline; however, the number and reasons for refusal were not given for each group separately 
Pockaj 2006 (Continued)

\begin{tabular}{l|l|l}
\hline Selective reporting (reporting bias) & High risk & $\begin{array}{l}\text { Excluding adverse events, data were re- } \\
\text { ported for most primary and secondary } \\
\text { outcomes, although no study protocol was } \\
\text { published or lodged }\end{array}$ \\
\hline Other bias & Low risk & $\begin{array}{l}\text { There were no significant differences in } \\
\text { participant characteristics between groups } \\
\text { at baseline }\end{array}$ \\
\hline
\end{tabular}

Stoll 1987

Methods

Design: randomised, double-blind, placebo-controlled trial

Randomisation ratio: not stated

Study duration: not stated

Participants

Participant characteristics: 80 women randomised (black cohosh $=30, \mathrm{CEO}=30$, placebo $=20)$ and $16(20 \%)$ dropped out. Mean age (black cohosh $=51.3 \pm 3.1$ years, $\mathrm{CEO}=$ $50.3 \pm 2.8$ years, placebo $=49.8 \pm 3.1$ years). Duration of menopause not stated

Inclusion criteria: female, aged 46 to 58 years, $\geq 3$ hot flushes a day, $\geq 1$ other climacteric symptom

Exclusion criteria: contraindications to HT, use of antihypertensive drugs, use of exogenous sexual hormones in the last 4 weeks, metabolic menopausal syndrome in the form of osteoporosis, menopause secondary to ovariectomy or radiation castration

Diagnostic criteria: not stated

Co-morbidities: hysterectomy, uterine or vaginal prolapse, mycosis, biliary troubles, hypotension and varicosis were reported in 33 women (black cohosh $=11, \mathrm{CEO}=13$, placebo $=9$ )

Co-medications: not stated

Interventions

Number of study centres: not stated

Country/location: not stated, possibly Germany

Setting: not stated

Intervention (route, total, dose/day, frequency): oral isopropanolic extract of Cimicifuga racemosa (Remifemin, $2 \mathrm{mg}) 2$ tablets twice a day; oral CEO $(0.625 \mathrm{mg}$, plus 3 oral placebo tablets) daily for 21 days, then oral placebo (not described) 2 tablets, twice a day Control (route, total, dose/day, frequency): oral placebo (not described) 2 tablets, twice a day

Duration of intervention: 12 weeks

Duration of follow-up: not applicable

Run-in period: not applicable

Treatment before study: not stated

Titration period: not applicable

Outcomes

Primary outcomes: KI

Secondary outcomes: Hamilton Anxiety Scale, vaginal epithelial proliferation, hot flushes, pruritus vulvae, genital inflammation, cohabitation/sexual complaints

Additional outcomes: not stated

Black cohosh (Cimicifuga spp.) for menopausal symptoms (Review) 


\begin{tabular}{|c|c|c|}
\hline Notes & \multicolumn{2}{|c|}{$\begin{array}{l}\text { Article in German. This study reported final value scores. Data had to be extrapolated } \\
\text { from figures to be suitable for the pooling of results }\end{array}$} \\
\hline \multicolumn{3}{|l|}{ Risk of bias } \\
\hline Bias & Authors' judgement & Support for judgement \\
\hline $\begin{array}{l}\text { Random sequence generation (selection } \\
\text { bias) }\end{array}$ & Unclear risk & $\begin{array}{l}\text { Quote: "randomised" (method not de- } \\
\text { scribed) } \\
\text { Comment: probably done }\end{array}$ \\
\hline Allocation concealment (selection bias) & Unclear risk & $\begin{array}{l}\text { Method of allocation concealment not de- } \\
\text { scribed } \\
\text { Comment: probably not don }\end{array}$ \\
\hline $\begin{array}{l}\text { Blinding (performance bias and detection } \\
\text { bias) } \\
\text { All outcomes }\end{array}$ & Low risk & $\begin{array}{l}\text { Quote: "double blind"; interventions were } \\
\text { identical in taste and appearance (trans- } \\
\text { lated) } \\
\text { Comment: probably done }\end{array}$ \\
\hline $\begin{array}{l}\text { Incomplete outcome data (attrition bias) } \\
\text { All outcomes }\end{array}$ & High risk & $\begin{array}{l}\text { ITT was not mentioned } \\
\text { The number and reasons for withdrawal } \\
\text { differed between groups }\end{array}$ \\
\hline Selective reporting (reporting bias) & Unclear risk & $\begin{array}{l}\text { All primary and secondary outcomes listed } \\
\text { were reported, although no study protocol } \\
\text { was published or lodged }\end{array}$ \\
\hline Other bias & Unclear risk & $\begin{array}{l}\text { Baseline differences in mean parturition } \\
\text { rate were observed }\end{array}$ \\
\hline
\end{tabular}

Wuttke 2003

Methods
Design: randomised, double-blind, placebo-controlled, multicentre, parallel group trial Randomisation ratio: not stated

Study duration: 23 months (from November 1998 to September 2000)

Participants

Participant characteristics: 97 women were randomised, 2 (2.1\%) dropped out and 33 $(34 \%)$ violated the study protocol. This left 62 women for analysis (black cohosh $=20$, $\mathrm{CEO}=22$, placebo $=20)$. Mean age (black cohosh $=52.25 \pm 3.19, \mathrm{CEO}=52.32 \pm 3$. 03 , placebo $=54.05 \pm 4.36$ ). Mean duration of menopause not stated Inclusion criteria: female, postmenopausal, aged 40 to 60 years, $\mathrm{BMI} \leq 30 \mathrm{~kg} / \mathrm{m}^{2}$, last menstrual bleed $\geq 6$ months ago, $17 \beta$-oestradiol $\leq 40 \mathrm{pg} / \mathrm{mL}$ and $\mathrm{FSH} \geq 25 \mathrm{mIU} / \mathrm{mL}$, $\geq 3$ hot flushes a day during the run-in period, MRS (MRS, sum of items 1 to 6 ) $\geq 1$. 7 at visits 1 and 2 , MRS item $1 \geq 0.3$ at visits 1 and 2

Exclusion criteria: signs of ovulatory or anovulatory cycles during the run-in period, hysterectomy, non-response to pretreatment with oestrogens, contraindications to HT, 
unresolved genital bleeding, suspicion or existence of an oestrogen-dependent breast or endometrial carcinoma, endometrial thickness $>5 \mathrm{~mm}$, endometriosis, past or present thromboembolism, phlebitis, acute or chronic hepatic lesion, metabolic disorders of bile pigments, diabetes mellitus, sickle cell anaemia, clinically relevant hypertriglyceridaemia or hypercholesterolaemia, history of myocardial infarction, genital neoplasms, known sensitivity to investigational drugs or ingredients, concomitant treatment with oestrogenic substances, psychotropics, antidepressants, hypnotics or sedatives, alcohol or drug abuse, poor general condition

Diagnostic criteria: not stated

Co-morbidities: not stated

Co-medications: not stated

\section{Interventions}

Number of study centres: 13

Country/location: Czech Republic

Setting: private gynaecological practices and outpatient clinics

Intervention (route, total, dose/day, frequency): oral dried/ethanolic extract of Cimicifuga racemosa rhizome (Klimadynon or Menofem, $20 \mathrm{mg}$ ) 2 capsules daily; oral CEO (Oestrofeminal, $0.3 \mathrm{mg}$ ) 2 capsules daily

Control (route, total, dose/day, frequency): oral placebo (constitution not described) 2 capsules daily

Duration of intervention: 12 weeks

Duration of follow-up: not applicable

Run-in period: 2 weeks

Treatment before study: not stated

Titration period: not applicable

Primary outcomes: CrossLaps (bone degradation marker), bone-specific ALP (bone formation marker), LH, FSH, sex hormone binding globulin, total cholesterol, high-density lipoprotein cholesterol, low-density lipoprotein cholesterol, triglycerides, $17 \beta$-oestradiol, vaginal cytology, MRS

Secondary outcomes: hot flushes, vaginal bleeding, endometrial thickness, MRS subscores (major climacteric complaints, somatic complaints, mental score), sweating episodes, sleep disturbances

Additional outcomes: blood chemistry, liver function test, complete blood count, activated thromboplastin time, international normalised ratio, blood pressure, heart rate, body weight, adverse events

Notes

Intervention may be a combination formula, although this is not clear. This study reported change-from-baseline scores; final value scores were not provided on request. To extract data suitable for the pooling of results, standard errors had to be converted to standard deviations, some data extrapolated from figures, and postintervention means extrapolated from baseline and change from baseline data

\section{Risk of bias}


Wuttke 2003 (Continued)

\begin{tabular}{|c|c|c|}
\hline $\begin{array}{l}\text { Random sequence generation (selection } \\
\text { bias) }\end{array}$ & Unclear risk & $\begin{array}{l}\text { Quote: "patients were randomized to treat- } \\
\text { ments using a randomly permuted block } \\
\text { design" (method of sequence generation } \\
\text { not described) } \\
\text { Comment: probably done }\end{array}$ \\
\hline Allocation concealment (selection bias) & Unclear risk & $\begin{array}{l}\text { Method of allocation concealment not de- } \\
\text { scribed } \\
\text { Comment: probably not done }\end{array}$ \\
\hline $\begin{array}{l}\text { Blinding (performance bias and detection } \\
\text { bias) } \\
\text { All outcomes }\end{array}$ & Low risk & $\begin{array}{l}\text { Quote: "double-blind"; "All three prepara- } \\
\text { tions were identical in appearance" } \\
\text { Comment: probably done }\end{array}$ \\
\hline $\begin{array}{l}\text { Incomplete outcome data (attrition bias) } \\
\text { All outcomes }\end{array}$ & High risk & $\begin{array}{l}\text { "The remaining...women were included in } \\
\text { the per-protocol (PP) analysis" } \\
\text { Participant withdrawals were not reported }\end{array}$ \\
\hline Selective reporting (reporting bias) & High risk & $\begin{array}{l}\text { Data is reported for the primary outcome, } \\
\text { and for most secondary outcomes (exclud- } \\
\text { ing hot flushes, vaginal bleeding and sleep } \\
\text { disturbances). No study protocol was pub- } \\
\text { lished or lodged }\end{array}$ \\
\hline Other bias & Unclear risk & $\begin{array}{l}\text { Baseline differences in MRS scores and } \\
\text { oestradiol and FSH levels were observed }\end{array}$ \\
\hline
\end{tabular}

ALP: alkaline phosphatase; BMI: body mass index; CEO: conjugated equine oestrogen; CHD: coronary heart disease; DEXA, dualenergy X-ray absorptiometry; DSM-IV: Diagnostic and Statistical Manual of Mental Disorders, 4th Edition; FSH: follicle stimulation hormone; GCS: Greene Climacteric Scale; HRQoL: health-related quality of life; HT: hormone therapy; ITT: intention to treat; KI: Kupperman Index; LH: luteinising hormone; MDP: medroxyprogesterone; MRS: Menopause Rating Scale; NCCTG: North Central Cancer Treatment Group; SERM: selective oestrogen receptor modulator.

\section{Characteristics of excluded studies [ordered by study ID]}

\begin{tabular}{ll}
\hline Study & Reason for exclusion \\
\hline Blohmer 2007 & The active intervention was a combination formulation (black cohosh and St. John's Wort) \\
\hline Chung 2007 & The active intervention was a combination formulation (black cohosh and St. John's Wort) \\
\hline Liske 2002 & The trial was a dose comparison study; hence, the comparator group was inappropriate \\
\hline Myoung 2008 & The active intervention was a combination formulation (black cohosh and St. John's Wort) \\
\hline $\begin{array}{l}\text { Black cohosh (Cimicifuga spp.) for menopausal symptoms (Review) } \\
\text { Copyright } \odot 20 \text { 2 } 2 \text { The Cochrane Collaboration. Published by John Wiley \& Sons, Ltd. }\end{array}$
\end{tabular}


(Continued)

Park 2006 The active intervention was a combination formulation (black cohosh and St. John's Wort)

Rotem 2007 The active intervention was a combination formulation (black cohosh, dong quai, milk thistle, red clover, American ginseng and chaste-tree berry)

Sammartino 2006 The active intervention was a combination formulation (black cohosh, isoflavones and lignans)

Uebelhack 2006 The active intervention was a combination formulation (black cohosh and St. John's Wort)

Verhoeven 2005 The active intervention was a combination formulation (black cohosh and Soy isoflavones)

\section{Characteristics of studies awaiting assessment [ordered by study ID]}

Aly 2009

\begin{tabular}{|c|c|}
\hline Methods & $\begin{array}{l}\text { Design: randomised, placebo-controlled trial } \\
\text { Randomisation ratio: not stated } \\
\text { Study duration: not stated }\end{array}$ \\
\hline Participants & $\begin{array}{l}\text { Participant characteristics: } 80 \text { healthy symptomatic postmenopausal women } \\
\text { Inclusion criteria: female and postmenopausal } \\
\text { Exclusion criteria: not stated } \\
\text { Diagnostic criteria: not stated } \\
\text { Co-morbidities: not stated } \\
\text { Co-medications: not stated }\end{array}$ \\
\hline Interventions & $\begin{array}{l}\text { Number of study centres: } 1 \\
\text { Country/location: not stated } \\
\text { Setting: university affiliated tertiary centre } \\
\text { Intervention (route, total, dose/day, frequency): dried extract of Cimicifuga racemosa rhizome (Klimadynon), } 40 \mathrm{mg} \\
\text { daily } \\
\text { Control (route, total, dose/day, frequency): placebo (description and dosage not reported) } \\
\text { Duration of intervention: } 12 \text { months } \\
\text { Duration of follow-up: not stated } \\
\text { Run-in period: not stated } \\
\text { Treatment before study: not stated } \\
\text { Titration period: not stated }\end{array}$ \\
\hline Outcomes & $\begin{array}{l}\text { Primary outcomes: not stated } \\
\text { Secondary outcomes: not stated } \\
\text { Additional outcomes: MRS, endometrial thickness, breast changes }\end{array}$ \\
\hline Notes & Conference abstract only. Unable to locate author or full-text article \\
\hline
\end{tabular}

Black cohosh (Cimicifuga spp.) for menopausal symptoms (Review) 
Kim 2009

\begin{tabular}{|c|c|}
\hline Methods & $\begin{array}{l}\text { Design: randomised controlled trial } \\
\text { Randomisation ratio: not stated } \\
\text { Study duration: not stated }\end{array}$ \\
\hline Participants & $\begin{array}{l}\text { Participant characteristics: } 90 \text { postmenopausal women } \\
\text { Inclusion criteria: female and postmenopausal } \\
\text { Exclusion criteria: not stated } \\
\text { Diagnostic criteria: not stated } \\
\text { Co-morbidities: not stated } \\
\text { Co-medications: not stated }\end{array}$ \\
\hline Interventions & $\begin{array}{l}\text { Number of study centres: not stated } \\
\text { Country/location: not stated } \\
\text { Setting: not stated } \\
\text { Intervention (route, total, dose/day, frequency): black cohosh root extract (description and dosage not reported) } \\
\text { Control (route, total, dose/day, frequency): CEO } 0.625 \mathrm{mg} \text { (frequency not reported) } \\
\text { Duration of intervention: } 6 \text { months } \\
\text { Duration of follow-up: not stated } \\
\text { Run-in period: not stated } \\
\text { Treatment before study: not stated } \\
\text { Titration period: not stated }\end{array}$ \\
\hline Outcomes & $\begin{array}{l}\text { Primary outcomes: not stated } \\
\text { Secondary outcomes: not stated } \\
\text { Additional outcomes: KI, bone mineral density, urinary deoxypyridinolin }\end{array}$ \\
\hline Notes & Conference abstract only. Unable to locate author or full-text article \\
\hline
\end{tabular}

CEO: conjugated equine oestrogen; KI: Kupperman Index; MRS: Menopause Rating Scale.

\section{Characteristics of ongoing studies [ordered by study ID]}

Vichinsartvichai 2012

Trial name or title Black Cohosh Extract for the Management of Moderate to Severe Menopausal Symptoms in Thai Women

\begin{tabular}{ll}
\hline Methods & Randomised, double-blind, placebo-controlled trial with 2 parallel arms \\
\hline Participants & Thai women; perimenopausal or postmenopausal; $\geq 40$ years of age; Kupperman Index score $\geq 20$ \\
\hline Interventions & Cimicifuga racemosa rhizome and root extract or placebo, for 12 weeks \\
\hline
\end{tabular}

Outcomes Kupperman Index score, frequency of menopausal symptoms, adverse events, liver function, quality of life

Starting date December 2011

Black cohosh (Cimicifuga spp.) for menopausal symptoms (Review) 
Vichinsartvichai 2012 (Continued)

Contact information Dr Patsama Vichinsartvichai. Email: pat_si109@hotmail.com

Notes

Black cohosh (Cimicifuga spp.) for menopausal symptoms (Review) 
DATA AND ANALYSES

Comparison 1. Black cohosh versus placebo

\begin{tabular}{|c|c|c|c|c|}
\hline Outcome or subgroup title & $\begin{array}{l}\text { No. of } \\
\text { studies }\end{array}$ & $\begin{array}{c}\text { No. of } \\
\text { participants }\end{array}$ & Statistical method & Effect size \\
\hline $\begin{array}{l}1 \text { Vasomotor symptoms: daily hot } \\
\text { flush frequency }\end{array}$ & 3 & 393 & Mean Difference (IV, Fixed, 95\% CI) & $0.07[-0.43,0.56]$ \\
\hline $\begin{array}{l}2 \text { Vasomotor symptoms: weekly } \\
\text { hot flush frequency }\end{array}$ & 2 & & Mean Difference (IV, Fixed, 95\% CI) & Totals not selected \\
\hline $\begin{array}{l}3 \text { Vasomotor symptoms: hot flush } \\
\text { intensity }\end{array}$ & 3 & 214 & Mean Difference (IV, Fixed, 95\% CI) & $0.12[-0.06,0.30]$ \\
\hline $\begin{array}{l}4 \text { Vasomotor symptoms: night } \\
\text { sweats }\end{array}$ & 1 & 164 & Mean Difference (IV, Fixed, 95\% CI) & $0.27[-0.16,0.70]$ \\
\hline $\begin{array}{l}\text { 4.1 Night sweat frequency per } \\
\text { day }\end{array}$ & 1 & 164 & Mean Difference (IV, Fixed, 95\% CI) & $0.27[-0.16,0.70]$ \\
\hline 5 Menopausal Symptom Score & 4 & 357 & Std. Mean Difference (IV, Fixed, 95\% CI) & $-0.10[-0.32,0.11]$ \\
\hline 5.1 Kupperman Index & 2 & 165 & Std. Mean Difference (IV, Fixed, 95\% CI) & $-0.02[-0.34,0.30]$ \\
\hline 5.2 Greene Climacteric Scale & 1 & 28 & Std. Mean Difference (IV, Fixed, 95\% CI) & $0.43[-0.32,1.18]$ \\
\hline $\begin{array}{l}5.3 \text { Wiklund Menopause } \\
\text { Symptom Score }\end{array}$ & 1 & 164 & Std. Mean Difference (IV, Fixed, 95\% CI) & $-0.27[-0.58,0.04]$ \\
\hline 6 Adverse events & 2 & 344 & Risk Ratio (M-H, Fixed, 95\% CI) & $1.04[0.82,1.32]$ \\
\hline
\end{tabular}

Comparison 2. Black cohosh versus hormone therapy

\begin{tabular}{|c|c|c|c|c|}
\hline Outcome or subgroup title & $\begin{array}{l}\text { No. of } \\
\text { studies }\end{array}$ & $\begin{array}{c}\text { No. of } \\
\text { participants }\end{array}$ & Statistical method & Effect size \\
\hline $\begin{array}{l}1 \text { Vasomotor symptoms: daily hot } \\
\text { flush frequency }\end{array}$ & 2 & & Mean Difference (IV, Fixed, 95\% CI) & Totals not selected \\
\hline $\begin{array}{l}2 \text { Vasomotor symptoms: weekly } \\
\text { hot flush frequency }\end{array}$ & 1 & 44 & Mean Difference (IV, Fixed, 95\% CI) & $26.42[18.59,34.25]$ \\
\hline $\begin{array}{l}3 \text { Vasomotor symptoms: hot flush } \\
\text { intensity }\end{array}$ & 2 & & Mean Difference (IV, Fixed, 95\% CI) & Totals not selected \\
\hline $\begin{array}{l}4 \text { Vasomotor symptoms: night } \\
\text { sweats }\end{array}$ & 1 & 112 & Mean Difference (IV, Fixed, 95\% CI) & $0.93[0.47,1.39]$ \\
\hline $\begin{array}{l}\text { 4.1 Night sweat frequency per } \\
\text { day }\end{array}$ & 1 & 112 & Mean Difference (IV, Fixed, 95\% CI) & $0.93[0.47,1.39]$ \\
\hline 5 Menopausal Symptom Score & 5 & 468 & Std. Mean Difference (IV, Fixed, 95\% CI) & $0.32[0.13,0.51]$ \\
\hline 5.1 Kupperman Index & 3 & 312 & Std. Mean Difference (IV, Fixed, 95\% CI) & $0.20[-0.02,0.43]$ \\
\hline 5.2 Greene Climacteric Scale & 1 & 44 & Std. Mean Difference (IV, Fixed, 95\% CI) & $0.25[-0.37,0.87]$ \\
\hline $\begin{array}{l}5.3 \text { Wiklund Menopause } \\
\text { Symptom Score }\end{array}$ & 1 & 112 & Std. Mean Difference (IV, Fixed, 95\% CI) & $0.77[0.35,1.19]$ \\
\hline 6 Adverse events & 1 & 42 & Risk Ratio (M-H, Fixed, 95\% CI) & $0.83[0.21,3.24]$ \\
\hline
\end{tabular}


Comparison 3. Black cohosh versus red clover

\begin{tabular}{lcccc} 
Outcome or subgroup title & $\begin{array}{c}\text { No. of } \\
\text { studies }\end{array}$ & $\begin{array}{c}\text { No. of } \\
\text { participants }\end{array}$ & Statistical method & Effect size \\
\hline $\begin{array}{l}1 \text { Vasomotor symptoms: hot flush } \\
\text { frequency }\end{array}$ & 1 & 49 & Mean Difference (IV, Fixed, 95\% CI) & $9.38[-1.04,19.80]$ \\
$\begin{array}{l}\text { Vasomotor symptoms: hot flush } \\
\text { intensity }\end{array}$ & 1 & 50 & Mean Difference (IV, Fixed, 95\% CI) & $0.42[-0.08,0.92]$ \\
\begin{tabular}{l}
3 Menopausal score \\
\hline
\end{tabular} & 1 & 51 & Mean Difference (IV, Fixed, 95\% CI) & $-1.28[-5.48,2.92]$ \\
\hline
\end{tabular}

Comparison 4. Black cohosh versus fluoxetine

\begin{tabular}{lcccc} 
Outcome or subgroup title & $\begin{array}{c}\text { No. of } \\
\text { studies }\end{array}$ & $\begin{array}{c}\text { No. of } \\
\text { participants }\end{array}$ & Statistical method & Effect size \\
\hline $\begin{array}{l}\text { 1 Vasomotor symptoms: night } \\
\quad \text { sweats }\end{array}$ & 1 & 80 & Mean Difference (IV, Fixed, 95\% CI) & $-85.0[-132.50,-37$. \\
$\quad \begin{array}{l}\text { 1.1 Night sweat score per } \\
\quad \text { month }\end{array}$ & 1 & 80 & Mean Difference (IV, Fixed, 95\% CI) & $-85]$ \\
$\begin{array}{l}\text { Menopausal score } \\
\text { 2.1 Kupperman Index }\end{array}$ & 1 & 80 & Mean Difference (IV, Fixed, 95\% CI) & $50]$ \\
\hline
\end{tabular}

\section{Analysis I.I. Comparison I Black cohosh versus placebo, Outcome I Vasomotor symptoms: daily hot flush frequency.}

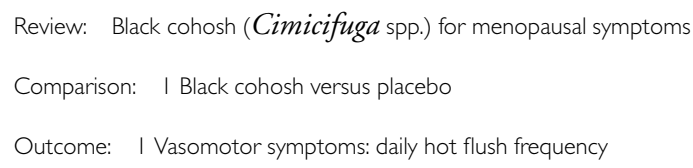

\begin{tabular}{|c|c|c|c|c|c|c|c|}
\hline \multirow[t]{2}{*}{ Study or subgroup } & \multirow{2}{*}{$\begin{array}{r}\text { Black cohosh } \\
\mathrm{N}\end{array}$} & \multicolumn{2}{|r|}{ Placebo } & \multicolumn{2}{|r|}{$\begin{array}{r}\text { Mean } \\
\text { Difference }\end{array}$} & \multirow[t]{2}{*}{ Weight } & \multirow{2}{*}{$\begin{array}{r}\text { Mean } \\
\text { Difference } \\
\text { IV,Fixed,95\% CI }\end{array}$} \\
\hline & & Mean(SD) & N & Mean(SD) & IV,Fixed,95\% Cl & & \\
\hline Frei-Kleiner 2005 & 81 & $1.66(1.69)$ & 41 & $1.85(1.62)$ & 7 & $64.4 \%$ & $-0.19[-0.81,0.43]$ \\
\hline Newton 2006 & 80 & 3.31 (3.36) & 84 & $3.21(3.41)$ & $\longrightarrow$ & $22.9 \%$ & $0.10[-0.94,1.14]$ \\
\hline Pockaj 2006 & 53 & $5.86(3.97)$ & 54 & $4.54(3.32)$ & 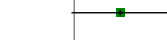 & $12.7 \%$ & $1.32[-0.07,2.7 \mid]$ \\
\hline Total $(95 \% \mathrm{CI})$ & 214 & & 179 & & 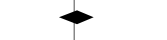 & $100.0 \%$ & $0.07[-0.43,0.56]$ \\
\hline \multicolumn{8}{|c|}{ Heterogeneity: Chi $^{2}=3.80, d f=2(P=0.15) ; 1^{2}=47 \%$} \\
\hline \multicolumn{8}{|c|}{ Test for overall effect: $Z=0.27(P=0.79)$} \\
\hline \multicolumn{8}{|c|}{ Test for subgroup differences: Not applicable } \\
\hline & & & & & 2 & 4 & \\
\hline \multicolumn{8}{|c|}{ Favours black cohosh Favours placebo } \\
\hline
\end{tabular}


Analysis I.2. Comparison I Black cohosh versus placebo, Outcome 2 Vasomotor symptoms: weekly hot flush frequency.

Review: Black cohosh (Cimicifuga spp.) for menopausal symptoms

Comparison: I Black cohosh versus placebo

Outcome: 2 Vasomotor symptoms: weekly hot flush frequency

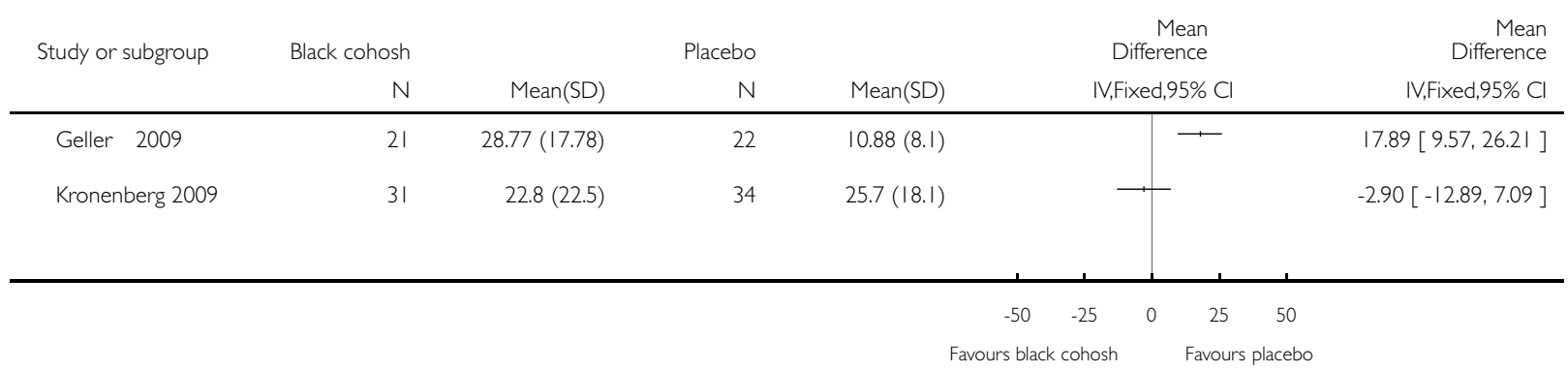




\section{Analysis I.3. Comparison I Black cohosh versus placebo, Outcome 3 Vasomotor symptoms: hot flush}

intensity.

Review: Black cohosh (Cimicifuga spp.) for menopausal symptoms

Comparison: I Black cohosh versus placebo

Outcome: 3 Vasomotor symptoms: hot flush intensity

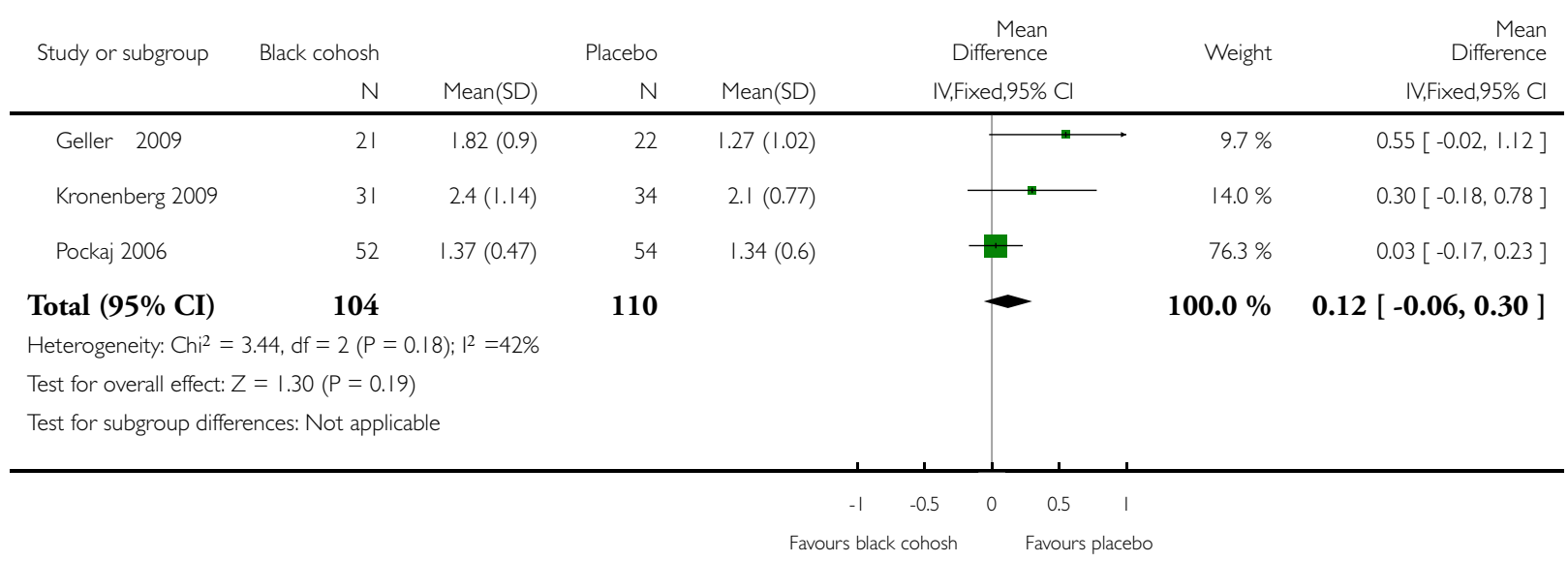

\section{Analysis I.4. Comparison I Black cohosh versus placebo, Outcome 4 Vasomotor symptoms: night sweats.}

Review: Black cohosh (Cimicifuga spp.) for menopausal symptoms

Comparison: | Black cohosh versus placebo

Outcome: 4 Vasomotor symptoms: night sweats

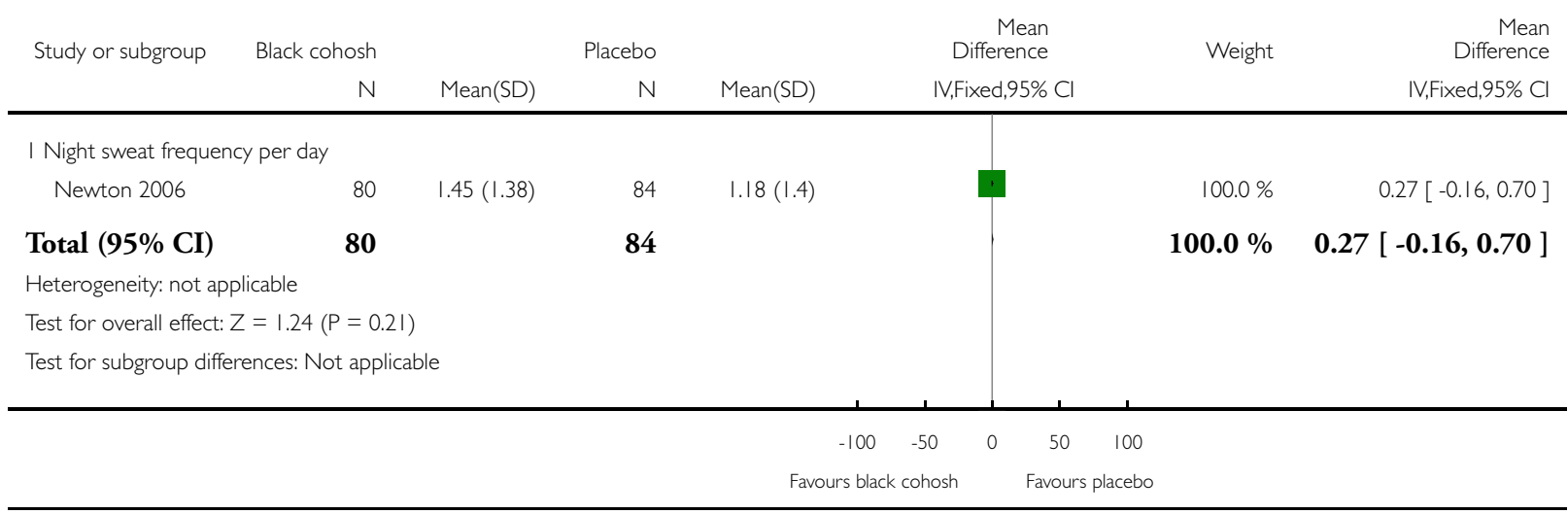

Black cohosh (Cimicifuga spp.) for menopausal symptoms (Review) 


\section{Analysis I.5. Comparison I Black cohosh versus placebo, Outcome 5 Menopausal Symptom Score.}

Review: Black cohosh (Cimicifuga spp.) for menopausal symptoms

Comparison: I Black cohosh versus placebo

Outcome: 5 Menopausal Symptom Score

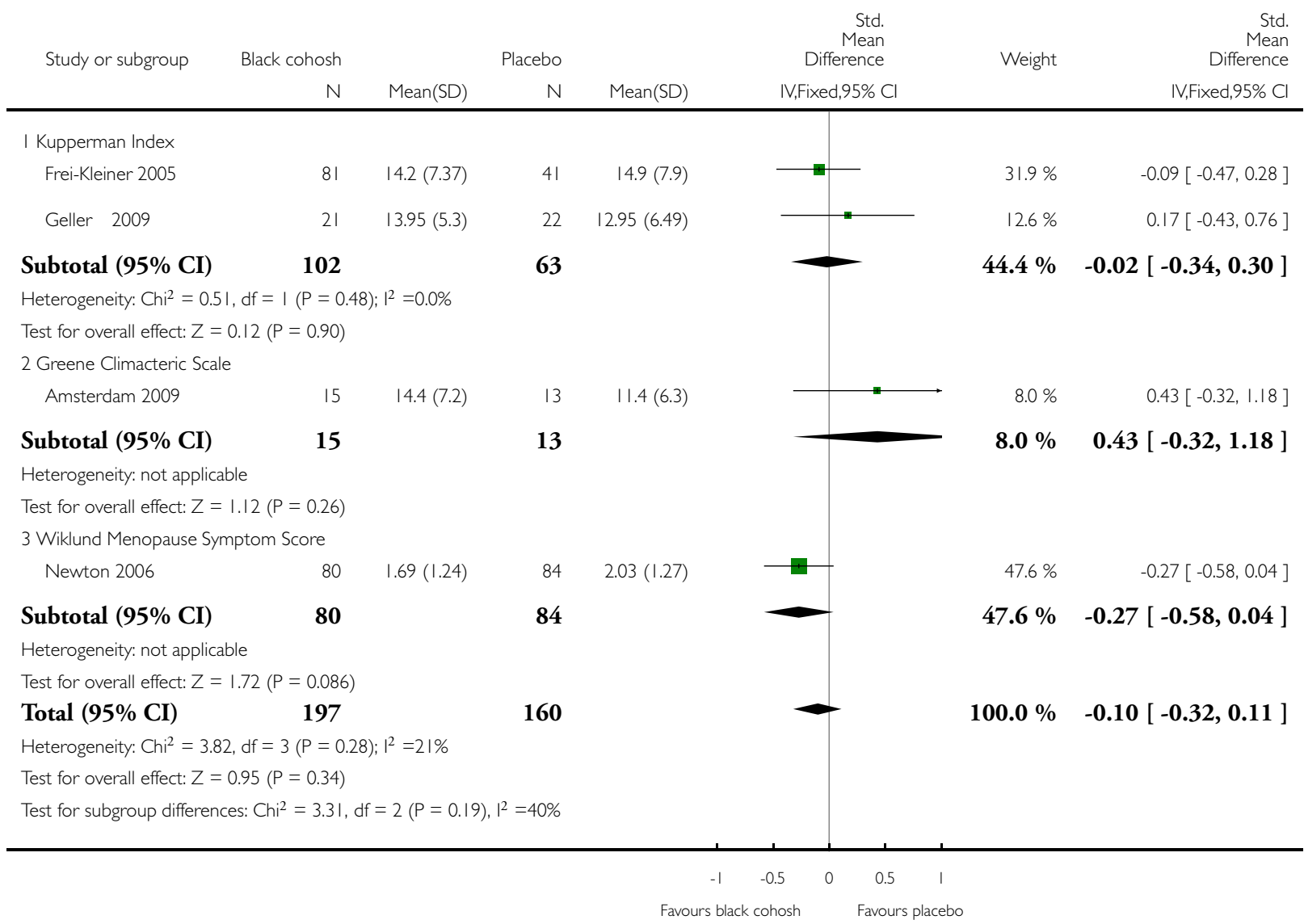

Black cohosh (Cimicifuga spp.) for menopausal symptoms (Review) 


\section{Analysis I.6. Comparison I Black cohosh versus placebo, Outcome 6 Adverse events.}

Review: Black cohosh (Cimicifuga spp.) for menopausal symptoms

Comparison: I Black cohosh versus placebo

Outcome: 6 Adverse events

\begin{tabular}{|c|c|c|c|c|c|}
\hline \multirow[t]{2}{*}{ Study or subgroup } & Black cohosh & Placebo & Risk Ratio & \multirow[t]{2}{*}{ Weight } & \multirow{2}{*}{$\begin{array}{r}\text { Risk Ratio } \\
\text { M-H,Fixed,95\% Cl }\end{array}$} \\
\hline & $n / N$ & $\mathrm{n} / \mathrm{N}$ & M-H,Fixed,95\% Cl & & \\
\hline Osmers 2005 & $71 / 153$ & $67 / 151$ & & $91.8 \%$ & $1.05[0.82,1.34]$ \\
\hline Wuttke 2003 & $6 / 20$ & $6 / 20$ & & $8.2 \%$ & $1.00[0.39,2.58]$ \\
\hline Total (95\% CI) & 173 & 171 & $\rightarrow$ & $100.0 \%$ & $1.04[0.82,1.32]$ \\
\hline \multicolumn{6}{|c|}{ Total events: 77 (Black cohosh), 73 (Placebo) } \\
\hline \multicolumn{6}{|c|}{ Heterogeneity: $\mathrm{Chi}^{2}=0.0 \mathrm{I}, \mathrm{df}=\mathrm{I}(\mathrm{P}=0.93) ; \mathrm{I}^{2}=0.0 \%$} \\
\hline \multicolumn{6}{|c|}{ Test for overall effect: $Z=0.34(P=0.74)$} \\
\hline Test for subgroup diff & Vot applicable & & & & \\
\hline
\end{tabular}

\section{$\begin{array}{lllll}0.01 & 0.1 & 1 & 10 & 100\end{array}$}

Favours black cohosh Favours placebo

Analysis 2.I. Comparison 2 Black cohosh versus hormone therapy, Outcome I Vasomotor symptoms: daily hot flush frequency.

Review: Black cohosh (Cimicifuga spp.) for menopausal symptoms

Comparison: 2 Black cohosh versus hormone therapy

Outcome: I Vasomotor symptoms: daily hot flush frequency

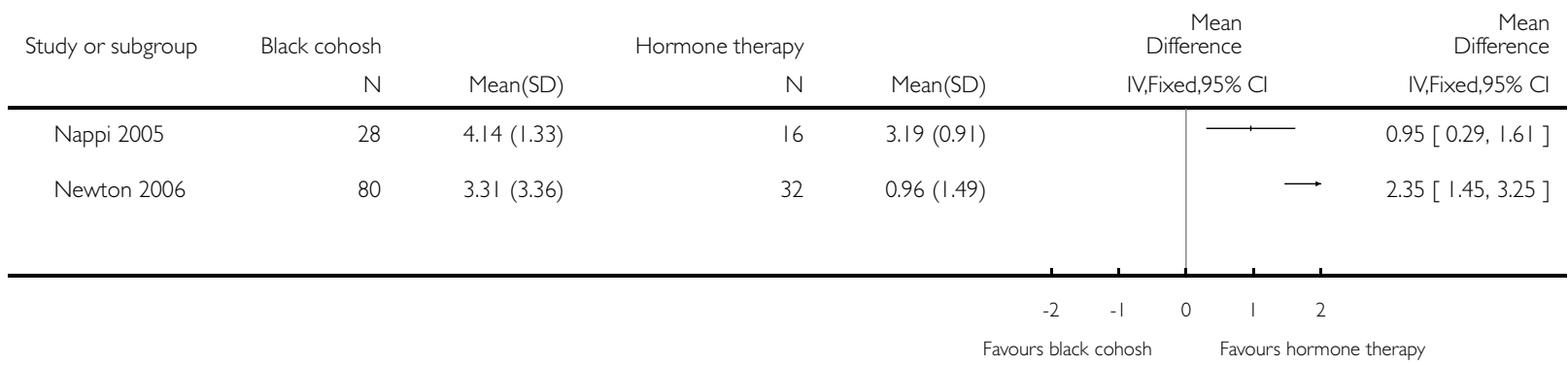




\section{Analysis 2.2. Comparison 2 Black cohosh versus hormone therapy, Outcome 2 Vasomotor symptoms:}

weekly hot flush frequency.

Review: Black cohosh (Cimicifuga spp.) for menopausal symptoms

Comparison: 2 Black cohosh versus hormone therapy

Outcome: 2 Vasomotor symptoms: weekly hot flush frequency

\begin{tabular}{|c|c|c|c|c|c|c|c|c|}
\hline \multirow[t]{2}{*}{ Study or subgroup } & \multirow{2}{*}{$\begin{array}{r}\text { Black cohosh } \\
\mathrm{N}\end{array}$} & \multicolumn{3}{|c|}{ Hormone therapy } & \multicolumn{2}{|c|}{$\begin{array}{r}\text { Mean } \\
\text { Difference }\end{array}$} & \multirow[t]{2}{*}{ Weight } & \multirow{2}{*}{$\begin{array}{r}\text { Mean } \\
\text { Difference } \\
\text { IV,Fixed,95\% Cl }\end{array}$} \\
\hline & & Mean(SD) & $\mathrm{N}$ & Mean(SD) & & $\mathrm{ked}, 95 \% \mathrm{Cl}$ & & \\
\hline Geller 2009 & & $28.77(17.78)$ & 23 & $2.35(4.52)$ & & + & $100.0 \%$ & $26.42[18.59,34.25]$ \\
\hline Total $(95 \%$ CI $)$ & 21 & & 23 & & & $\bullet$ & $100.0 \%$ & $26.42[18.59,34.25]$ \\
\hline \multicolumn{9}{|c|}{ Heterogeneity: not applicable } \\
\hline \multicolumn{9}{|c|}{ Test for overall effect: $Z=6.62(P<0.0000 I)$} \\
\hline \multicolumn{9}{|c|}{ Test for subgroup differences: Not applicable } \\
\hline & & & & -100 & -50 & 50 & 100 & \\
\hline \multicolumn{9}{|c|}{ Favours black cohosh } \\
\hline
\end{tabular}

Analysis 2.3. Comparison 2 Black cohosh versus hormone therapy, Outcome 3 Vasomotor symptoms: hot flush intensity.

Review: Black cohosh (Cimicifuga spp.) for menopausal symptoms

Comparison: 2 Black cohosh versus hormone therapy

Outcome: 3 Vasomotor symptoms: hot flush intensity

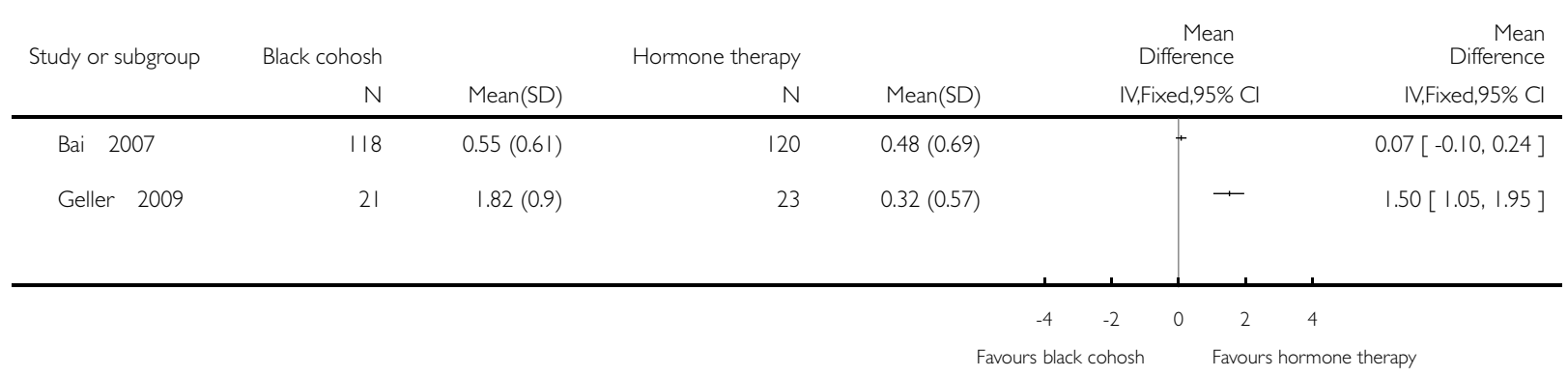


Analysis 2.4. Comparison 2 Black cohosh versus hormone therapy, Outcome 4 Vasomotor symptoms: night sweats.

Review: Black cohosh (Cimicifuga spp.) for menopausal symptoms

Comparison: 2 Black cohosh versus hormone therapy

Outcome: 4 Vasomotor symptoms: night sweats

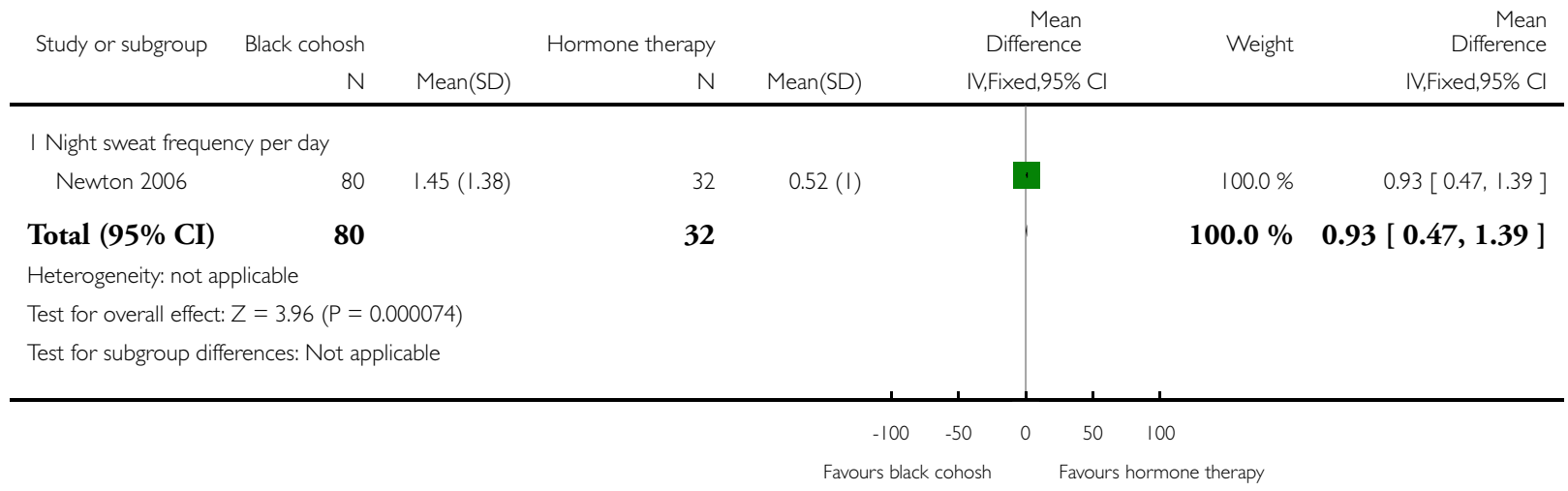




\section{Analysis 2.5. Comparison 2 Black cohosh versus hormone therapy, Outcome 5 Menopausal Symptom Score.}

Review: Black cohosh (Cimicifuga spp.) for menopausal symptoms

Comparison: 2 Black cohosh versus hormone therapy

Outcome: 5 Menopausal Symptom Score

\begin{tabular}{|c|c|c|c|c|c|c|c|}
\hline \multirow[t]{2}{*}{ Study or subgroup } & \multirow{2}{*}{$\begin{array}{r}\text { Black cohosh } \\
N\end{array}$} & \multicolumn{3}{|c|}{ Hormone therapy } & \multirow{2}{*}{$\begin{array}{r}\text { Std. } \\
\text { Mean } \\
\text { Difference } \\
\text { IV,Fixed,95\% Cl }\end{array}$} & \multirow[t]{2}{*}{ Weight } & \multirow{2}{*}{$\begin{array}{r}\text { Std. } \\
\text { Mean } \\
\text { Difference } \\
\text { IV,Fixed,95\% Cl }\end{array}$} \\
\hline & & Mean(SD) & $N$ & Mean(SD) & & & \\
\hline \multicolumn{8}{|l|}{ I Kupperman Index } \\
\hline Bai 2007 & 118 & $7.7 \mid(5.75)$ & 120 & $7.47(6.75)$ & & $55.0 \%$ & $0.04[-0.22,0.29]$ \\
\hline Geller 2009 & 21 & $13.95(5.3)$ & 23 & $9.09(6.29)$ & $\longrightarrow$ & $9.3 \%$ & $0.82[0.20,1.44]$ \\
\hline Lehmann-Willenbrock 1988 & 15 & $29.82(8.1)$ & 15 & $24.43(6.36)$ & & $6.5 \%$ & $0.72[-0.02,1.46]$ \\
\hline Subtotal (95\% CI) & 154 & & 158 & & - & $70.8 \%$ & $0.20[-0.02,0.43]$ \\
\hline \multicolumn{8}{|c|}{ Heterogeneity: $\mathrm{Chi}^{2}=7.28, \mathrm{df}=2(\mathrm{P}=0.03) ; \mathrm{I}^{2}=73 \%$} \\
\hline \multicolumn{8}{|c|}{ Test for overall effect: $Z=1.77(P=0.076)$} \\
\hline \multicolumn{8}{|l|}{2 Greene Climacteric Scale } \\
\hline Nappi 2005 & 28 & $2.79(0.92)$ & 16 & $2.56(0.89)$ & & $9.3 \%$ & $0.25[-0.37,0.87]$ \\
\hline Subtotal (95\% CI) & 28 & & 16 & & & $9.3 \%$ & $0.25[-0.37,0.87]$ \\
\hline \multicolumn{8}{|l|}{ Heterogeneity: not applicable } \\
\hline \multicolumn{8}{|c|}{ Test for overall effect: $Z=0.79(P=0.43)$} \\
\hline \multicolumn{8}{|c|}{3 Wiklund Menopause Symptom Score } \\
\hline Newton 2006 & 80 & $1.78(1.23)$ & 32 & $0.91(0.78)$ & $\because-$ & $19.9 \%$ & $0.77[0.35,1.19]$ \\
\hline Subtotal (95\% CI) & 80 & & 32 & & & $19.9 \%$ & $0.77[0.35,1.19]$ \\
\hline \multicolumn{8}{|l|}{ Heterogeneity: not applicable } \\
\hline \multicolumn{8}{|c|}{ Test for overall effect: $Z=3.57(P=0.00035)$} \\
\hline Total (95\% CI) & 262 & & 206 & & $<$ & $100.0 \%$ & $0.32[0.13,0.51]$ \\
\hline \multicolumn{8}{|c|}{ Heterogeneity: Chi $^{2}=12.75, d f=4(P=0.01) ;\left.\right|^{2}=69 \%$} \\
\hline \multicolumn{8}{|c|}{ Test for overall effect: $Z=3.33(P=0.00088)$} \\
\hline \multicolumn{8}{|c|}{ Test for subgroup differences: $\mathrm{Chi}^{2}=5.47, \mathrm{df}=2(\mathrm{P}=0.07), \mathrm{I}^{2}=63 \%$} \\
\hline & & & & -2 & -1 & 2 & \\
\hline & & & & Favours & cohosh & mone therapy & \\
\hline
\end{tabular}

Black cohosh (Cimicifuga spp.) for menopausal symptoms (Review) 


\section{Analysis 2.6. Comparison 2 Black cohosh versus hormone therapy, Outcome 6 Adverse events.}

Review: Black cohosh (Cimicifuga spp.) for menopausal symptoms

Comparison: 2 Black cohosh versus hormone therapy

Outcome: 6 Adverse events

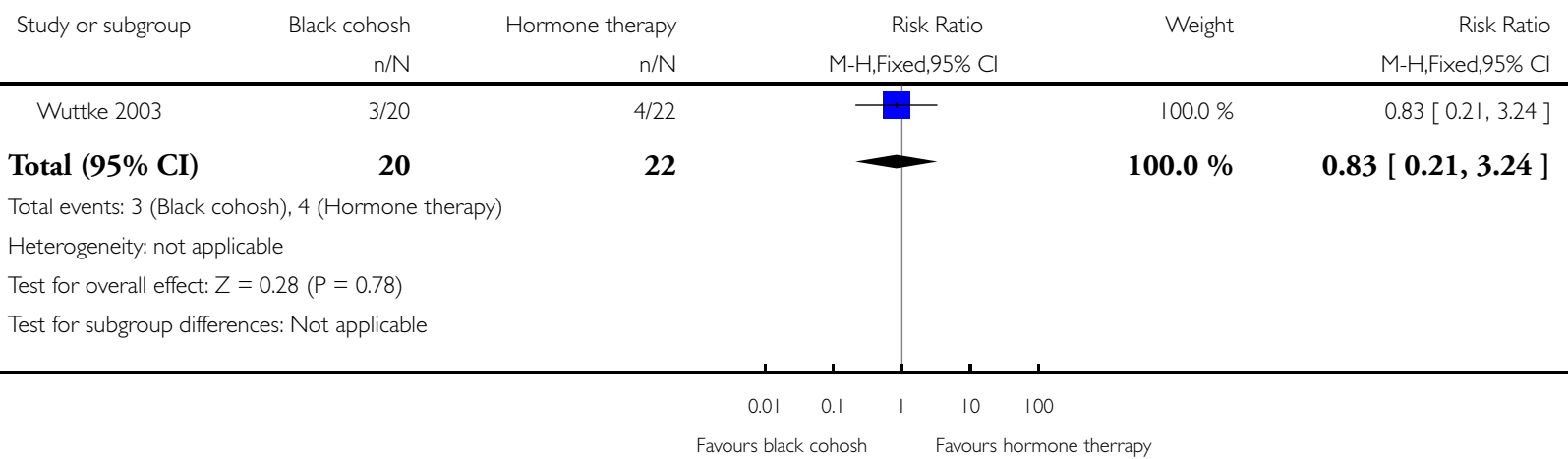

Analysis 3.I. Comparison 3 Black cohosh versus red clover, Outcome I Vasomotor symptoms: hot flush frequency.

Review: Black cohosh (Cimicifuga spp.) for menopausal symptoms

Comparison: 3 Black cohosh versus red clover

Outcome: I Vasomotor symptoms: hot flush frequency

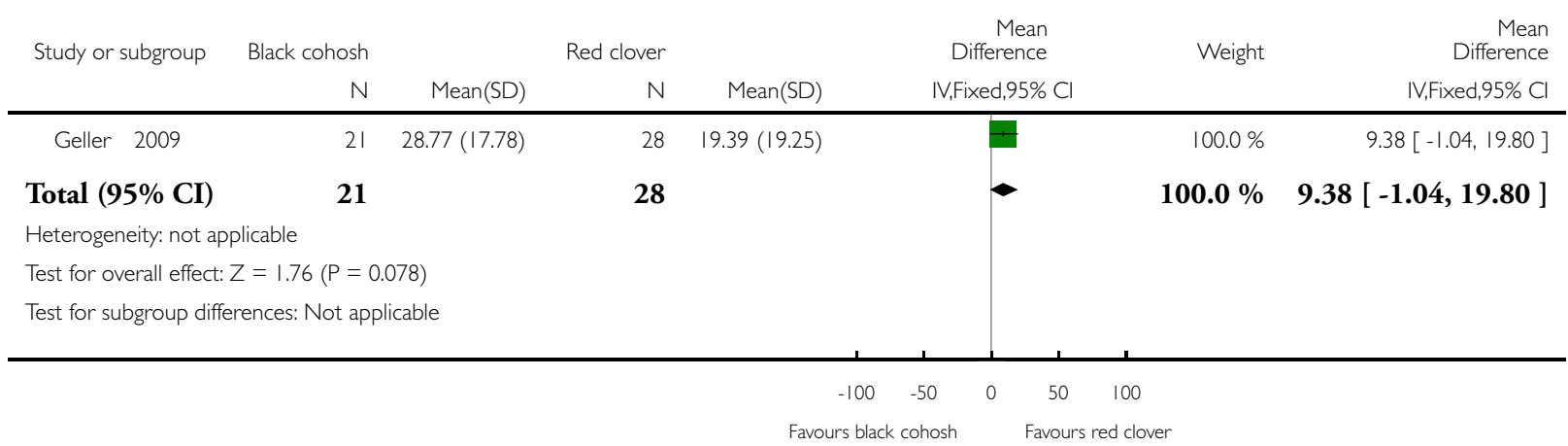


Analysis 3.2. Comparison 3 Black cohosh versus red clover, Outcome 2 Vasomotor symptoms: hot flush intensity.

Review: Black cohosh (Cimicifuga spp.) for menopausal symptoms

Comparison: 3 Black cohosh versus red clover

Outcome: 2 Vasomotor symptoms: hot flush intensity

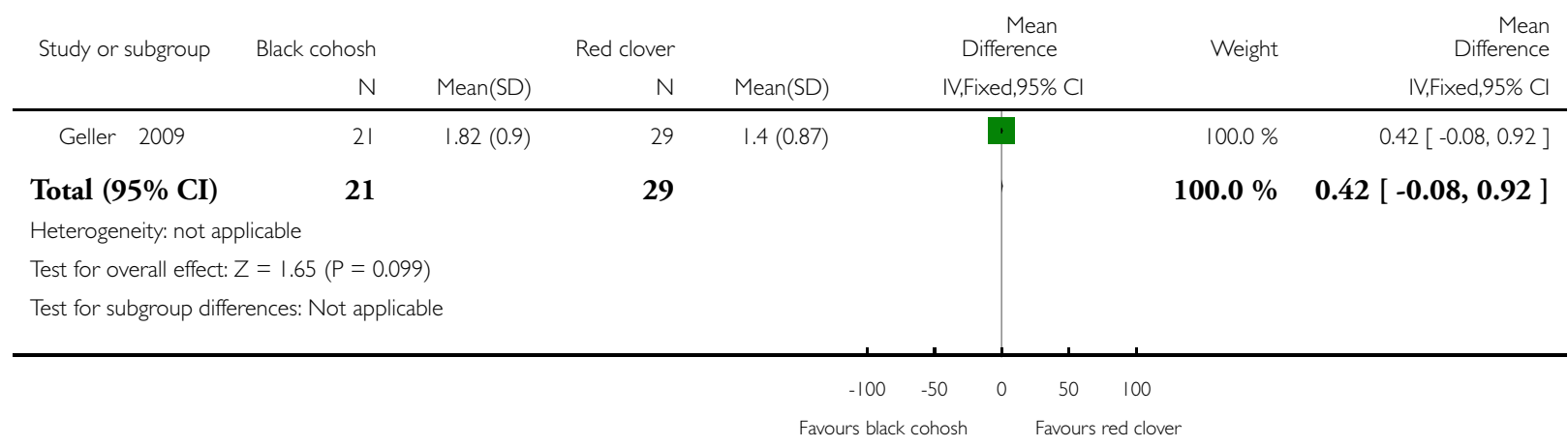

Analysis 3.3. Comparison 3 Black cohosh versus red clover, Outcome 3 Menopausal score.

Review: Black cohosh (Cimicifuga spp.) for menopausal symptoms

Comparison: 3 Black cohosh versus red clover

Outcome: 3 Menopausal score

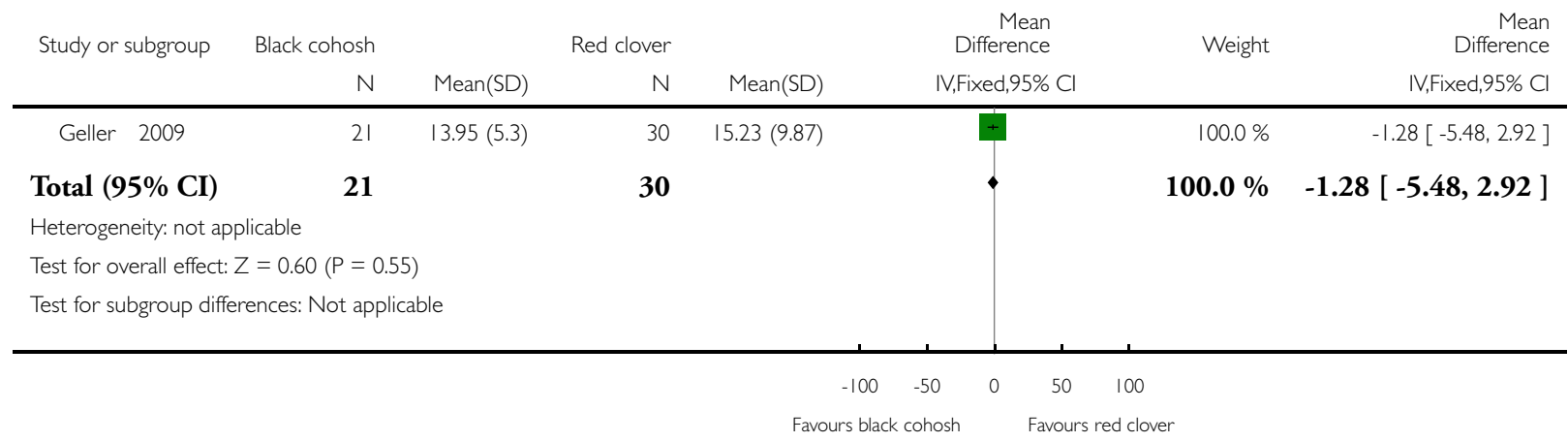

Black cohosh (Cimicifuga spp.) for menopausal symptoms (Review) 
Analysis 4.I. Comparison 4 Black cohosh versus fluoxetine, Outcome I Vasomotor symptoms: night sweats.

\begin{tabular}{|c|c|c|c|c|c|c|c|}
\hline \multicolumn{8}{|c|}{ Comparison: 4 Black cohosh versus fluoxetine } \\
\hline \multicolumn{8}{|c|}{ Outcome: I Vasomotor symptoms: night sweats } \\
\hline \multirow[t]{2}{*}{ Study or subgroup } & \multirow{2}{*}{$\begin{array}{r}\text { Black cohosh } \\
\mathrm{N}\end{array}$} & \multicolumn{3}{|c|}{ Fluoxetine } & $\begin{array}{r}\text { Mean } \\
\text { Difference }\end{array}$ & \multirow[t]{2}{*}{ Weight } & $\begin{array}{r}\text { Mean } \\
\text { Difference }\end{array}$ \\
\hline & & Mean(SD) & N & Mean(SD) & IV,Fixed,95\% Cl & & IV,Fixed,95\% Cl \\
\hline \multicolumn{8}{|c|}{ I Night sweat score per month } \\
\hline Oktem 2007 & 40 & $21.3(30.1)$ & 40 & $106.3(150.3)$ & & $100.0 \%$ & $-85.00[-132.50,-37.50]$ \\
\hline Total $(95 \% \mathrm{CI})$ & 40 & & 40 & & & $100.0 \%$ & $-85.00[-132.50,-37.50]$ \\
\hline \multicolumn{8}{|c|}{ Heterogeneity: not applicable } \\
\hline \multicolumn{8}{|c|}{ Test for overall effect: $Z=3.5 \mathrm{I}(P=0.00045)$} \\
\hline \multicolumn{8}{|c|}{ Test for subgroup differences: Not applicable } \\
\hline
\end{tabular}

Favours fluoxetine

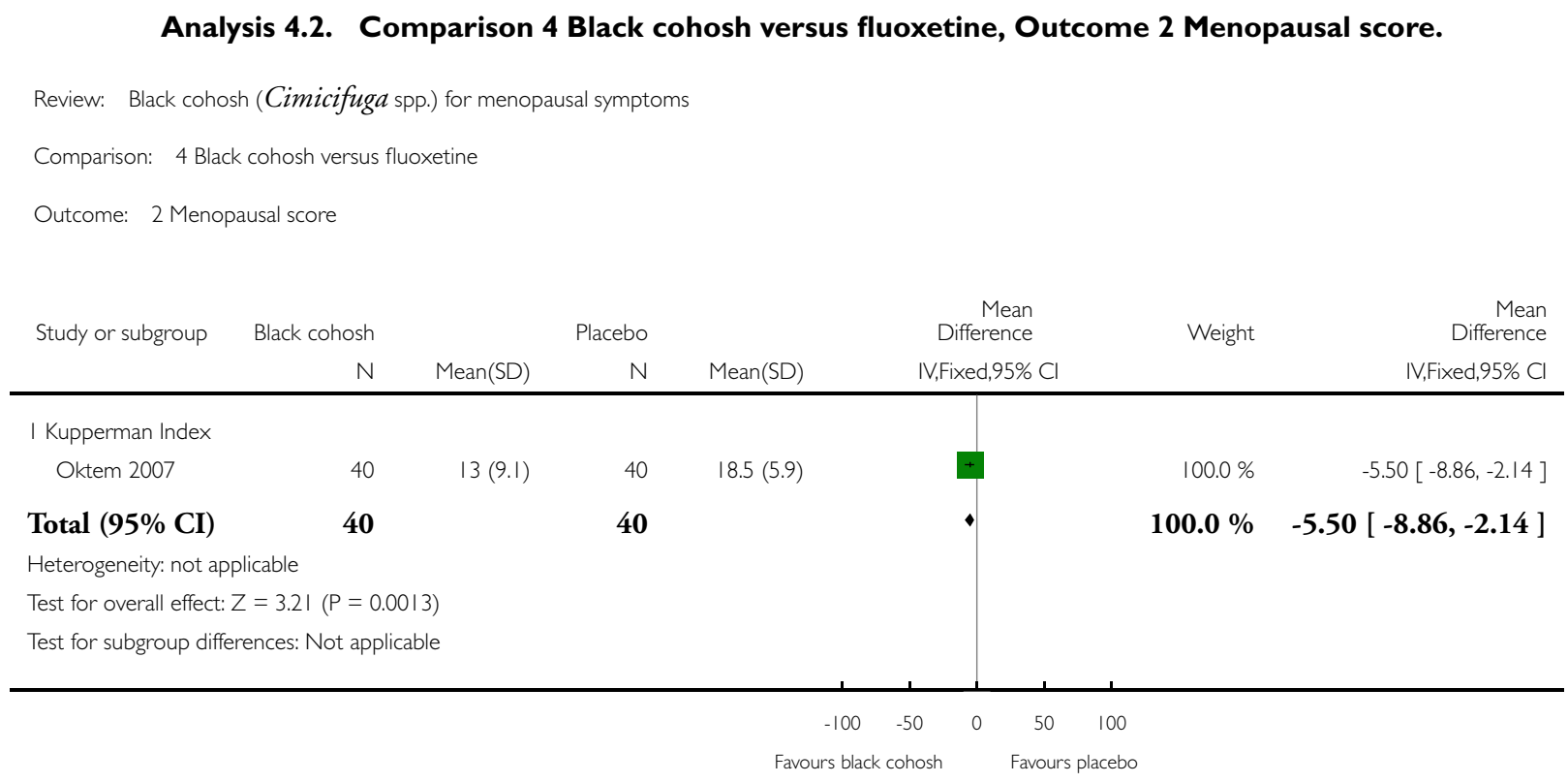

Black cohosh (Cimicifuga spp.) for menopausal symptoms (Review) 


\section{ADDITIONAL TABLES}

Table 1. The Cochrane Collaboration's tool for assessing risk of bias

\begin{tabular}{|c|c|c|}
\hline Domain & Support for judgement & Review authors' judgement \\
\hline \multicolumn{3}{|l|}{ Selection bias } \\
\hline Random sequence generation & $\begin{array}{l}\text { Describe the method used to generate the } \\
\text { allocation sequence in sufficient detail to } \\
\text { allow an assessment of whether it should } \\
\text { produce comparable groups }\end{array}$ & $\begin{array}{l}\text { Selection bias (biased allocation to inter- } \\
\text { ventions) owing to inadequate generation } \\
\text { of a randomised sequence }\end{array}$ \\
\hline Allocation concealment & $\begin{array}{l}\text { Describe the method used to conceal the } \\
\text { allocation sequence in sufficient detail to } \\
\text { determine whether intervention allocations } \\
\text { could have been foreseen in advance of, or } \\
\text { during, enrolment }\end{array}$ & $\begin{array}{l}\text { Selection bias (biased allocation to inter- } \\
\text { ventions) owing to inadequate conceal- } \\
\text { ment of allocations prior to assignment }\end{array}$ \\
\hline \multicolumn{3}{|l|}{ Performance bias } \\
\hline $\begin{array}{l}\text { Blinding of participants and personnel } \\
\text { Assessments should be made for each main } \\
\text { outcome (or class of outcomes) }\end{array}$ & $\begin{array}{l}\text { Describe all measures used, if any, to blind } \\
\text { study participants and personnel from } \\
\text { knowledge of which intervention a partici- } \\
\text { pant received. Provide any information re- } \\
\text { lating to whether the intended blinding was } \\
\text { effective }\end{array}$ & $\begin{array}{l}\text { Performance bias owing to knowledge of } \\
\text { the allocated interventions by participants } \\
\text { and personnel during the study }\end{array}$ \\
\hline \multicolumn{3}{|l|}{ Detection bias } \\
\hline $\begin{array}{l}\text { Blinding of outcome assessment Assess- } \\
\text { ments should be made for each main outcome } \\
\text { (or class of outcomes) }\end{array}$ & $\begin{array}{l}\text { Describe all measures used, if any, to } \\
\text { blind outcome assessors from knowledge } \\
\text { of which intervention a participant re- } \\
\text { ceived. Provide any information relating to } \\
\text { whether the intended blinding was effec- } \\
\text { tive }\end{array}$ & $\begin{array}{l}\text { Detection bias owing to knowledge of the } \\
\text { allocated interventions by outcome asses- } \\
\text { sors }\end{array}$ \\
\hline \multicolumn{3}{|l|}{ Attrition bias } \\
\hline $\begin{array}{l}\text { Incomplete outcome data Assessments } \\
\text { should be made for each main outcome (or } \\
\text { class of outcomes) }\end{array}$ & $\begin{array}{l}\text { Describe the completeness of outcome data } \\
\text { for each main outcome, including attri- } \\
\text { tion and exclusions from the analysis. State } \\
\text { whether attrition and exclusions were re- } \\
\text { ported, the numbers in each intervention } \\
\text { group (compared with total randomised } \\
\text { participants), reasons for attrition/exclu- } \\
\text { sions where reported, and any re-inclusions } \\
\text { in analyses performed by the review authors }\end{array}$ & $\begin{array}{l}\text { Attrition bias owing to amount, nature or } \\
\text { handling of incomplete outcome data }\end{array}$ \\
\hline
\end{tabular}

Reporting bias

Black cohosh (Cimicifuga spp.) for menopausal symptoms (Review) 


\begin{tabular}{|l|l|l|}
\hline Selective reporting & $\begin{array}{l}\text { State how the possibility of selective out- Reporting bias owing to selective outcome } \\
\text { come reporting was examined by the review } \\
\text { authors, and what was found }\end{array}$ \\
\hline Other bias & $\begin{array}{l}\text { State any important concerns about bias Bias owing to problems not covered else- } \\
\text { not addressed in the other domains in the where in the table } \\
\text { tool } \\
\text { If particular questions/entries were pre- } \\
\text { specified in the review's protocol, responses } \\
\text { should be provided for each question/entry }\end{array}$ \\
\hline
\end{tabular}

Table 2. Baseline characteristics A

\begin{tabular}{|c|c|c|c|c|c|}
\hline Study & Interventions & $\begin{array}{l}\text { Age (years), mean } \\
\text { (SD) }\end{array}$ & Ethnic groups (\%) & $\begin{array}{l}\text { Duration of amen- } \\
\text { orrhoea (years), } \\
\text { mean (SD) }\end{array}$ & $\begin{array}{l}\text { Body mass in- } \\
\operatorname{dex}\left(\mathrm{kg} / \mathrm{m}^{2}\right) \text {, mean } \\
(\mathrm{SD})\end{array}$ \\
\hline \multirow[t]{3}{*}{ Amsterdam 2009} & I1: black cohosh & I1: $56.7(6.5)$ & I1: White (71.4) & I1: NR & I1: NR \\
\hline & C1: placebo & C1: 50.8 (3.2) & C1: White (61.5) & $\mathrm{C} 1: \mathrm{NR}$ & C1: NR \\
\hline & & Total: NR & Total: NR & Total: NR & Total: NR \\
\hline \multirow[t]{3}{*}{ Bai 2007} & I1: black cohosh & I1: $51.8(3.7)$ & I1: NR & I1: $2.68(2.05)$ & I1: $23.2(2.3)$ \\
\hline & C1: tibolone & C1: $51.5(3.5)$ & C1: NR & C1: $2.95(2.11)$ & C1: $23.5(2.4)$ \\
\hline & & Total: NR & Total: NR & Total: NR & Total: NR \\
\hline \multirow[t]{4}{*}{ Bebenek 2010} & $\begin{array}{l}\text { I1: exercise + black } \\
\text { cohosh }\end{array}$ & I1: 51.8 (2.7) & I1: NR & I1: NR & I1: NR \\
\hline & I2: exercise only & I2: $52.3(2.3)$ & I2: NR & I2: NR & I2: NR \\
\hline & $\mathrm{C} 1$ : wellness control & C1: $52.4(2.7)$ & C1: NR & C1: NR & $\mathrm{C} 1: \mathrm{NR}$ \\
\hline & & Total: NR & Total: NR & Total: NR & Total: NR \\
\hline \multirow[t]{2}{*}{ Carlisle 2008} & $\begin{array}{l}\text { I1: black cohosh + } \\
\text { calcium and vitamin } \\
\text { D supplement }\end{array}$ & I1: $54.1(5.0)$ & I1: NR & I1: NR & I1: $29.0(5.4)$ \\
\hline & $\begin{array}{l}\mathrm{C} 1: \text { placebo }+ \text { cal- } \\
\text { cium and vitamin D } \\
\text { supplement }\end{array}$ & C1: $52.8(4.4)$ & $\mathrm{C} 1: \mathrm{NR}$ & $\mathrm{C} 1: \mathrm{NR}$ & C1: 29.8 (6.1) \\
\hline
\end{tabular}


Table 2. Baseline characteristics A (Continued)

\begin{tabular}{|c|c|c|c|c|c|}
\hline & & Total: 53.4 (4.7) & Total: NR & Total: NR & Total: $29.4(5.7)$ \\
\hline \multirow[t]{3}{*}{ Frei-Kleiner 2005} & I1: black cohosh & I1: 52.5 (3.7) & I1: NR & I1: $3.23(4.21)$ & I1: NR \\
\hline & C1: placebo & C1: $52.2(3.5)$ & $\mathrm{C} 1: \mathrm{NR}$ & C1: 3.11 (4.28) & $\mathrm{C} 1: \mathrm{NR}$ \\
\hline & & Total: NR & Total: NR & Total: NR & Total: NR \\
\hline \multirow[t]{5}{*}{ Geller 2009} & I1: black cohosh & I1: 54.4 (3.9) & $\begin{array}{l}\text { I1: White (61.9) } \\
\text {, African-American } \\
\text { (38.1), Hispanic (0) }\end{array}$ & I1: $3.4(2.6)$ & I1: $28.3(4.5)$ \\
\hline & I2: red clover & I2: 52.4 (4.6) & $\begin{array}{l}\text { I2: White (22.7) } \\
\text {, African-American } \\
(59.1) \text {, Hispanic } \\
(13.6)\end{array}$ & I2: $4.1(2.8)$ & I2: $30.5(4.3)$ \\
\hline & $\begin{array}{l}\text { I3: conjugated oe- } \\
\text { strogen + MDP }\end{array}$ & I3: $53.3(4.0)$ & $\begin{array}{l}\text { I3: White (69.9) } \\
\text {, African-American } \\
(30.4) \text {, Hispanic (0) }\end{array}$ & I3: $3.6(2.9)$ & I3: $26.0(3.9)$ \\
\hline & C1: placebo & C1: $52.0(4.2)$ & $\begin{array}{l}\text { C1: White (22.7) } \\
\text {, African-American } \\
\text { (72.7), Hispanic ( } 4 . \\
6)\end{array}$ & C1: 2.8 (2.9) & C1: 30.1 (4.9) \\
\hline & & Total: $53.0(4.2)$ & $\begin{array}{l}\text { Total: White (44.3) } \\
\text {, African-American } \\
(50.0) \text {, Hispanic ( } 4 . \\
\text { 5) }\end{array}$ & Total: $3.5(2.8)$ & Total: 28.7 (4.7) \\
\hline \multirow[t]{3}{*}{ Jacobson 2001} & I1: black cohosh & I1: NR & $\begin{array}{l}\text { I1: Euro- } \\
\text { pean-American (71. } \\
\text { 4), Hispanic (16.7) } \\
\text {, African-American } \\
(9.5)\end{array}$ & I1: NR & I1: NR \\
\hline & C1: placebo & C1: NR & & C1: NR & C1: NR \\
\hline & & Total: NR & Total: NR & Total: NR & Total: NR \\
\hline \multirow[t]{2}{*}{ Kronenberg 2009} & I1: black cohosh & I1: $55.1(4.1)$ & $\begin{array}{l}\text { I1: White (86.5), } \\
\text { African (10.8) }\end{array}$ & I1: NR & I1: 25.7 (3.9) \\
\hline & C1: placebo & C1: $54.2(3.6)$ & $\begin{array}{l}\text { C1: White (86.5), } \\
\text { African (5.4) }\end{array}$ & & C1: $24.8(4.0)$ \\
\hline
\end{tabular}


Table 2. Baseline characteristics A (Continued)

\begin{tabular}{|c|c|c|c|c|c|}
\hline & & Total: 54.7 (3.8) & $\begin{array}{l}\text { Total: White (86.5), } \\
\text { African (8.1) }\end{array}$ & Total: NR & Total: $25.2(3.9)$ \\
\hline \multirow{5}{*}{$\begin{array}{l}\text { Lehmann- } \\
\text { Willenbrock } 1988\end{array}$} & I1: black cohosh & I1: NR & I1: NR & I1: NR & I1: NR \\
\hline & C1: oestriol & C1: NR & C1: NR & C1: NR & C1: NR \\
\hline & $\begin{array}{l}\text { C2: conjugated oe- } \\
\text { strogen }\end{array}$ & C2: NR & C2: NR & C2: NR & C2: NR \\
\hline & $\begin{array}{l}\text { C3: oestra- } \\
\text { diol/ norethisterone } \\
\text { acetate }\end{array}$ & C3: NR & C3: NR & C3: NR & C3: NR \\
\hline & & Total: NR & Total: NR & Total: NR & Total: NR \\
\hline \multirow[t]{3}{*}{ Nappi 2005} & I1: black cohosh & I1: $50.5(2.1)$ & I1: NR & I1: NR & I1: $22.9(2.2)$ \\
\hline & $\begin{array}{l}\mathrm{C} 1 \text { : oestradiol + di- } \\
\text { hydrogesterone }\end{array}$ & C1: 50.9 (1.8) & C1: NR & $\mathrm{C} 1: \mathrm{NR}$ & $\mathrm{C} 1: 22.0(2.1)$ \\
\hline & & Total: NR & Total: NR & Total: NR & Total: NR \\
\hline \multirow[t]{6}{*}{$\begin{array}{l}\text { Newton } 2006 \\
\text { Reed } 2008\end{array}$} & I1: black cohosh & I1: $52.0(2.2)$ & $\begin{array}{l}\text { I1: White } \\
\text { (91), African-Amer- } \\
\text { ican (4) }\end{array}$ & I1: NR & I1: $27.3(5.0)$ \\
\hline & I2: multi-botanical & I2: $52.2(2.5)$ & $\begin{array}{l}\text { I2: White } \\
\text { (99), African-Amer- } \\
\text { ican (1) }\end{array}$ & I2: NR & I2: $28.4(6.3)$ \\
\hline & $\begin{array}{l}\text { I3: mult-ibotanical } \\
+ \text { dietary soy }\end{array}$ & I3: $52.5(2.5)$ & $\begin{array}{l}\text { I3: White } \\
(95) \text {, African-Amer- } \\
\text { ican (4) }\end{array}$ & I3: NR & I3: $28.4(5.7)$ \\
\hline & $\begin{array}{l}\text { I4: conjugated oe- } \\
\text { strogen + MDP }\end{array}$ & I4: 52.3 (2.6) & $\begin{array}{l}\text { I4: White } \\
(94) \text {, African-Amer- } \\
\text { ican }(0)\end{array}$ & I4: NR & I4: 31.5 (7.9) \\
\hline & C1: placebo & $\mathrm{C} 1: 52.0(2.5)$ & $\begin{array}{l}\text { C1: White } \\
\text { (88), African-Amer- } \\
\text { ican (2) }\end{array}$ & C1: NR & C1: $29.2(6.4)$ \\
\hline & & Total: $52.2(2.4)$ & $\begin{array}{l}\text { Total: White (93) } \\
\text {, African-American } \\
\text { (3) }\end{array}$ & Total: NR & Total: $28.6(6.2)$ \\
\hline Oktem 2007 & I1: black cohosh & I1: $53.1(5.6)$ & I1: NR & I1: NR & I1: $26.5(3.8)$ \\
\hline
\end{tabular}


Table 2. Baseline characteristics A (Continued)

\begin{tabular}{|c|c|c|c|c|c|}
\hline & C1: fluoxetine & C1: 52.7 (6.4) & C1: NR & C1: NR & C1: $27.8(3.8)$ \\
\hline & & Total: NR & Total: NR & Total: NR & Total: NR \\
\hline \multirow[t]{3}{*}{ Osmers 2005} & I1: black cohosh & I1: $54.6(6.0)$ & I1: NR & I1: NR & I1: $25.5(3.0)$ \\
\hline & C1: placebo & C1: $55.0(6.0)$ & C1: NR & C1: NR & C1: $24.9(2.7)$ \\
\hline & & Total: NR & Total: NR & Total: NR & Total: NR \\
\hline \multirow[t]{3}{*}{ Pockaj 2006} & I1: black cohosh & I1: $56.0(8.3)$ & I1: NR & I1: NR & I1: NR \\
\hline & C1: placebo & C1: 56.7 (8.9) & C1: NR & $\mathrm{C} 1: \mathrm{NR}$ & $\mathrm{C} 1: \mathrm{NR}$ \\
\hline & & Total: 56.4 (8.5) & Total: NR & Total: NR & Total: NR \\
\hline \multirow[t]{4}{*}{ Stoll 1987} & I1: black cohosh & I1: $51.3(3.1)$ & I1: NR & I1: NR & I1: NR \\
\hline & $\mathrm{C} 1$ : oestrogen & C1: $50.3(2.8)$ & $\mathrm{C} 1: \mathrm{NR}$ & C1: NR & C1: NR \\
\hline & C2: placebo & C2: $49.8(3.1)$ & C2: NR & C2: NR & C2: NR \\
\hline & & Total: NR & Total: NR & Total: NR & Total: NR \\
\hline \multirow{4}{*}{$\begin{array}{l}\text { Wuttke 2003/ } \\
\text { 2006a/2006b }\end{array}$} & I1: black cohosh & I1: $52.3(3.2)$ & I1: NR & I1: NR & I1: NR \\
\hline & $\begin{array}{l}\mathrm{C} 1 \text { : conjugated oe- } \\
\text { strogens }\end{array}$ & C1: $52.3(3.0)$ & $\mathrm{C} 1: \mathrm{NR}$ & C1: NR & $\mathrm{C} 1: \mathrm{NR}$ \\
\hline & C2: placebo & C2: $54.1(4.4)$ & C2: NR & C2: NR & C2: NR \\
\hline & & Total: NR & Total: NR & Total: NR & Total: NR \\
\hline
\end{tabular}

C: control; I: intervention; NR: not recorded.

Table 3. Baseline characteristics B

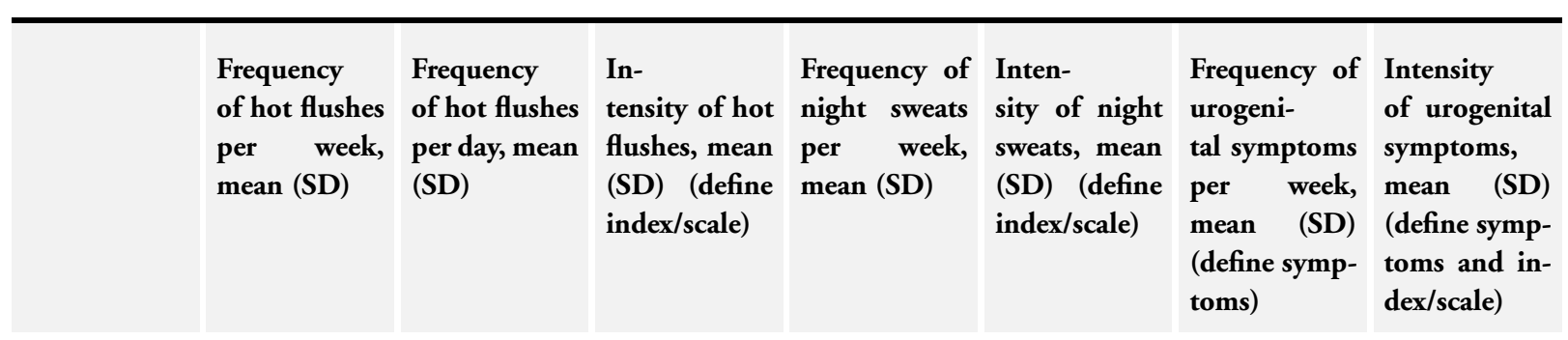


Table 3. Baseline characteristics B (Continued)

\begin{tabular}{|c|c|c|c|c|c|c|c|}
\hline Amsterdam & I1: NR & I1: NR & I1: NR & I1: NR & I1: NR & I1: NR & I1: NR \\
\hline & C1: NR & C1: NR & C1: NR & C1: NR & C1: NR & C1: NR & C1: NR \\
\hline & Total: NR & Total: NR & Total: NR & Total: NR & Total: NR & Total: NR & Total: NR \\
\hline \multirow[t]{3}{*}{ Bai 2007} & I1: $30.0(26.1)$ & I1: NR & I1: NR & I1: NR & I1: NR & I1: NR & I1: NR \\
\hline & $\begin{array}{l}\mathrm{C} 1: 30.1(20 . \\
1)\end{array}$ & C1: NR & $\mathrm{C} 1: \mathrm{NR}$ & $\mathrm{C} 1: \mathrm{NR}$ & C1: NR & $\mathrm{C} 1: \mathrm{NR}$ & $\mathrm{C} 1: \mathrm{NR}$ \\
\hline & Total: NR & Total: NR & Total: NR & Total: NR & Total: NR & Total: NR & Total: NR \\
\hline \multirow[t]{4}{*}{ Bebenek 2010} & I1: NR & I1: NR & I1: NR & I1: NR & I1: NR & I1: NR & I1: NR \\
\hline & I2: NR & I2: NR & I2: NR & I2: NR & I2: NR & I2: NR & I2: NR \\
\hline & $\mathrm{C} 1: \mathrm{NR}$ & $\mathrm{C} 1: \mathrm{NR}$ & $\mathrm{C} 1: \mathrm{NR}$ & C1: NR & $\mathrm{C} 1: \mathrm{NR}$ & $\mathrm{C} 1: \mathrm{NR}$ & C1: NR \\
\hline & Total: NR & Total: NR & Total: NR & Total: NR & Total: NR & Total: NR & Total: NR \\
\hline \multirow[t]{3}{*}{ Carlisle 2008} & I1: NR & I1: NR & I1: NR & I1: NR & I1: NR & I1: NR & I1: NR \\
\hline & C1: NR & C1: NR & C1: NR & C1: NR & C1: NR & C1: NR & C1: NR \\
\hline & Total: NR & Total: NR & Total: NR & Total: NR & Total: NR & Total: NR & Total: NR \\
\hline \multirow{3}{*}{$\begin{array}{l}\text { Frei-Kleiner } \\
2005\end{array}$} & I1: NR & I1: 2.3 (1.9) & I1: NR & I1: NR & I1: NR & I1: NR & I1: NR \\
\hline & $\mathrm{C} 1: \mathrm{NR}$ & $\mathrm{C} 1: 3.5(3.7)$ & $\mathrm{C} 1: \mathrm{NR}$ & C1: NR & $\mathrm{C} 1: \mathrm{NR}$ & $\mathrm{C} 1: \mathrm{NR}$ & C1: NR \\
\hline & Total: NR & Total: NR & Total: NR & Total: NR & Total: NR & Total: NR & Total: NR \\
\hline Geller 2009 & I1: 44.8 (16.7) & I1: NR & $\begin{array}{l}\text { I1: } 2.4 \text { (0.6) } \\
\text { (3-point sever- } \\
\text { ity scale) }\end{array}$ & I1: NR & I1: NR & I1: NR & I1: $0.8(1.0)$ \\
\hline
\end{tabular}


Table 3. Baseline characteristics B (Continued)

\begin{tabular}{|c|c|c|c|c|c|c|c|}
\hline & I2: $40.3(15.4)$ & I2: NR & $\begin{array}{l}\text { I2: } 2.2(0.7) \\
\text { (3-point sever- } \\
\text { ity scale) }\end{array}$ & I2: NR & I2: NR & I2: NR & I2: $1.1(1.0)$ \\
\hline & I3: $52.1(34.5)$ & I3: NR & $\begin{array}{l}\text { I3: } 2.0 \quad(0.7) \\
\text { (3-point sever- } \\
\text { ity scale) }\end{array}$ & I3: NR & I3: NR & I3: NR & I3: $0.7(0.9)$ \\
\hline & $\begin{array}{l}\mathrm{C} 1: 33.7 \text { (14. } \\
1)\end{array}$ & C1: NR & $\begin{array}{l}\mathrm{C} 1: 2.3(0.7) \\
\text { (3-point sever- } \\
\text { ity scale) }\end{array}$ & C1: NR & C1: NR & C1: NR & C1: $1.1(0.9)$ \\
\hline & Total: NR & Total: NR & Total: NR & Total: NR & Total: NR & Total: NR & Total: NR \\
\hline & & & & & & & $\begin{array}{l}\text { (Vaginal dry- } \\
\text { ness, 3-point } \\
\text { scale) }\end{array}$ \\
\hline \multirow{3}{*}{$\begin{array}{l}\text { Jacobson } \\
2001\end{array}$} & I1: NR & I1: NR & I1: NR & I1: NR & I1: NR & I1: NR & I1: NR \\
\hline & C1: NR & C1: NR & C1: NR & C1: NR & C1: NR & C1: NR & C1: NR \\
\hline & Total: NR & Total: NR & Total: NR & Total: NR & Total: NR & Total: NR & Total: NR \\
\hline \multirow{4}{*}{$\begin{array}{l}\text { Kronenberg } \\
2009\end{array}$} & I1: $37.6(18.7)$ & I1: NR & I1: $2.5(1.04)$ & I1: NR & I1: NR & I1: NR & I1: NR \\
\hline & $\begin{array}{l}\mathrm{C} 1: 40.1(16 . \\
6)\end{array}$ & C1: NR & $\mathrm{C} 1: 2.4(0.85)$ & C1: NR & C1: NR & C1: NR & C1: NR \\
\hline & $\begin{array}{ll}\text { Total: } & 38.9 \\
(17.5) & \end{array}$ & Total: NR & $\begin{array}{l}\text { Total: } 2.5(0 . \\
94)\end{array}$ & Total: NR & Total: NR & Total: NR & Total: NR \\
\hline & & & $\begin{array}{l}\text { (scale not de- } \\
\text { fined) }\end{array}$ & & & & \\
\hline \multirow{5}{*}{$\begin{array}{l}\text { Lehmann- } \\
\text { Willenbrock } \\
1988\end{array}$} & I1: NR & I1: NR & I1: NR & I1: NR & I1: NR & I1: NR & I1: NR \\
\hline & C1: NR & C1: NR & C1: NR & C1: NR & C1: NR & C1: NR & C1: NR \\
\hline & C2: NR & C2: NR & C2: NR & C2: NR & C2: NR & C2: NR & C2: NR \\
\hline & C3: NR & C3: NR & C3: NR & C3: NR & C3: NR & C3: NR & C3: NR \\
\hline & Total: NR & Total: NR & Total: NR & Total: NR & Total: NR & Total: NR & Total: NR \\
\hline
\end{tabular}


Table 3. Baseline characteristics B (Continued)

\begin{tabular}{|c|c|c|c|c|c|c|c|}
\hline Nappi 2005 & I1: $10.5(1.5)$ & I1: $11.0(2.7)$ & I1: NR & I1: NR & I1: NR & I1: NR & I1: NR \\
\hline & C1: $11.5(1.0)$ & C1: $10.4(2.3)$ & C1: NR & C1: NR & C1: NR & C1: NR & C1: NR \\
\hline & Total: NR & Total: NR & Total: NR & Total: NR & Total: NR & Total: NR & Total: NR \\
\hline \multirow{6}{*}{$\begin{array}{l}\text { Newton } 2006 \\
\text { / Reed } 2008\end{array}$} & I1: $32.9(17.5)$ & I1: $4.7(3.0)$ & I1: NR & I1: $14.0(8.4)$ & I1: NR & I1: NR & I1: NR \\
\hline & I2: $30.8(21.0)$ & I2: $4.4(3.0)$ & I2: NR & I2: $12.6(7.7)$ & I2: NR & I2: NR & I2: NR \\
\hline & I3: $32.2(22.4)$ & I3: $4.6(3.0)$ & I3: NR & I3: $13.3(8.4)$ & I3: NR & I3: NR & I3: NR \\
\hline & I4: $35.0(30.8)$ & I4: $5.2(4.6)$ & I4: NR & I4: $12.6(7.0)$ & I4: NR & I4: NR & I4: NR \\
\hline & $\begin{array}{l}\mathrm{C} 1: 30.1 \text { (21. } \\
0)\end{array}$ & C1: 4.3 (3.0) & $\mathrm{C} 1: \mathrm{NR}$ & C1: $13.3(8.4)$ & $\mathrm{C} 1: \mathrm{NR}$ & $\mathrm{C} 1: \mathrm{NR}$ & $\mathrm{C} 1: \mathrm{NR}$ \\
\hline & $\begin{array}{ll}\text { Total: } & 32.2 \\
(21.7) & \end{array}$ & Total: NR & Total: NR & $\begin{array}{l}\text { Total: } 13.3(8 . \\
4)\end{array}$ & Total: NR & Total: NR & Total: NR \\
\hline \multirow[t]{3}{*}{ Oktem 2007} & I1: NR & I1: NR & I1: NR & I1: NR & I1: NR & I1: NR & I1: NR \\
\hline & C1: NR & C1: NR & C1: NR & $\mathrm{C} 1: \mathrm{NR}$ & C1: NR & $\mathrm{C} 1: \mathrm{NR}$ & $\mathrm{C} 1: \mathrm{NR}$ \\
\hline & Total: NR & Total: NR & Total: NR & Total: NR & Total: NR & Total: NR & Total: NR \\
\hline \multirow[t]{4}{*}{ Osmers 2005} & I1: NR & I1: NR & I1: NR & I1: NR & I1: NR & I1: NR & I1: NR \\
\hline & C1: NR & C1: NR & C1: NR & C1: NR & C1: NR & C1: NR & C1: NR \\
\hline & Total: NR & Total: NR & Total: NR & Total: NR & Total: NR & Total: NR & Total: NR \\
\hline & $\begin{array}{l}\text { (median re- } \\
\text { ported but no } \\
\text { ranges) }\end{array}$ & & & & & & \\
\hline \multirow[t]{3}{*}{ Pockaj 2006} & I1: NR & I1: 6.7 (3.7) & I1: NR & I1: NR & I1: NR & I1: NR & I1: NR \\
\hline & $\mathrm{C} 1: \mathrm{NR}$ & $\mathrm{C} 1: 6.2(3.6)$ & $\mathrm{C} 1: \mathrm{NR}$ & C1: NR & C1: NR & $\mathrm{C} 1: \mathrm{NR}$ & C1: NR \\
\hline & Total: NR & Total: NR & Total: NR & Total: NR & Total: NR & Total: NR & Total: NR \\
\hline \multirow[t]{3}{*}{ Stoll 1987} & I1: $4.9(-)$ & I1: NR & I1: NR & I1: NR & I1: NR & I1: NR & I1: NR \\
\hline & C1: $5.2(-)$ & C1: NR & C1: NR & C1: NR & C1: NR & $\mathrm{C} 1 \mathrm{NR}$ & C1: NR \\
\hline & C2: $5.1(-)$ & C2: NR & C2: NR & C2: NR & C2: NR & C2: NR & C2: NR \\
\hline
\end{tabular}


Table 3. Baseline characteristics B (Continued)

\begin{tabular}{llllllll}
\hline & Total: NR & Total: NR & Total: NR & Total: NR & Total: NR & Total: NR & Total: NR \\
\hline $\begin{array}{l}\text { Wuttke 2003/ } \\
\text { 2006a/2006b }\end{array}$ & I1: NR & I1: NR & I1: NR & I1: NR & I1: NR & I1: NR & I1: NR \\
\hline & C1: NR & C1: NR & C1: NR & C1: NR & C1: NR & C1: NR & C1: NR \\
\hline
\end{tabular}

C: control; I: intervention; NR: not recorded.

Table 4. Baseline characteristics C

\begin{tabular}{|c|c|c|c|c|c|}
\hline Study & $\begin{array}{l}\text { Intensity of uro- } \\
\text { genital symptoms, } \\
\text { mean (SD) (define } \\
\text { symptoms and in- } \\
\text { dex/scale) }\end{array}$ & $\begin{array}{l}\text { Menopausal symp- } \\
\text { tom score, mean } \\
\text { (SD) (define index/ } \\
\text { scale) }\end{array}$ & $\begin{array}{l}\text { Quality of life, } \\
\text { mean (SD) (define } \\
\text { index/scale) }\end{array}$ & $\begin{array}{l}\text { Sexuality, } \\
\text { mean (SD) (define } \\
\text { outcome measure) }\end{array}$ & $\begin{array}{l}\text { Bone health, mean } \\
\text { (SD) (define out- } \\
\text { come measure) }\end{array}$ \\
\hline \multirow[t]{3}{*}{ Amsterdam 2009} & I1: NR & I1: NR & $\begin{array}{l}\text { I1: } 112.4 \text { (19.5) } \\
\text { (PGWBI) }\end{array}$ & I1: NR & I1: NR \\
\hline & C1: NR & C1: NR & $\begin{array}{l}\text { C1: } 115.2 \\
\text { (PGWBI) }\end{array}$ & C1: NR & C1: NR \\
\hline & Total: NR & Total: NR & Total: NR & Total: NR & Total: NR \\
\hline \multirow[t]{3}{*}{ Bai 2007} & I1: NR & I1: NR & I1: NR & I1: NR & I1: NR \\
\hline & C1: NR & C1: NR & C1: NR & C1: NR & C1: NR \\
\hline & Total: NR & $\begin{array}{lll}\text { Total: } & 24.7 & (6.1) \\
(\mathrm{KI}) & & \end{array}$ & Total: NR & Total: NR & Total: NR \\
\hline \multirow[t]{5}{*}{ Bebenek 2010} & I1: NR & $\begin{array}{l}\text { I1: } 11.86 \quad(4.71) \\
(\mathrm{MRS})\end{array}$ & I1: NR & I1: NR & $\begin{array}{l}\text { I1: } 0.97 \quad(0.13) \\
\text { (BMD, lumbar) }\end{array}$ \\
\hline & & & & & $\begin{array}{l}\text { I1: } \quad 0.77 \quad(0.10) \\
\text { (BMD, fem. head) }\end{array}$ \\
\hline & I2: NR & $\begin{array}{l}\text { I2: } 10.84 \quad(5.35) \\
(M R S)\end{array}$ & I2: NR & I2: NR & $\begin{array}{l}\text { I2: } 0.96 \quad(0.12) \\
(\mathrm{BMD}, \text { lumbar })\end{array}$ \\
\hline & & & & & $\begin{array}{l}\text { I2: } 0.76 \quad(0.10) \\
\text { (BMD, fem. head) }\end{array}$ \\
\hline & C1: NR & $\begin{array}{l}\mathrm{C} 1: \quad 9.88 \quad(3.48) \\
(\mathrm{MRS})\end{array}$ & C1: NR & C1: NR & $\begin{array}{l}\mathrm{C} 1: \quad 0.99 \quad(0.13) \\
(\mathrm{BMD} \text {, lumbar) }\end{array}$ \\
\hline
\end{tabular}


Table 4. Baseline characteristics C (Continued)

\begin{tabular}{|c|c|c|c|c|c|}
\hline & & & & & $\begin{array}{l}\text { C1: } 0.75 \quad(0.11) \\
\text { (BMD, fem. head) }\end{array}$ \\
\hline & Total: NR & Total: NR & Total: NR & Total: NR & Totals: NR \\
\hline \multirow[t]{5}{*}{ Carlisle 2008} & I1: NR & I1: NR & I1: NR & I1: NR & $\begin{array}{l}\text { I1: } \\
10.65(2.78) \text { (serum } \\
\text { osteocalcin, ng/mL) }\end{array}$ \\
\hline & & & & & $\begin{array}{l}\text { I1: } \\
48(0.25) \text { (C-termi- } \\
\text { nal telopeptide, ng/ } \\
\mathrm{mL})\end{array}$ \\
\hline & C1: NR & C1: NR & C1: NR & $\mathrm{C} 1: \mathrm{NR}$ & $\begin{array}{l}\mathrm{C} 1 \mathrm{:} 11.19 \text { (4.16) } \\
\text { (serum osteocalcin, } \\
\mathrm{ng} / \mathrm{mL} \text { ) }\end{array}$ \\
\hline & & & & & $\begin{array}{l}\mathrm{C} 1: 0.56(0.32)(\mathrm{C}- \\
\text { terminal } \\
\text { telopeptide, } \mathrm{ng} / \mathrm{mL})\end{array}$ \\
\hline & Total: NR & Total: NR & Total: NR & Total: NR & Totals: NR \\
\hline \multirow[t]{3}{*}{ Frei-Kleiner 2005} & I1: NR & I1: 19.5 (7.9) (KI) & I1: NR & I1: NR & I1: NR \\
\hline & $\mathrm{C} 1: \mathrm{NR}$ & $\mathrm{C} 1: 19.0(7.2)(\mathrm{KI})$ & $\mathrm{C} 1: \mathrm{NR}$ & $\mathrm{C} 1: \mathrm{NR}$ & $\mathrm{C} 1: \mathrm{NR}$ \\
\hline & Total: NR & Total: NR & Total: NR & Total: NR & Total: NR \\
\hline \multirow[t]{6}{*}{ Geller 2009} & I1: $0.8(1.0)$ & I1: $18.2(5.4)$ & I1: NR & I1: NR & I1: NR \\
\hline & I2: $1.1(1.0)$ & I2: $22.5(8.1)$ & I2: NR & I2: NR & I2: NR \\
\hline & I3: $0.7(0.9)$ & I3: $19.2(7.8)$ & I3: NR & I3: NR & I3: NR \\
\hline & C1: $1.1(0.9)$ & C1: 20.7 (6.6) & C1: NR & C1: NR & C1: NR \\
\hline & Total: NR & Total: NR & Total: NR & Total: NR & Total: NR \\
\hline & $\begin{array}{l}\text { (Vaginal dryness, 3- } \\
\text { point scale) }\end{array}$ & & & & \\
\hline \multirow[t]{3}{*}{ Jacobson 2001} & I1: NR & I1: NR & I1: NR & I1: NR & I1: NR \\
\hline & C1: NR & C1: NR & C1: NR & C1: NR & C1: NR \\
\hline & Total: NR & Total: NR & Total: NR & Total: NR & Total: NR \\
\hline
\end{tabular}


Table 4. Baseline characteristics C (Continued)

\begin{tabular}{|c|c|c|c|c|c|}
\hline Kronenberg 2009 & I1: NR & $\begin{array}{l}\text { I1: } 18.5 \\
(\mathrm{GCS})\end{array}$ & I1: NR & I1: NR & I1: NR \\
\hline & C1: NR & $\begin{array}{l}\mathrm{C} 1: \\
(\mathrm{GCS})\end{array}$ & C1: NR & C1: NR & $\mathrm{C} 1: \mathrm{NR}$ \\
\hline & Total: NR & $\begin{array}{lll}\text { Total: } & 18.8 & (9.2) \\
\text { (GCS) } & & \end{array}$ & Total: NR & Total: NR & Total: NR \\
\hline \multirow[t]{5}{*}{$\begin{array}{l}\text { Lehmann- } \\
\text { Willenbrock } 1988\end{array}$} & I1: NR & $\begin{array}{lll}\mathrm{I} 1: & 48.73 & (8.72) \\
(\mathrm{KI}) & & \end{array}$ & I1: NR & I1: NR & I1: NR \\
\hline & C1: NR & $\begin{array}{lll}\mathrm{C} 1: & 49.12 & (7.76) \\
(\mathrm{KI}) & & \end{array}$ & C1: NR & C1: NR & C1: NR \\
\hline & C2: NR & $\begin{array}{lll}\mathrm{C} 2: & 46.44 & (8.18) \\
(\mathrm{KI}) & & \end{array}$ & C2: NR & $\mathrm{C} 2 \mathrm{NR}$ & C2: NR \\
\hline & C3: NR & $\begin{array}{lll}\text { C3: } & 47.84 & (8.52) \\
(\mathrm{KI}) & & \end{array}$ & C3: NR & C3: NR & C3: NR \\
\hline & Total: NR & Total: NR & Total: NR & Total: NR & Total: NR \\
\hline \multirow[t]{3}{*}{ Nappi 2005} & I1: NR & I1: 7.5 (0.6) (GCS) & I1: NR & I1: NR & I1: NR \\
\hline & C1: NR & C1: 8.0 (0.9) (GCS) & C1: NR & C1: NR & C1: NR \\
\hline & Total: NR & Total: NR & Total: NR & Total: NR & Total: NR \\
\hline \multirow{6}{*}{$\begin{array}{l}\text { Newton } 2006 \\
\text { Reed } 2008\end{array}$} & I1: NR & I1: $2.2(1.2)$ & I1: NR & I1: NR & I1: NR \\
\hline & I2: NR & I2: $2.2(1.1)$ & I2: NR & I2: NR & I2: NR \\
\hline & I3: NR & I3: $2.2(1.2)$ & I3: NR & I3: NR & I3: NR \\
\hline & I4: NR & I4: $2.1(1.0)$ & I4: NR & I4: NR & I4: NR \\
\hline & C1: NR & C1: 2.5 (1.2) & C1: NR & C1: NR & C1: NR \\
\hline & Total: NR & Total: 2.3 (1.2) & Total: NR & Total: NR & Total: NR \\
\hline \multirow[t]{3}{*}{ Oktem 2007} & I1: NR & I1: $25.1(6.7)(\mathrm{mKI})$ & I1: NR & I1: NR & I1: NR \\
\hline & C1: NR & $\begin{array}{l}\mathrm{C} 1: \\
(\mathrm{mKI})\end{array}$ & C1: NR & C1: NR & $\mathrm{C} 1: \mathrm{NR}$ \\
\hline & Total: NR & Total: NR & Total: NR & Total: NR & Total: NR \\
\hline
\end{tabular}


Table 4. Baseline characteristics C (Continued)

\begin{tabular}{|c|c|c|c|c|c|}
\hline Osmers 2005 & I1: NR & $\begin{array}{lll}\mathrm{I} 1: & 0.35 & (0.12) \\
(\mathrm{MRS}) & \end{array}$ & I1: NR & I1: NR & I1: NR \\
\hline & C1: NR & 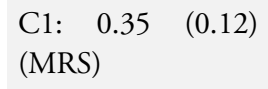 & C1: NR & C1: NR & C1: NR \\
\hline & Total: NR & Total: NR & Total: NR & Total: NR & Total: NR \\
\hline \multirow[t]{3}{*}{ Pockaj 2006} & I1: NR & I1: NR & I1: NR & I1: NR & I1: NR \\
\hline & C1: NR & C1: NR & C1: NR & C1: NR & C1: NR \\
\hline & Total: NR & Total: NR & Total: NR & Total: NR & Total: NR \\
\hline \multirow[t]{4}{*}{ Stoll 1987} & I1: NR & I1: $34.4(-)(\mathrm{KI})$ & I1: NR & I1: 1.9 (-) (NSC) & I1: NR \\
\hline & C1: NR & $\mathrm{C} 1: 34.0(-)(\mathrm{KI})$ & C1: NR & C1: $1.5(-)$ (NSC) & C1: NR \\
\hline & C2: NR & C2: $31.0(-)(\mathrm{KI})$ & C2: NR & C2: $1.6(-)$ (NSC) & C2: NR \\
\hline & Total: NR & Total: NR & Total: NR & Total: NR & Total: NR \\
\hline \multirow[t]{4}{*}{$\begin{array}{l}\text { Wuttke 2003/ } \\
\text { 2006a/2006b }\end{array}$} & I1: NR & $\begin{array}{l}\text { I1: } \quad 2.73 \quad(0.52) \\
\text { (MRS) }\end{array}$ & I1: NR & I1: NR & $\begin{array}{l}\text { I1: } 0.25 \quad(0.2) \\
(\text { CrossLaps, } \mathrm{ng} / \mathrm{mL})\end{array}$ \\
\hline & C1: NR & $\begin{array}{ll}\mathrm{C} 1: & 2.83 \\
(\mathrm{MRS})\end{array}$ & C1: NR & C1: NR & $\begin{array}{l}\text { C1: } 0.24 \quad(0.12) \\
(\text { CrossLaps, } \\
\text { (C) } / \mathrm{mL})\end{array}$ \\
\hline & C2: NR & $\begin{array}{l}\text { C2: } 3.23 \quad(1.0) \\
(\mathrm{MRS})\end{array}$ & C2: NR & $\mathrm{C} 2 \mathrm{NR}$ & $\begin{array}{l}\text { C2: } 0.25 \\
(\text { CrossLaps, } \mathrm{ng} / \mathrm{mL})\end{array}$ \\
\hline & Total: NR & Total: NR & Total: NR & Total: NR & Total: NR \\
\hline
\end{tabular}

BMD: bone mineral density; C: control; GCS: Greene Climacteric Scale; I: intervention; KI: Kupperman Index; MDP: medroxyprogesterone; mKI: Modified Kupperman index; MRS: Menopause Rating Scale; NR: not recorded; NSC: number of sexual complaints; PGWBI: Psychological General Wellbeing Index; WMSS: = Wiklund Menopause Symptom Score.

Table 5. Adverse effects A

\begin{tabular}{|c|c|c|c|c|}
\hline Study & Interventions & $\begin{array}{l}\text { Participants who died } \\
\text { (n) }\end{array}$ & Adverse events (n, \%) & $\begin{array}{l}\text { Serious adverse events } \\
(\mathrm{n}, \%)\end{array}$ \\
\hline \multirow[t]{3}{*}{ Amsterdam 2009} & I1: black cohosh & I1: NR & I1: $14(93 \%)$ & I1: $1(7 \%)$ \\
\hline & $\mathrm{C} 1$ : placebo & $\mathrm{C} 1: \mathrm{NR}$ & C1: $8(62 \%)$ & C1: $0(0 \%)$ \\
\hline & & Total: NR & Total: $22(78 \%)$ & Total: $1(4 \%)$ \\
\hline
\end{tabular}


Table 5. Adverse effects A (Continued)

\begin{tabular}{|c|c|c|c|c|}
\hline Bai 2007 & I1: black cohosh & I1: 0 & I1: $139(-)$ & I1: $0(0 \%)$ \\
\hline & $\mathrm{C} 1$ : tibolone & $\mathrm{C} 1: 0$ & C1: $253(-)$ & C1: $1(0.8 \%)$ \\
\hline & & Total: 0 & Total: $392(-)$ & Total: $1(0.4 \%)$ \\
\hline \multirow[t]{4}{*}{ Bebenek 2010} & $\begin{array}{l}\text { I1: exercise + black co- } \\
\text { hosh }\end{array}$ & I1: NR & I1: $0(0 \%)$ & I1: NR \\
\hline & I2: exercise only & I2: NR & I2: $0(0 \%)$ & I2: NR \\
\hline & $\mathrm{C} 1$ : wellness control & C1: NR & C1: $0(0 \%)$ & C1: NR \\
\hline & & Total: NR & Total: $1(1 \%)$ & Total: NR \\
\hline \multirow[t]{2}{*}{ Carlisle 2008} & $\begin{array}{l}\text { I1: black cohosh + cal- } \\
\text { cium and vitamin D sup- } \\
\text { plement }\end{array}$ & I1: NR & I1: NR & I1: NR \\
\hline & $\begin{array}{l}\mathrm{C} 1 \text { : placebo + calcium } \\
\text { and vitamin D supple- } \\
\text { ment }\end{array}$ & $\mathrm{C} 1: \mathrm{NR}$ & C1: NR & C1: NR \\
\hline \multirow[t]{3}{*}{ Frei-Kleiner 2005} & I1: black cohosh & I1: NR & I1: $17(20 \%)$ & I1: NR \\
\hline & C1: placebo & C1: NR & C1: $10(23 \%)$ & C1: NR \\
\hline & & Total: NR & Total: $27(21 \%)$ & Total: NR \\
\hline \multirow[t]{5}{*}{ Geller 2009} & I1: black cohosh & I1: NR & I1: NR & I1: NR \\
\hline & I2: red clover & I2: NR & I2: NR & I2: NR \\
\hline & $\begin{array}{l}\text { I3: conjugated oestrogen } \\
+ \text { MDP }\end{array}$ & I3: NR & I3: NR & I3: NR \\
\hline & C1: placebo & C1: NR & C1: NR & C1: NR \\
\hline & & Total: NR & Total: NR & Total: NR \\
\hline \multirow[t]{3}{*}{ Jacobson 2001} & I1: black cohosh & I1: NR & I1: $10(24 \%)$ & I1: $2(5 \%)$ \\
\hline & C1: placebo & C1: NR & $\mathrm{C} 1: 3(7 \%)$ & C1: $1(2 \%)$ \\
\hline & & Total: NR & Total: $13(15 \%)$ & Total: $3(4 \%)$ \\
\hline Kronenberg 2009 & I1: black cohosh & I1: NR & I1: $19(31 \%)$ & I1: $0(0 \%)$ \\
\hline
\end{tabular}


Table 5. Adverse effects A (Continued)

\begin{tabular}{|c|c|c|c|c|}
\hline & C1: placebo & C1: NR & C1: $34(50 \%)$ & C1: $0(0 \%)$ \\
\hline & & Total: NR & Total: $53(41 \%)$ & Total: $0(0 \%)$ \\
\hline \multirow{5}{*}{$\begin{array}{l}\text { Lehmann-Willenbrock } \\
1988\end{array}$} & I1: black cohosh & I1: NR & I1: NR & I1: NR \\
\hline & $\mathrm{C} 1$ : oestriol & C1: NR & $\mathrm{C} 1 \mathrm{NR}$ & $\mathrm{C} 1 \mathrm{NR}$ \\
\hline & $\begin{array}{l}\text { C2: conjugated oestro- } \\
\text { gen }\end{array}$ & $\mathrm{C} 2 \mathrm{NR}$ & $\mathrm{C} 2 \mathrm{NR}$ & $\mathrm{C} 2: \mathrm{NR}$ \\
\hline & $\begin{array}{l}\text { C3: oestradiol/ norethis- } \\
\text { terone acetate }\end{array}$ & C3: NR & C3: NR & C3: NR \\
\hline & & Total: NR & Total: NR & Total: NR \\
\hline \multirow[t]{3}{*}{ Nappi 2005} & I1: black cohosh & I1: NR & I1: $0(0 \%)$ & I1: NR \\
\hline & $\begin{array}{l}\mathrm{C} 1 \text { : oestradiol + dihy- } \\
\text { drogesterone }\end{array}$ & C1: NR & C1: $2(6 \%)$ & $\mathrm{C} 1 \mathrm{NR}$ \\
\hline & & Total: NR & Total: $2(3 \%)$ & Total: NR \\
\hline \multirow{6}{*}{$\begin{array}{l}\text { Newton } 2006 \text { / Reed } \\
2008\end{array}$} & I1: black cohosh & I1: NR & I1: 57 (NR) & I1: $0(0 \%)$ \\
\hline & I2: multi-botanical & I2: NR & I2: 44 (NR) & I2: $1(1 \%)$ \\
\hline & $\begin{array}{l}\text { I3: mult-ibotanical + di- } \\
\text { etary soy }\end{array}$ & I3: NR & I3: 57 (NR) & I3: 1 (1\%) \\
\hline & $\begin{array}{l}\text { I4: conjugated oestrogen } \\
+\mathrm{MDP}\end{array}$ & I4: NR & I4: 41 (NR) & I4: 0 (0\%) \\
\hline & C1: placebo & $\mathrm{C} 1 \mathrm{NR}$ & C1: 67 (NR) & C1: $0(0 \%)$ \\
\hline & & Total: NR & Total: 266 (NR) & Total: $2(0.6 \%)$ \\
\hline \multirow[t]{3}{*}{ Oktem 2007} & I1: black cohosh & I1: NR & I1: $7(18 \%)$ & I1: NR \\
\hline & C1: fluoxetine & C1: NR & C1: 13 (33\%) & $\mathrm{C} 1: \mathrm{NR}$ \\
\hline & & Total: NR & Total: $20(25 \%)$ & Total: NR \\
\hline \multirow[t]{2}{*}{ Osmers 2005} & I1: black cohosh & I1: NR & I1: 71 (33\%) & I1: $0(0 \%)$ \\
\hline & C1: placebo & C1: NR & C1: 67 (31\%) & C1: $0(0 \%)$ \\
\hline
\end{tabular}


Table 5. Adverse effects A

(Continued)

\begin{tabular}{|c|c|c|c|c|}
\hline & & Total: NR & Total: 138 (45\%) & Total: $0(0 \%)$ \\
\hline \multirow[t]{3}{*}{ Pockaj 2006} & I1: black cohosh & I1: NR & I1: NR & I1: NR \\
\hline & C1: placebo & C1: NR & C1: NR & C1: NR \\
\hline & & Total: NR & Total: NR & Total: NR \\
\hline \multirow[t]{4}{*}{ Stoll 1987} & I1: black cohosh & I1: NR & I1: NR & I1: NR \\
\hline & C1: oestrogen & $\mathrm{C} 1 \mathrm{NR}$ & $\mathrm{C} 1 \mathrm{NR}$ & $\mathrm{C} 1 \mathrm{NR}$ \\
\hline & C2: placebo & $\mathrm{C} 2 \mathrm{NR}$ & $\mathrm{C} 2 \mathrm{NR}$ & C2: NR \\
\hline & & Total: NR & Total: NR & Total: NR \\
\hline \multirow{4}{*}{$\begin{array}{l}\text { Wuttke } \\
2006 \mathrm{~b}\end{array}$} & I1: black cohosh & I1: NR & I1: $6(15 \%)$ & I1: $0(0 \%)$ \\
\hline & $\begin{array}{l}\text { C1: conjugated oestro- } \\
\text { gens }\end{array}$ & $\mathrm{C} 1 \mathrm{NR}$ & C1: $8(18 \%)$ & $\mathrm{C} 1: 0(0 \%)$ \\
\hline & C2: placebo & $\mathrm{C} 2 \mathrm{NR}$ & C2: $6(15 \%)$ & C2: $0(0 \%)$ \\
\hline & & Total: NR & Total: $20(32 \%)$ & Total: $0(0 \%)$ \\
\hline
\end{tabular}

C: control; I: intervention; NR: not recorded.

Table 6. Adverse effects B

\begin{tabular}{|c|c|c|c|c|c|}
\hline Study & Interventions & $\begin{array}{l}\text { Left study because } \\
\text { of adverse events } \\
(\mathrm{n}, \%)\end{array}$ & $\begin{array}{l}\text { Hospitalised (n, } \\
\%)\end{array}$ & $\begin{array}{l}\text { Symptoms } \\
\text { reported }(\mathbf{n}, \%)\end{array}$ & Notes \\
\hline Amsterdam 2009 & I1: black cohosh & I1: $1(7 \%)$ & I1: NR & $\begin{array}{l}\text { I1: light headedness } \\
(2,15 \%) \text {, difficulty } \\
\text { falling asleep (2, } \\
15 \%) \text {, dry mouth } \\
(1,8 \%) \text {, diaphore- } \\
\text { sis }(1,8 \%) \text {, pain } \\
(1,8 \%) \text {, oedema, } \\
\text { GI bloating (1,8\%) } \\
\text {, diarrhoea }(1,8 \%) \\
\text {, abdominal cramp- } \\
\text { ing (1, 8\%), vagi- } \\
\text { nal bleeding }(1,8 \%) \\
\text {, mid-night waken- }\end{array}$ & \\
\hline
\end{tabular}


Table 6. Adverse effects B (Continued)

\begin{tabular}{|c|c|c|c|c|}
\hline & & & & $\begin{array}{l}\text { ing }(1,8 \%) \text {, anxiety } \\
(1,8 \%)\end{array}$ \\
\hline & C1: placebo & C1: $0(0 \%)$ & $\mathrm{C} 1 \mathrm{NR}$ & $\begin{array}{l}\text { C1: menstrual flow } \\
(2, \quad 15.4 \%) \text {, irri- } \\
\text { tability }(1,8 \%) \text {, list- } \\
\text { lessness }(1,8 \%) \text {, flu } \\
\text { symptoms }(1,8 \%) \\
\text { breast tenderness } \\
(1,8 \%) \text {, constipa- } \\
\text { tion }(1,8 \%) \text {, vaginal } \\
\text { spotting }(1,8 \%)\end{array}$ \\
\hline & & Total: $1(4 \%)$ & Total: NR & \\
\hline \multirow[t]{3}{*}{ Bai 2007} & I1: black cohosh & I1: $5(6 \%)$ & I1: NR & $\begin{array}{l}\text { I1: breast pain/en- } \\
\text { largement } \\
(32,21 \%) \text {, abdomi- } \\
\text { nal pain }(12,10 \%) \text {, } \\
\text { vaginal bleeding }(6 \text {, } \\
5 \%) \text {, vaginal spot- } \\
\text { ting (11, } 7 \%) \\
\text {, oedema }(7,5 \%) \text {, } \\
\text { leucorrhoea }(7,6 \%)\end{array}$ \\
\hline & C1: tibolone & C1: $9(7 \%)$ & $\mathrm{C} 1 \mathrm{NR}$ & $\begin{array}{l}\text { C1: breast pain/en- } \\
\text { largement } \\
(48,35 \%) \text {, vaginal } \\
\text { bleeding }(40,23 \%) \text {, } \\
\text { abdominal pain (30, } \\
24 \%) \text {, leucorrhoea } \\
(27,18 \%) \text {, vaginal } \\
\text { spotting }(21,13 \%) \text {, } \\
\text { oedema }(17,12 \%)\end{array}$ \\
\hline & & Total: 14 (6\%) & Total: NR & \\
\hline \multirow[t]{4}{*}{ Bebenek 2010} & $\begin{array}{l}\text { I1: exercise + black } \\
\text { cohosh }\end{array}$ & I1: NR & I1: NR & I1: NR \\
\hline & I2: exercise only & I2: NR & I2: NR & I2: NR \\
\hline & C1: wellness control & $\mathrm{C} 1 \mathrm{NR}$ & $\mathrm{C} 1 \mathrm{NR}$ & C1: NR \\
\hline & & Total: NR & Total: NR & \\
\hline Carlisle 2008 & $\begin{array}{l}\text { I1: black cohosh + } \\
\text { calcium and vitamin } \\
\text { D supplement }\end{array}$ & I1: NR & I1: NR & I1: NR \\
\hline
\end{tabular}


Table 6. Adverse effects B

(Continued)

\begin{tabular}{|c|c|c|c|c|c|}
\hline & $\begin{array}{l}\mathrm{C} 1: \text { placebo }+ \text { cal- } \\
\text { cium and vitamin D } \\
\text { supplement }\end{array}$ & C1: NR & C1: NR & $\mathrm{C} 1: \mathrm{NR}$ & \\
\hline \multirow[t]{3}{*}{ Frei-Kleiner 2005} & I1: black cohosh & I1: NR & I1: NR & I1: NR & \\
\hline & C1: placebo & C1: NR & C1: NR & C1: NR & \\
\hline & & Total: NR & Total: NR & & \\
\hline \multirow[t]{5}{*}{ Geller 2009} & I1: black cohosh & I1: $0(0 \%)$ & I1: NR & I1: NR & \\
\hline & I2: red clover & I2: $0(0 \%)$ & I2: NR & I2: NR & \\
\hline & $\begin{array}{l}\text { I3: conjugated oe- } \\
\text { strogen + MDP }\end{array}$ & I3: $1(4 \%)$ & I3: NR & I3: NR & \\
\hline & C1: placebo & C1: $0(0 \%)$ & C1: NR & C1: NR & \\
\hline & & Total: & Total: NR & & \\
\hline \multirow[t]{3}{*}{ Jacobson 2001} & I1: black cohosh & I1: $3(7 \%)$ & I1: NR & $\begin{array}{l}\text { I1: hysterectomy (1, } \\
2 \%) \text {, breast cancer } \\
\text { recurrence }(1,2 \%) \\
\text {, constipation (1, } \\
2 \%) \text {, arrhythmia (1, } \\
2 \%) \text {, weight gain } \\
(1,2 \%) \text {, endome- } \\
\text { trial hyperplasia (1, } \\
2 \%) \text {, dilatation and } \\
\text { curettage }(1,2 \%) \text {, } \\
\text { cramping (1, 2\%), } \\
\text { indigestion }(1,2 \%) \text {, } \\
\text { vaginal bleeding (1, } \\
2 \%)\end{array}$ & $\begin{array}{l}\text { The majority of par- } \\
\text { ticipants were also } \\
\text { taking tamoxifen }\end{array}$ \\
\hline & C1: placebo & C1: $1(2 \%)$ & C1: NR & $\begin{array}{l}\text { C1: appendectomy } \\
(1,2 \%) \text {, swollen fin- } \\
\text { ger }(1,2 \%) \text {, abdom- } \\
\text { inal rash }(1,2 \%)\end{array}$ & \\
\hline & & Total: $4(5 \%)$ & Total: NR & & \\
\hline Kronenberg 2009 & I1: black cohosh & I1: NR & I1: NR & $\begin{array}{l}\text { I1: up- } \\
\text { per respiratory in- } \\
\text { fection }(5,8 \%) \text {, skin } \\
\text { complaints }(4,7 \%) \\
\text {, vaginal bleeding }\end{array}$ & \\
\hline
\end{tabular}


Table 6. Adverse effects B (Continued)

\begin{tabular}{|c|c|c|c|c|}
\hline & & & & $\begin{array}{l}(4,7 \%) \text {, vaginitis } \\
(1,2 \%) \text {, abnormal } \\
\text { ECG }(2,3 \%) \text {, in- } \\
\text { creased endometrial } \\
\text { thickness }(3,5 \%)\end{array}$ \\
\hline & C1: placebo & $\mathrm{C} 1: \mathrm{NR}$ & C1: NR & $\begin{array}{l}\text { C1: upper respira- } \\
\text { tory infection (12, } \\
18 \%) \text {, skin com- } \\
\text { plaints (11, 16\%) } \\
\text {, vaginitis (4, 6\%), } \\
\text { abnormal ECG (3, } \\
4 \%) \text {, elevated liver } \\
\text { enzymes (2, 3\%), } \\
\text { vaginal bleeding (1, } \\
2 \%) \text {, increased en- } \\
\text { dometrial thickness } \\
(1,2 \%)\end{array}$ \\
\hline & & Total: NR & Total: NR & \\
\hline \multirow{5}{*}{$\begin{array}{l}\text { Lehmann- } \\
\text { Willenbrock } 1988\end{array}$} & I1: black cohosh & & I1: NR & I1: NR \\
\hline & C1: oestriol & $\mathrm{C} 1 \mathrm{NR}$ & $\mathrm{C} 1 \mathrm{NR}$ & C1: NR \\
\hline & $\begin{array}{l}\text { C2: conjugated oe- } \\
\text { strogen }\end{array}$ & $\mathrm{C} 2 \mathrm{NR}$ & $\mathrm{C} 2 \mathrm{NR}$ & $\mathrm{C} 2 \mathrm{NR}$ \\
\hline & $\begin{array}{l}\text { C3: oestra- } \\
\text { diol/ norethisterone } \\
\text { acetate }\end{array}$ & C3: NR & C3: NR & C3: NR \\
\hline & & Total: NR & Total: NR & \\
\hline \multirow[t]{3}{*}{ Nappi 2005} & I1: black cohosh & I1: NR & I1: NR & I1: NA \\
\hline & $\begin{array}{l}\mathrm{C} 1 \text { : oestradiol + di- } \\
\text { hydrogesterone }\end{array}$ & $\mathrm{C} 1 \mathrm{NR}$ & C1: NR & $\begin{array}{l}\text { C1: vaginal spotting } \\
(2,6 \%)\end{array}$ \\
\hline & & Total: NR & Total: NR & \\
\hline $\begin{array}{l}\text { Newton } 2006 \quad / \\
\text { Reed } 2008\end{array}$ & I1: black cohosh & I1: NR & I1: NR & $\begin{array}{l}\text { I1: menstrual dis- } \\
\text { orders (10, NR), } \\
\text { GI upset }(12, \mathrm{NR}) \\
\text {, headache (12, NR) } \\
\text {, fatigue (12, NR), } \\
\text { myalgia / arthralgia } \\
(11, \mathrm{NR})\end{array}$ \\
\hline
\end{tabular}


Table 6. Adverse effects B

(Continued)

\begin{tabular}{|c|c|c|c|}
\hline I2: multi-botanical & I2: NR & I2: NR & $\begin{array}{l}\text { I2: menstrual disor- } \\
\text { ders (8, NR), breast } \\
\text { discomfort (1, NR) } \\
\text {, GI upset }(11, N R) \\
\text {, headache }(8, N R) \\
\text {, fatigue ( } 7, \mathrm{NR}) \text {, } \\
\text { myalgia / arthralgia } \\
(9, N R)\end{array}$ \\
\hline $\begin{array}{l}\text { I3: mult-ibotanical } \\
+ \text { dietary soy }\end{array}$ & I3: NR & I3: NR & $\begin{array}{l}\text { I3: menstrual disor- } \\
\text { ders (14, NR) } \\
\text {, breast discomfort } \\
(2, \mathrm{NR}), \text { GI upset } \\
(8, \mathrm{NR}) \text {, headache } \\
(12, \quad \text { NRI4: } \\
\text { menstrual disorders } \\
\text { (19, NR), breast dis- } \\
\text { comfort (5, NR), } \\
\text { GI upset (4, NR) } \\
\text {, headache (6, NR) } \\
\text {, fatigue (6, NR) } \\
\text {, myalgia / arthral- } \\
\text { gia (1, NR)), fatigue } \\
\text { (12, NR), myalgia / } \\
\text { arthralgia (9, NR) }\end{array}$ \\
\hline $\begin{array}{l}\text { I4: conjugated oe- } \\
\text { strogen + MDP }\end{array}$ & I4: NR & I4: NR & $\begin{array}{l}\text { I4: menstrual disor- } \\
\text { ders } \\
(19, \mathrm{NR}) \text {, breast dis- } \\
\text { comfort (5, NR), } \\
\text { GI upset }(4, \mathrm{NR}) \\
\text {, headache (6, NR) } \\
\text {, fatigue (6, NR), } \\
\text { myalgia / arthralgia } \\
(1, N R)\end{array}$ \\
\hline C1: placebo & $\mathrm{C} 1 \mathrm{NR}$ & $\mathrm{C} 1 \mathrm{NR}$ & $\begin{array}{l}\text { C1: menstrual dis- } \\
\text { orders (17, NR), } \\
\text { headache (16, NR), } \\
\text { GI upset (13, NR), } \\
\text { myalgia / arthralgia } \\
\text { (10, NR), fatigue ( } 8 \text {, } \\
\text { NR), breast discom- } \\
\text { fort (3, NR) }\end{array}$ \\
\hline
\end{tabular}

Total: NR

Total: NR

Black cohosh (Cimicifuga spp.) for menopausal symptoms (Review) 
Table 6. Adverse effects B

(Continued)

\begin{tabular}{|c|c|c|c|c|}
\hline \multirow[t]{2}{*}{ Oktem 2007} & \multirow{2}{*}{$\begin{array}{l}\text { I1: black cohosh } \\
\text { C1: fluoxetine }\end{array}$} & \multirow{2}{*}{$\begin{array}{l}\text { I1: NR } \\
\\
\text { C1: NR }\end{array}$} & \multirow{2}{*}{$\begin{array}{l}\text { I1: NR } \\
\\
\text { C1: NR }\end{array}$} & $\begin{array}{l}\text { I1: } \quad \text { dyspepsia } \\
(2,5 \%) \text {, constipa- } \\
\text { tion }(2,5 \%) \text {, tired- } \\
\text { ness }(1,3 \%) \text {, skin al- } \\
\text { lergy }(1,3 \%) \text {, irri- } \\
\text { tability }(1,3 \%)\end{array}$ \\
\hline & & & & $\begin{array}{l}\text { C1: dyspepsia } \\
(1,3 \%), \text { constipa- } \\
\text { tion }(1,3 \%), \text { sleep } \\
\text { disturbance }(3,8 \%) \\
\text {, dry mouth }(2,5 \%) \\
\text { tiredness }(2,5 \%) \text {, } \\
\text { skin allergy }(2,5 \%) \\
\text {, irritability }(1,3 \%) \\
\text {, headache }(1,3 \%)\end{array}$ \\
\hline & & Total: NR & Total: NR & \\
\hline \multirow[t]{2}{*}{ Osmers 2005} & I1: black cohosh & I1: 7 (5\%) & I1: NR & $\begin{array}{l}\text { I1: musculoskeletal } \\
\text { disorder }(15,10 \%) \\
\text { infection }(13,9 \%) \text {, } \\
\text { GI disorder }(8,5 \%) \text {, } \\
\text { nervous system dis- } \\
\text { or- } \\
\text { der }(4,3 \%) \text {, repro- } \\
\text { ductive / breast dis- } \\
\text { order }(4,3 \%) \text {, skin } \\
\text { disorder (3, 2\%), } \\
\text { psychiatric disorder } \\
(2,1 \%) \text {, tachycardia } \\
(2,1 \%) \text { metabolic } \\
/ \text { nutrition disorder } \\
(2,1 \%), \text { blood dis- } \\
\text { order }(1,1 \%) \text {, renal/ } \\
\text { urinary disorder }(1, \\
1 \%) \text {, vascular disor- } \\
\text { der }(1,1 \%)\end{array}$ \\
\hline & C1: placebo & C1: $5(3 \%)$ & $\mathrm{C} 1 \mathrm{NR}$ & $\begin{array}{l}\text { C1: in- } \\
\text { fection (19, 13\%), } \\
\text { musculoskeletal dis- } \\
\text { order }(10,7 \%) \text { GI } \\
\text { disorder (7, 5\%), } \\
\text { nervous system dis- } \\
\text { order }(5,3 \%) \text {, psy- } \\
\text { chiatric disorder (5, } \\
3 \%) \text {, reproductive / }\end{array}$ \\
\hline
\end{tabular}

Black cohosh (Cimicifuga spp.) for menopausal symptoms (Review) 
Table 6. Adverse effects B (Continued)

breast disorder (4, $3 \%)$, skin disorder (3, $2 \%)$, blood disorder $(1,1 \%)$, ear/ labyrinth disorder $(1,1 \%)$, vascular disorder $(1,1 \%)$, respiratory disorder $(1,1 \%)$

\begin{tabular}{|c|c|c|c|c|}
\hline & & Total: $12(4 \%)$ & Total: NR & \\
\hline \multirow[t]{3}{*}{ Pockaj 2006} & I1: black cohosh & I1: NR & I1: NR & I1: NR \\
\hline & C1: placebo & C1: NR & C1: NR & C1: NR \\
\hline & & Total: NR & Total: NR & \\
\hline \multirow[t]{4}{*}{ Stoll 1987} & I1: black cohosh & I1: $1(3 \%)$ & I1: NR & I1: NR \\
\hline & $\mathrm{C} 1$ : oestrogen & $\mathrm{C} 1: 2(7 \%)$ & C1: NR & C1: NR \\
\hline & C2: placebo & C2: $2(10 \%)$ & C2: NR & C2: NR \\
\hline & & Total: $5(6 \%)$ & Total: NR & \\
\hline \multirow[t]{3}{*}{$\begin{array}{l}\text { Wuttke 2003/ } \\
2006 a / 2006 b\end{array}$} & I1: black cohosh & I1: $0(0 \%)$ & I1: NR & $\begin{array}{l}\text { I1: vaginal spotting } \\
(3,15 \%) \text {, vertigo }(1, \\
5 \%) \text {, hypertension } \\
(1,5 \%) \text {, headache } \\
(1,5 \%) \text {, bronchitis } \\
(1,5 \%) \text {, rhinitis }(1, \\
5 \%) \text {, viral infection } \\
(1,5 \%)\end{array}$ \\
\hline & $\begin{array}{l}\mathrm{C} 1 \text { : conjugated oe- } \\
\text { strogens }\end{array}$ & C1: $0(0 \%)$ & C1: NR & $\begin{array}{l}\text { C1: bronchitis }(2 \text {, } \\
9 \%) \text {, toothache }(2 \text {, } \\
9 \%) \text {, vaginal spot- } \\
\text { ting }(1,5 \%) \text {, diar- } \\
\text { rhoea }(1,5 \%) \text {, der- } \\
\text { matitis }(1,5 \%) \text {, vi- } \\
\text { ral infection }(1,5 \%) \\
\text {, elevated ALT }(1 \text {, } \\
5 \%)\end{array}$ \\
\hline & C2: placebo & C2: $0(0 \%)$ & C2: NR & $\begin{array}{l}\text { C2: vaginal spotting } \\
\begin{array}{l}(2, \quad 10 \%), \\
\text { glycaemia }(1, \quad 5 \%) \\
\text {, arthritis }(1,5 \%)\end{array}\end{array}$ \\
\hline
\end{tabular}


Table 6. Adverse effects B

(Continued)

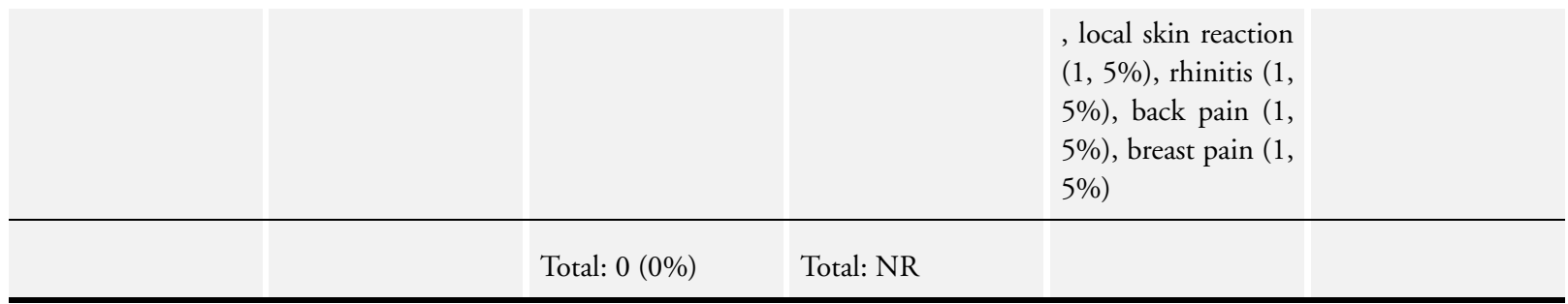

C: control; GI: gastrointestinal; I: intervention; MDP: medroxyprogesterone; NR: not recorded.

\section{A P P E N D I C E S}

\section{Appendix I. AARP Ageline search strategy}

1. Cimicifuga.tw

2. Actaea.tw

3. Ranunculaceae.tw

4. Black cohosh.tw

5. Rattleweed.tw

6. Snakeroot.tw

7. Bugbane.tw

8. Wanzenkraut.tw

9. Remifemin.tw

10. OR 1-9

11. Menopause.tw

12. Climacteric.tw

13. Premenopause.tw

14. Perimenopause.tw

15. Postmenopause.tw

16. Vasomotor symptom.tw

17. Sweating.tw

18. Hot flash.tw

19. Hot flush.tw

20. Dyspareunia.tw

21. Vaginal dryness.tw

22. Urogenital symptom.tw

23. Libido.tw

24. Irritabilty.tw

25. Insomnia.tw

26. Bones.tw

27. Quality of life.tw

28. OR 11-27

29. prospective study.tw

30. clinical trial.tw

31. randomized controlled trial.tw

Black cohosh (Cimicifuga spp.) for menopausal symptoms (Review)

Copyright ( 2012 The Cochrane Collaboration. Published by John Wiley \& Sons, Ltd. 
32. randomized clinical trial.tw

33. controlled clinical trial.tw

34. double-blind.tw

35. single-blind.tw

36. OR 29-35

37. 10 AND 28 AND 36

\section{Appendix 2. AMED search strategy}

1. exp climacteric/ or exp menopause/ or exp postmenopause/

2. menopaus\$.mp.

3. perimenopaus\$.mp.

4. postmenopaus\$.mp

5. climacteric.mp.

6. or/ $1-5$

7. (hot flash\$ or hot flush\$).mp.

8. vasomotor symptom $\$ . m p$.

9. night sweat\$.mp.

10. vaginal atrophy.mp.

11. vagina $\$$ dry $\$ . m p$.

12. bone $\$ . m p$.

13. libido.mp.

14. exp "Quality of Life"/

15. (Quality of Life).mp.

16. or/7-15

17. exp Cimicifuga/

20. Cimicifuga.mp.

21. black cohosh.tw.

22. ranunculaceae.mp.

23. actaea.mp.

24. (rattleweed or snakeroot).mp.

25. (bugbane or wanzenkraut).mp.

26. remifemin.mp.

27. or/19-26

28. 4 and 18 and 27

\section{Appendix 3. Australian Medical Index (AMI) search strategy}

1. Cimicifuga.tw

2. Actaea.tw

3. Ranunculaceae.tw

4. Black cohosh.tw

5. Rattleweed.tw

6. Snakeroot.tw

7. Bugbane.tw

8. Wanzenkraut.tw

9. Remifemin.tw

10. OR 1-9

11. Menopause.tw

12. Climacteric.tw

13. Premenopause.tw

14. Perimenopause.tw

Black cohosh (Cimicifuga spp.) for menopausal symptoms (Review)

Copyright $\odot 2012$ The Cochrane Collaboration. Published by John Wiley \& Sons, Ltd. 
15. Postmenopause.tw

16. Vasomotor symptom.tw

17. Sweating.tw

18. Hot flash.tw

19. Hot flush.tw

20. Dyspareunia.tw

21. Vaginal dryness.tw

22. Urogenital symptom.tw

23. Libido.tw

24. Irritabilty.tw

25. Insomnia.tw

26. Bones.tw

27. Quality of life.tw

28. OR 11-27

29. prospective study.tw

30. clinical trial.tw

31. randomized controlled trial.tw

32. randomized clinical trial.tw

33. controlled clinical trial.tw

34. double-blind.tw

35. single-blind.tw

36. OR 29-35

37. 10 AND 28 AND 36

\section{Appendix 4. BioMed Central Gateway search strategy}

1. Cimicifuga.tw

2. Actaea.tw

3. Ranunculaceae.tw

4. Black cohosh.tw

5. Rattleweed.tw

6. Snakeroot.tw

7. Bugbane.tw

8. Wanzenkraut.tw

9. Remifemin.tw

10. OR 1-9

11. Menopause.tw

12. Climacteric.tw

13. Premenopause.tw

14. Perimenopause.tw

15. Postmenopause.tw

16. Vasomotor symptom.tw

17. Sweating.tw

18. Hot flash.tw

19. Hot flush.tw

20. Dyspareunia.tw

21. Vaginal dryness.tw

22. Urogenital symptom.tw

23. Libido.tw

24. Irritabilty.tw

25. Insomnia.tw

26. Bones.tw

Black cohosh (Cimicifuga spp.) for menopausal symptoms (Review)

Copyright $\odot 2012$ The Cochrane Collaboration. Published by John Wiley \& Sons, Ltd. 
27. Quality of life.tw

28. OR 11-27

29. prospective study.tw

30. clinical trial.tw

31. randomized controlled trial.tw

32. randomized clinical trial.tw

33. controlled clinical trial.tw

34. double-blind.tw

35. single-blind.tw

36. OR 29-35

37. 10 AND 28 AND 36

\section{Appendix 5. CAM on PubMed search strategy}

1. Cimicifuga.tw

2. Actaea.tw

3. Ranunculaceae.tw

4. Black cohosh.tw

5. Rattleweed.tw

6. Snakeroot.tw

7. Bugbane.tw

8. Wanzenkraut.tw

9. Remifemin.tw

10. OR 1-9

11. Menopause.tw

12. Climacteric.tw

13. Premenopause.tw

14. Perimenopause.tw

15. Postmenopause.tw

16. Vasomotor symptom.tw

17. Sweating.tw

18. Hot flash.tw

19. Hot flush.tw

20. Dyspareunia.tw

21. Vaginal dryness.tw

22. Urogenital symptom.tw

23. Libido.tw

24. Irritabilty.tw

25. Insomnia.tw

26. Bones.tw

27. Quality of life.tw

28. OR 11-27

29. prospective study.tw

30. clinical trial.tw

31. randomized controlled trial.tw

32. randomized clinical trial.tw

33. controlled clinical trial.tw

34. double-blind.tw

35. single-blind.tw

36. OR 29-35

37. 10 AND 28 AND 36

Black cohosh (Cimicifuga spp.) for menopausal symptoms (Review) 


\section{Appendix 6. CENTRAL search strategy}

1. exp climacteric/ or exp menopause/ or exp menopause, premature/ or exp perimenopause/ or exp postmenopause/

2. (menopaus\$ or perimenopaus\$).tw.

3. postmenopaus\$.mp. or climacteric.tw. [mp = title, original title, abstract, mesh headings, heading words, keyword]

4. or/1-3

5. exp Hot Flashes/

6. (hot flash\$ or hot flush\$).tw.

7. (vasomotor adj5 symptom\$).tw.

8. (nocturnal adj5 diaphoresis).tw.

9. climateric.tw.

10. (vagina $\$$ adj3 atrop\$).tw.

11. (vagina $\$$ adj3 dry $\$$ ).tw.

12. (night adj3 sweat\$).tw.

13. bone\$.tw.

14. exp Libido/

15. libido.tw.

16. exp "Quality of Life"/

17. (Quality adj3 Life).tw.

18. or/5-17

19. exp Cimicifuga/

20. Cimicifuga.tw.

21. black cohosh.tw.

22. exp ranunculaceae/ or exp actaea/

23. (ranunculaceae or actaea).tw.

24. (rattleweed or snakeroot).tw.

25. (bugbane or wanzenkraut).tw.

26. remifemin.tw.

27. or/19-26

28. 4 and 18 and 27

\section{Appendix 7. CINAHL search strategy}

1. exp climacteric/ or exp menopause/ or exp menopause, premature/ or exp perimenopause/ or exp postmenopause/

2. (menopaus $\$$ or perimenopaus $\$$ ).tw.

3. postmenopaus\$.mp. or climacteric.tw. [ $\mathrm{mp}=$ title, subject heading word, abstract, instrumentation]

4. or/1-3

5. exp Hot Flashes/

6. (hot flash\$ or hot flush\$).tw.

7. (vasomotor adj5 symptom $\$$ ).tw.

8. (nocturnal adj5 diaphoresis).tw.

9. climateric.tw.

10. (vagina $\$$ adj3 atrop\$).tw.

11. (vagina $\$$ adj3 dry $\$$ ).tw.

12. (night adj3 sweat\$).tw.

13. bone\$.tw.

14. exp Libido/

15. libido.tw.

16. exp "Quality of Life"/

17. (Quality adj3 Life).tw.

18. or $/ 5-17$

19. exp Cimicifuga/

20. Cimicifuga.tw.

Black cohosh (Cimicifuga spp.) for menopausal symptoms (Review)

Copyright ( 2012 The Cochrane Collaboration. Published by John Wiley \& Sons, Ltd. 
21. black cohosh.tw.

22. exp ranunculaceae/ or exp actaea/

23. (ranunculaceae or actaea).tw.

24. (rattleweed or snakeroot).tw.

25. (bugbane or wanzenkraut).tw.

26. remifemin.tw.

27. or/19-26

28. 4 and 18 and 27

\section{Appendix 8. Dissertations Abstracts International search strategy}

1. Cimicifuga.tw

2. Actaea.tw

3. Ranunculaceae.tw

4. Black cohosh.tw

5. Rattleweed.tw

6. Snakeroot.tw

7. Bugbane.tw

8. Wanzenkraut.tw

9. Remifemin.tw

10. OR 1-9

11. Menopause.tw

12. Climacteric.tw

13. Premenopause.tw

14. Perimenopause.tw

15. Postmenopause.tw

16. Vasomotor symptom.tw

17. Sweating.tw

18. Hot flash.tw

19. Hot flush.tw

20. Dyspareunia.tw

21. Vaginal dryness.tw

22. Urogenital symptom.tw

23. Libido.tw

24. Irritabilty.tw

25. Insomnia.tw

26. Bones.tw

27. Quality of life.tw

28. OR 11-27

29. prospective study.tw

30. clinical trial.tw

31. randomized controlled trial.tw

32. randomized clinical trial.tw

33. controlled clinical trial.tw

34. double-blind.tw

35. single-blind.tw

36. OR 29-35

37. 10 AND 28 AND 36

38. Limit to dissertations and theses

Black cohosh (Cimicifuga spp.) for menopausal symptoms (Review) 


\section{Appendix 9. EMBASE search strategy}

1. exp "menopause and climacterium"/ or exp climacterium/ or exp early menopause/ or exp menopause/ or exp postmenopause/

2. (menopaus\$ or climacter\$).tw.

3. (postmenopaus $\$$ or perimenopaus $\$$ ).tw.

4. or/1-3

5. exp hot flush/ or exp night sweat/

6. (hot flash\$ or hot flush\$).tw.

7. (vasomotor adj5 symptom\$).tw.

8. (nocturnal adj5 diaphoresis).tw.

9. (night\$ adj5 sweat\$).tw.

10. climater\$.tw.

11. (vagina $\$$ adj3 atrop\$).tw.

12. (vagina $\$$ adj3 dry $\$$ ).tw.

13. bone\$.tw.

14. exp Libido/

15. libido.tw.

16. exp "quality of life"/

17. (Quality adj3 Life).tw.

18. or/5-17

19. exp CIMICIFUGA RACEMOSA/ or exp CIMICIFUGA/ or exp CIMICIFUGA RACEMOSA EXTRACT/

20. Cimicifuga.tw.

21. black cohosh.tw.

22. exp RANUNCULACEAE/

23. (ranunculaceae or actaea).tw.

24. (rattleweed or snakeroot).tw.

25. (bugbane or wanzenkraut).tw.

26. remifemin.tw.

27. or/19-26

28. Controlled study/ or randomized controlled trial/

29. double blind procedure/

30. single blind procedure/

31. crossover procedure/

32. drug comparison/

33. placebo/

34. random \$.ti,ab,hw,tn, mf.

35. latin square.ti,ab,hw,tn, mf.

36. crossover.ti,ab,hw,tn, mf.

37. cross-over.ti,ab,hw,tn, mf.

38. placebo\$.ti,ab,hw,tn, mf.

39. ((doubl\$ or singl\$ or tripl\$ or trebl\$) adj5 (blind\$ or mask\$)).ti,ab,hw,tn,mf. (113655)

40. (comparative adj5 trial\$).ti,ab,hw,tn, mf.

41. (clinical adj5 trial\$).ti,ab,hw,tn,mf.

42. or/28-41

43. nonhuman/

44. animal/ not (human/ and animal/)

45. or/ $/ 43-44$

46.42 not 45

47. or $/ 28-46$

48. 4 and 18 and 27 and 47

Black cohosh (Cimicifuga spp.) for menopausal symptoms (Review) 
Appendix 10. Health Source Nursing/Academic edition search strategy

1. Cimicifuga.tw

2. Actaea.tw

3. Ranunculaceae.tw

4. Black cohosh.tw

5. Rattleweed.tw

6. Snakeroot.tw

7. Bugbane.tw

8. Wanzenkraut.tw

9. Remifemin.tw

10. OR 1-9

11. Menopause.tw

12. Climacteric.tw

13. Premenopause.tw

14. Perimenopause.tw

15. Postmenopause.tw

16. Vasomotor symptom.tw

17. Sweating.tw

18. Hot flash.tw

19. Hot flush.tw

20. Dyspareunia.tw

21. Vaginal dryness.tw

22. Urogenital symptom.tw

23. Libido.tw

24. Irritabilty.tw

25. Insomnia.tw

26. Bones.tw

27. Quality of life.tw

28. OR 11-27

29. prospective study.tw

30. clinical trial.tw

31. randomized controlled trial.tw

32. randomized clinical trial.tw

33. controlled clinical trial.tw

34. double-blind.tw

35. single-blind.tw

36. OR 29-35

37. 10 AND 28 AND 36

\section{Appendix I I. International Pharmaceutical Abstracts search strategy}

1. Cimicifuga.tw

2. Actaea.tw

3. Ranunculaceae.tw

4. Black cohosh.tw

5. Rattleweed.tw

6. Snakeroot.tw

7. Bugbane.tw

8. Wanzenkraut.tw

9. Remifemin.tw

10. OR 1-9

11. Menopause.tw

Black cohosh (Cimicifuga spp.) for menopausal symptoms (Review)

Copyright $(2012$ The Cochrane Collaboration. Published by John Wiley \& Sons, Ltd. 
12. Climacteric.tw

13. Premenopause.tw

14. Perimenopause.tw

15. Postmenopause.tw

16. Vasomotor symptom.tw

17. Sweating.tw

18. Hot flash.tw

19. Hot flush.tw

20. Dyspareunia.tw

21. Vaginal dryness.tw

22. Urogenital symptom.tw

23. Libido.tw

24. Irritabilty.tw

25. Insomnia.tw

26. Bones.tw

27. Quality of life.tw

28. OR 11-27

29. prospective study.tw

30. clinical trial.tw

31. randomized controlled trial.tw

32. randomized clinical trial.tw

33. controlled clinical trial.tw

34. double-blind.tw

35. single-blind.tw

36. OR 29-35

37. 10 AND 28 AND 36

\section{Appendix I2. MEDLINE search strategy}

1. Menopause $[\mathrm{MeSH}]$

2. Menopause, premature $[\mathrm{MeSH}]$

3. Climacteric $[\mathrm{MeSH}]$

4. Premenopause $[\mathrm{MeSH}]$

5. Perimenopause $[\mathrm{MeSH}]$

6. Postmenopause [MeSH]

7. Vasomotor system [MeSH]

8. Sweating [MeSH]

9. Hot flashes [MeSH]

10. Hot flush $\$[\mathrm{tw}]$

11. Dyspareunia $[\mathrm{MeSH}]$

12. Vagina $[\mathrm{MeSH}]$

13. Vaginal dryness [tw]

14. Urogenital system [MeSH]

15. Libido $[\mathrm{MeSH}]$

16. Irritability [tw]

17. Insomnia [tw]

18. Bone and bones $[\mathrm{MeSH}]$

19. Quality of life $[\mathrm{MeSH}]$

20. OR 1-19

21. Cimicifuga[MeSH]

22. Actaea $[\mathrm{MeSH}]$

23. Ranunculaceae $[\mathrm{MeSH}]$

Black cohosh (Cimicifuga spp.) for menopausal symptoms (Review)

Copyright ( 2012 The Cochrane Collaboration. Published by John Wiley \& Sons, Ltd. 


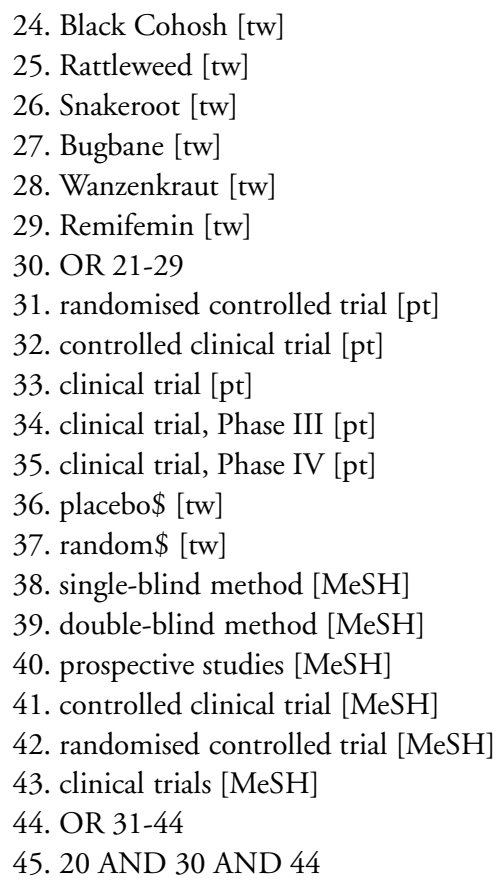

\section{Appendix 13. Natural Medicines Comprehensive Database search strategy}

1. Cimicifuga (subject heading)

\section{Appendix I4. PsycINFO search strategy}

1. Cimicifuga.tw

2. Actaea.tw

3. Ranunculaceae.tw

4. Black cohosh.tw

5. Rattleweed.tw

6. Snakeroot.tw

7. Bugbane.tw

8. Wanzenkraut.tw

9. Remifemin.tw

10. OR 1-9

11. Menopause.tw

12. Climacteric.tw

13. Premenopause.tw

14. Perimenopause.tw

15. Postmenopause.tw

16. Vasomotor symptom.tw

17. Sweating.tw

18. Hot flash.tw

19. Hot flush.tw

20. Dyspareunia.tw

21. Vaginal dryness.tw

22. Urogenital symptom.tw

23. Libido.tw

Black cohosh (Cimicifuga spp.) for menopausal symptoms (Review)

Copyright ( 2012 The Cochrane Collaboration. Published by John Wiley \& Sons, Ltd. 
24. Irritabilty.tw

25. Insomnia.tw

26. Bones.tw

27. Quality of life.tw

28. OR 11-27

29. prospective study.tw

30. clinical trial.tw

31. randomized controlled trial.tw

32. randomized clinical trial.tw

33. controlled clinical trial.tw

34. double-blind.tw

35. single-blind.tw

36. OR 29-35

37. 10 AND 28 AND 36

\section{Appendix I5. Turning Research Into Practice (TRIP) search strategy}

1. Cimicifuga.tw

2. Actaea.tw

3. Ranunculaceae.tw

4. Black cohosh.tw

5. Rattleweed.tw

6. Snakeroot.tw

7. Bugbane.tw

8. Wanzenkraut.tw

9. Remifemin.tw

10. OR 1-9

11. Menopause.tw

12. Climacteric.tw

13. Premenopause.tw

14. Perimenopause.tw

15. Postmenopause.tw

16. Vasomotor symptom.tw

17. Sweating.tw

18. Hot flash.tw

19. Hot flush.tw

20. Dyspareunia.tw

21. Vaginal dryness.tw

22. Urogenital symptom.tw

23. Libido.tw

24. Irritabilty.tw

25. Insomnia.tw

26. Bones.tw

27. Quality of life.tw

28. OR 11-27

29. prospective study.tw

30. clinical trial.tw

31. randomized controlled trial.tw

32. randomized clinical trial.tw

33. controlled clinical trial.tw

34. double-blind.tw

35. single-blind.tw

Black cohosh (Cimicifuga spp.) for menopausal symptoms (Review)

Copyright ( 2012 The Cochrane Collaboration. Published by John Wiley \& Sons, Ltd. 
36. OR 29-35

37. 10 AND 28 AND 36

\section{H I S T O R Y}

Protocol first published: Issue 3, 2008

Review first published: Issue 9, 2012

\begin{tabular}{ll|l} 
Date & Event & Description \\
\hline 11 September 2007 & New citation required and major changes & Substantive amendment
\end{tabular}

\section{CONTRIBUTIONSOFAUTHORS}

Matthew Leach: protocol draft, search strategy development, acquisition of trial copies, trial selection, data extraction, data analysis, data interpretation, review draft and update draft.

Vivienne Moore: protocol draft, search strategy development, trial selection, data extraction, data interpretation and review draft.

\section{DECLARATIONSOF INTEREST}

The review authors have no competing interests to declare.

\section{SOURCES OF SUPPORT}

\section{Internal sources}

- No sources of support supplied

\section{External sources}

- MDSG, New Zealand.

\section{DIFFERENCES BETWEEN PROTOCOLANDREVIEW}

There are no differences between the original protocol and full review. 


\section{INDEX TERMS}

\section{Medical Subject Headings (MeSH)}

${ }^{*}$ Cimicifuga [adverse effects]; Dehydration [drug therapy]; Hot Flashes [drug therapy]; Perimenopause [* ${ }^{*}$ drug effects]; Phytotherapy [adverse effects; ${ }^{*}$ methods]; Postmenopause [ ${ }^{*}$ drug effects]; Randomized Controlled Trials as Topic; Sweating [drug effects]; Trifolium; Vaginal Diseases [drug therapy]

\section{MeSH check words}

Female; Humans; Middle Aged 